


$$
\frac{246}{11-9-85}
$$

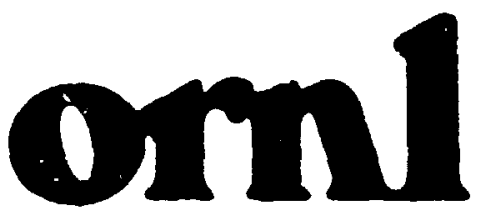

OAK
RIDGE NATIONAL LABORATORY

UNION

CARBIDE

$\boldsymbol{J}$

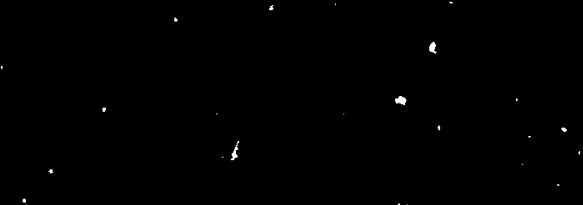

1
Dr. 2017

ORNL-5688

\section{DUVAS (Derivative UV-Absorption Spectrometer): Instrument Description and Operating Manual}
A. R. Hawthorne
J. M. Dougherty
C. E. Metcalfe

OPERATED BY

UNION. CARBIOE CORPORATION FOR THE UNITED STAIES

DEPARTMENT OF ENERGY

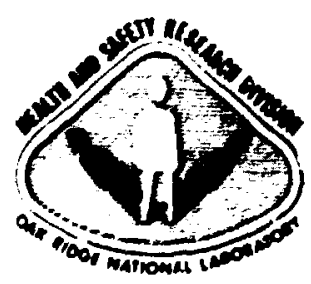

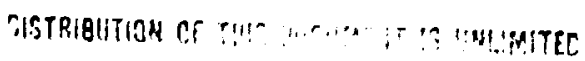


ORNL-5688

Dist. Category UC-41

Contract No. W-7405-eng-26

Health and Safety Research Division

DUVAS (Derivative UV-Absorption Spectrometcr):

INSTRUMENT DESCRIPTION AND OPERAIING MANUAL

A. R. Hzwthorre

J. :?. Dougherty*

c. E. Meccalfe

* Computer Sciences Division

Date Published: November 1980

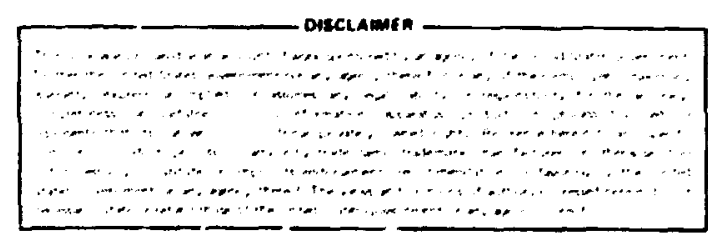

OAK RIDGE NATIONAL LABORATORY

Oak Ridge, Tennessee 37830

operaced by

UNION CARBIDE CORPORATION

for the

DEPARTMENT OF ENERGY

DistmiBurion of rim: : : : 
TABLE OF CONTENTS

$\underline{\text { Page }}$

LIST OF FIGURES .... . . . . . . . . . . . . . v

LIST OF TAELES ........................ vii

PRETACE .......................... ix

ABSTRACT ....................... $x$

INTRODUCTION ............................. 1

THEORY ........................ 4

INSTRUMENTATION ............................ II

Optics............................ 14

fleccronics ........................ 15

Microcomputer .................. . . . 18

EVALUATION . . . . . . . . . . . . . . . . . 24

APPLICATIONS . . . . . . . . . . . . . . 33

FlTURE WORK ....................... 41

CONCLUSICI . . . . . . . . . . . . . . . 43

ACKNOWLEDGMENTS . . . . . . . . . . . . . . 45

REFERENCES ....................... 47

AppendiX A. LIBRARY OF SECOND-DERIVATE SPECTRA . . . . . . . 49

AppendiY B. DUVAS PROGRIM LISTING . . . . . . . . . . 59

Appendix C. ELECTRONIC SCHEMATIC FOR DUVAS . . . . . . . 111

Appendix D. PARTIAL PARTS LIST FOR PROTOTYPE DUVAS . . . . 115 


\section{LIST OE EIGURES}

Figure

Fage

1 Illustration of second-derivative enhancenent of nair:w peaks and suppression of broad peaks . . . . . . . .

2 Superposition of the two peaks shown in Fig. : with :-:e narrow peak shifted 2 nm to the right and oniy $10 z$ a intense as the broad peak to illustrate increised selectivity of second derivative ............. 5

3 Spectra oí phenol in water $(10 \mathrm{\mu g} / \mathrm{mL})$ showirg al =ecabsorption spectrum and second-derivative spectri obtained by various techniques ............ .47

4 Photograph of the Lear Siegler SH400 derivative spectrometer ...................

5 optical schematic of the SM400 derivacive spectrocici. showing both the vapor phase cell and Iiqutd rell modes of operation ................... 12

6 Photograph of the prototype DUVhS with $0.5-m$ sampling cej.1....................

7 Inside view of monochromator showing smaj $\mathrm{i}$ vibra.ing mirror

8 Insfde view of DUVAS showing light source, wir th:omator, stepping motor, electronics, and power supil . . . . . 16

9 Block diagram of DUVAS electronics . . . . . . . . . 16

10 Block diagram of DUVAS signal prosessir.g, dii control circuits ....................

11 Photograph of single-board microcomput : thet

12 DUVAS spectrum displayed on the DECLAB i1,02 it:m

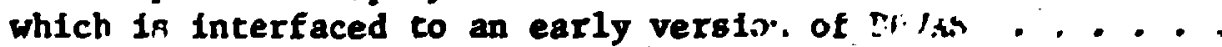

13 DUVAS with liquid sampling compartment atta ied and. Interf aced with the PET 2001 . . . . . . . . . . . . . 20

14 A typical vapor callbration curve fos biNAS cev:act...? using a dynamic flow system.... 
15 DUVAS response to a step increase in vapor concentration as $a$ function of $t / \tau$ were $\tau$ equals cell voluse divided by Elow rate ................. 26

16 Variatior of naphthalene and wethylnaphthalene vafor from a syotinoll saple illustrating the DUVS response co a step decrease and increase in concentration ..... 27

17 DUVAS spectrin of benzene vapor illustrating a Cypleal aromatic vapor spectrum ............. 28

18 Time spectrue cf benzene vapor monitored at tíe 254-nm peak showing equilit raticn aiter injection of $\therefore$ microsyringe of bentene into the closed samlixg cell.....

19 Liquid calibration standards for four PMA compounds in cyclohexane used to Illustrate selectivity ........ 31

20 Comparisou of least-squares $s^{-}=t r a l$ fit to experimental spectrun obtained with DCTAS ............. 32

21 Calibration curve generated using DUVAS for phenol in water ........................ 34

22 Normal (bottom) and second-derivative (top) spectra illustrating the effect of sample turbicitity on the analysis of phenol in a wastewater sample ......... 35

23 DUVAS calibration curve (bottcm: for low levels of $\mathrm{NH}_{3}$ csiag a 1-n sampling cell and 12-w pathlength and a standard spectrum at $100 \mathrm{ppb}$ (top) ......... 36

24 Spectrum of vapors from a low-Btu gasifler tar sample taken with DUVAS .................. 38

25 Specirum of room air becore and after a condensate vessel is opened taken with DUVAS ............. 39

26 Plot of benzene cuncentration versus time near a lock-hopper knife valve as measured by DUVAS . . . . . . 40 


\section{IIST OF TABLES}

Table 3

Page

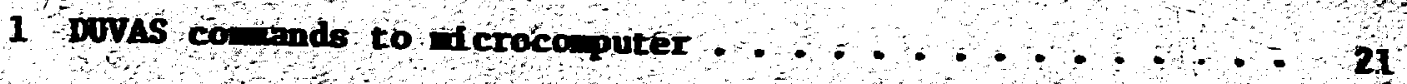

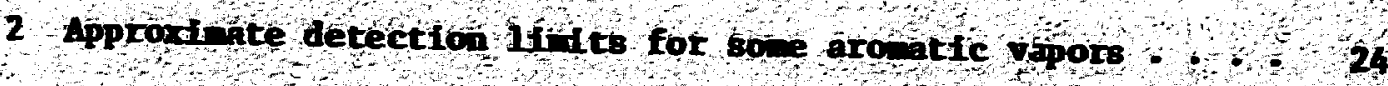

3 Least-squares analysis of a ixture of foor $P 4 A$ co pownds In Cycloheraine obtatned using derivative spectoptiy,,,,-- 37 


\section{PrERACE}

This report is intended to serve as an operating ranual and to provide background inficmation and application exâples for readers with a general interest in Duvas. The sections on Instrumentation and Baluation, along ofth the Appendices, are of greatest interest to the Instruent user. These sectlons add considerable detall and way be deephasized by the reater who 18 only interested in the general subject of derlvative epectro detry. 
DUVAS (Derivative UV-Absorption Spectrometer): INSTRUAENT DESCRIPTIOH AND OPERATINS MANUAT

A. R. Hawthorne, J. M. Dougherty, and C. E. Metcalfe

ABSTRACT

DUVAS is a real-time, field-portable spectrometer capable of monitoring a variet, of aromatic organic vapors and inorganic gases at sub-ppm concentrations. The instrument is a prototype, wicrocomputercontrolled, derivative ultraviolet (UV; absorption spectrometer (DUVAS) developed primarily for area monitoring at coal conversion facilities, although other important occupational and environnental monitoring applications for compounds such as $\mathrm{SO}_{2}, \mathrm{NO}_{x}, \mathrm{NH}_{3}, 2$ HCHO are also being pursued: :

The first section of this report outlines the theory of derivative spectrometry, discusses various methods of obtaining derivative spectra, and presencs the principles on which DUVAS is based. The second section details the instrumentation, both hardware and software, used to implement this prototype DUVAS, while the third section provides details of various evaluation parameters and procedures. Detailed appendices are included showing schematic drawings, perts lists, program listings, and library spectra. The final section gives specific application examples including analysis of real samples in the laboratory and results obtained during field tests.

Further improvements and modifications are under development which will lower the cost, increase the iustrument capability, and reduce the size ald weight of the instrument. The DUVAS described in this report constitutes a useful addition to the monitoring instruments ava+lable to the industrial hygienist and environmental scientist in evaluating the exposure of man and the environment to these potentially hazardous compounds. 


\section{INTRODUCTION}

Increasing emphasis during the past decade on the adverse health effects on man due to pollutants in both the work and the general environment, and wore recently the indoor environment, has neressitated the development of instrumentation suitable for monitoring low levels of many comounds. Several inportant features must be evaluated in characterizing an instrument for low level pollutant wonitoring. Among the more important features are:

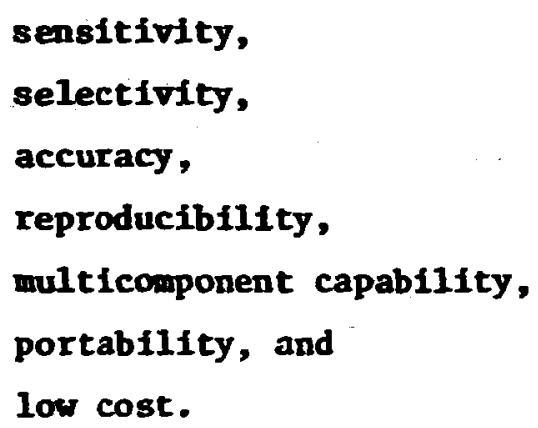

Trade-offs must of ten be considered among these various parameters. Ultraviolet (UV) absorption spectrometry is quite sensitive for detecting many important pollutant compounds. However, the technique often suffers from lack of selectivity between compounds. Secondderivative spectrometry offers a method of enhancing the sharp absorption bands of specific pollutants while suppressing the interferences from peaks of broad-band absorption. Second-derivative spectrometry has proven useful both as a method for qualitatively enhancing spectral data and as a means of improving quantitative analysis.1-19

This report describes a real-time, field-portable spectrometer capible of monitoring a variety of aromatic organic vapors and inorganic gases at sub-ppm concentrations. The instrument is a prototype, microcomputer-controlled, derivative UV-absorption spectrometer (DUVAS) developed primarily for area monitoring at coal conversion factilties, although other important occupational and environmental monitoring epplications for compounde such as $\mathrm{SO}_{2}, \mathrm{NO}_{\mathrm{x}}, \mathrm{O}_{3}, \mathrm{NH}_{3}$, and formaldehyde (HCHO) are also being pursued. 
Examples of important trace pollutant analysis areas where DUVAS has been evaluated, or shows potential application, include swokeplune wonitoring for $\mathrm{SO}_{2}, \mathrm{O}_{3}, \mathrm{NO}_{2}, \mathrm{NH}_{3}$, and nitrous acid (HONO). 19 This application requires an instrument that can provide real-tine measurement, good selectivi:y, high sensitivity, and ruggedness. Prelininary evaluation indicates that DUVAS can provide these features. In addition to having promise as a plume wonitor, DUVAS should prove a viable alternative to remote station woritoring with witiple instrunents for measuring criteria pollutants where a single instrument capable of measuring several pollutants is desirable.

A second area of potential application is indoor air quality seasurements. Recent increased awareness as to the potential inpact of indoor air quality on humon health, coupled with energy conservation measures wich tend to increase the levels of indoor pollutants, has highlighted the need for relatively simple and portable instrumentation to measure the levels of various indoor pollutants. 20 Among the compounds of interest that DUVAS can measire are $\mathrm{NO}_{\mathrm{x}}, \mathrm{NH}_{3}$, HCHO (and other aldehydes), plus various organic coupounds such as phenolics found in cigarette smoke. Although minimal work has been done in this area to date, future efforts are expected to increase.

A third area, and the prime wotivation for the development of DUVAS, is in industrial hygtene wonitoring of various arcmatic vapors. 18 Although primary emphasis has been placed un chal converston facilities, many other industrial applications would find need for such an aromatic vapor monitor. A considerable potential hazard exists in the cosl conversion industry where a wide range of toxic and carcinogenic materials are found in varfous proj:sct streans.21,22 Among the many conpounds present are benzene, toluene, phenol, cresols, and naphthalenes. These compounds have sufficient vapor pressures to generate concentrations of several ppm in the work area.23 Exposure to these and other polynuclear aromatic (PNA) compounds is most likely to occur during waintenance operations or in the event of equipmest leaks. A real-tiwe area monitor is needed to provide workers $w i t h$ information on organic conientrations in those areas where concentrations may vary with tine. Increased 
concentrations cf vapors from volatile compounds could also indicate a potential for increased exposure to nonvolatile PRAs. 24

A final application of DUVAS is in the analysis of liquid sapples, either in extracted solvents or direct!y in wastewater analysis. ${ }^{13}$ This area has not been elphasized as heavily as gas and vapor analysis but does offer potential as an on-line waste stream anaiyzer. The insensitivity of derivative spectrometry to saple turbidity is an advantage for this application.

This report is organizsd into four major sections. The first section outlines the theoify of derivative spectrometry, discusses various methods of obtaining derivative spectra, and presents the principles on which DUVAS is based. The seccnd section details the hardware and software instrumentation used to implement this prototype DUVAS, while the third section provides details of various evaluation parameters and procedurcs. The'se sections should provide the basic information needed to become familiar with the instrument's operation. The fourth section gives spec: fic application examples fncluding analysis of real samples in the laboratory and results obtained during field tests. References on derivative spectrometry are listed at the end of the text. Finally, appendices are included showing schematic drawings, parts lists, prcgram list; 'gs, and library spectra. These should prove useful for instrument repair and modification as well as for a general understanding of the instrument. 


\section{THECRY}

The lack of selectivity of UV-absorption techniques of ten prevents their use in the analysis of complex sampies without preliminary separation using some torm of chemi i fractionation such as chromatography. sacond-derivative spectrometr. ifers a methed of enhancing narrow absorption peaks while suppressing peaks of broad-band ajsorption thus improing seiectivity. Identification of indiridual spectra is also easier since for a particular compound the second-derivative spectrum usually contains more detailed structure than the direct spectrum.

Derivative absorption spectrometry has been used to enhance spectral features as well as to improve quantitative anal ysis of overlapping pcaks. The effect of enhanaing 'ne peak relative to another is fllustrated in Fig. 1, which shows that for peaks that are approximately Gaussian in shape, the peak height ratios are considerably different for the secund-derivative spectra than for the direct spectra. In the case of direct spectra, the ratio is 1.0 , while the ratio is 3.3 for the second-derivative spectra. Figire 2 illustrates the usefulness of the second-derivative procedure in resolving overlapping peaks. Consider the stimation of the peaks in Fig. 1 but with the narrow peak shifted $2 \mathrm{~nm}$ ard only $10 \%$ as intense as the broader peak. In the direct spectrum the small peak is not noticeable, while in the second-derivative soectrum the small peak is clearly visible on the side of the larger peak.

Methods of obtaining second-derivative spectra include numerical differentiation of direct spectra, electronic differentiation of the signal with respect to time, and, for optical systems, wavelength modulaticn of the source light using vibrating mirrors or oscillating altis followed by synchronous detection. ${ }^{3,6,8}$ Numerical differentiation requires the direct absorption spectra data to be in digital form. A computer program is then used to apply a finite-difference filter, with appropriate coefficients for the second derivative, in the direct spectrum. A itade-off is made between exact representation of the derivative and enhaucerient of signal-to-noise (S/N) in choosing filter widths. Until recently numerical cifferentfation was not practica: in a low cost, field instrument. Electronic differentiation 18 performed 

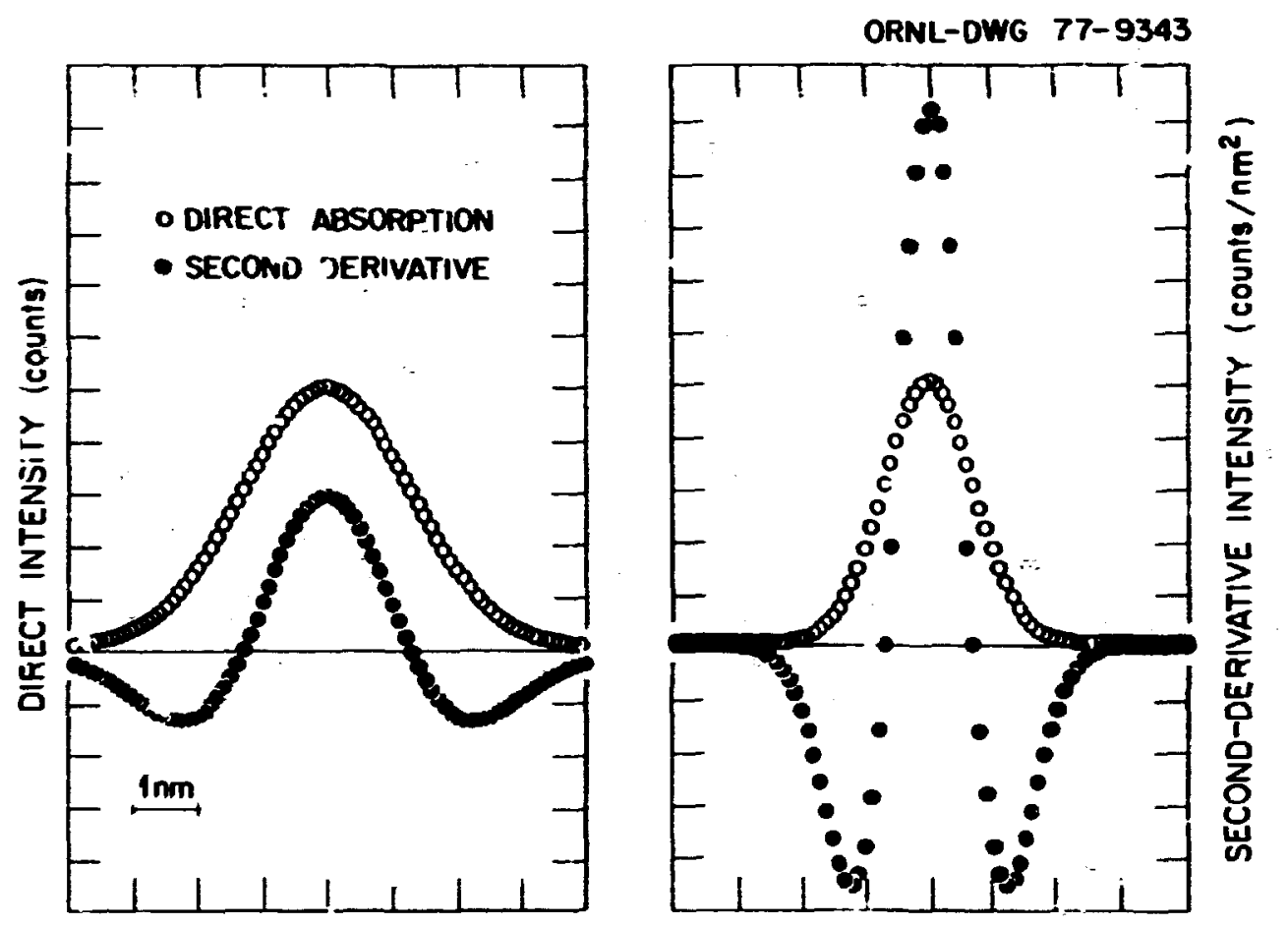

Fig. 1. Illustration of second-derivative enhancement of narrow peaks and suppressio. of broad peaks.

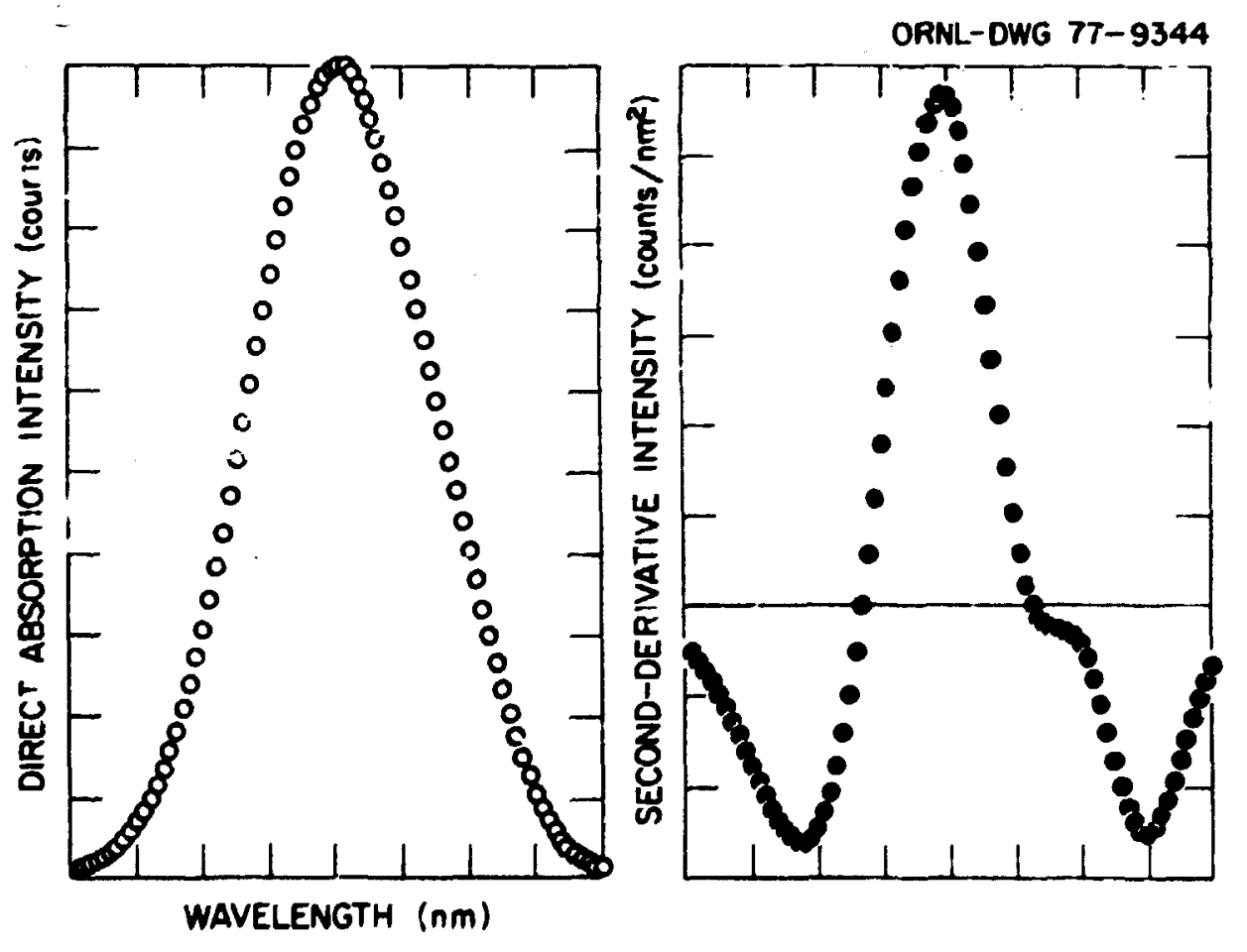

F1g. 2. Superposition of the two peaks shown in Fig. I with the narrow peak shifted $2 \mathrm{~nm}$ to the right and only $10 \%$ as fintense as the broad peak to illustrate increased selectivity of second derivative. 
by scanning through the spectrum at a constant race ( .e. $_{\mathrm{f}} \mathrm{d \lambda} / \mathrm{dt}=$ constant) and taking the time derivative of the direct analog signal using analog electronic circuits. The fast scanning rates requized to give large second-derivative signals utilize short time constants that tend to reduce the $S / K$ ratio, making a ialysis difficult for 10 concentrations. 14 Both numerical differentiation and electronic differentiation can be applied to a standard spectrophotometer without modification. A limitation of these techniques is that the seccid derivative at a specific wavelength can be found only by scannin; through that wavelength and not jy dwelli.ig at a fixed point. The seconó derivative of a spectrum can also be obtained by wavelength wodulating, by a few nanometers, the wavelength of the light going through the sample and detecting the second harmonic of the modulation frequency, which is proportional to the second derivative. Modulation is achieved by modification of the standard optical components of the spectrometer. Host often this modulatic $i$ is provided by a vibrating entrance or exit wonochromator silt, or an osillating mirror, to give a wavelength modulation with a frequency that is fast compared to the scanning rate. In contrast to the previousiy described methods of obtaining the second derivative, this techn-que will provide the second derivative at a stationary position, thus allowing continuous monitoring at a given wavelength. Also, since the gignal of interest is contained in the alternating current (ac) component with a frequency of twice the modulation frequency, the spectrometer can use an automat1c-gain-control (AGC) to maintain a constant direct current (dc) signal regardless of the sample absorptivity. This allows the eiectronic components of the system to operate in their optimm ranges. An example of each of the three methods of obtaining the second derivative of $a$ sample of phenol in water is shown in Fig. 3, along with the direct absorption spectrum.

The DUVAS 13 based on the technique of wavelength modulation of the Incident 1ight beam and detection of the second harmonic of the modulation, which is propertional to the second derivative of the absorption spectrum with respect to wavelength. This relationship can be show by expanding the Intensity distribution in a Taylor's serfes.? 

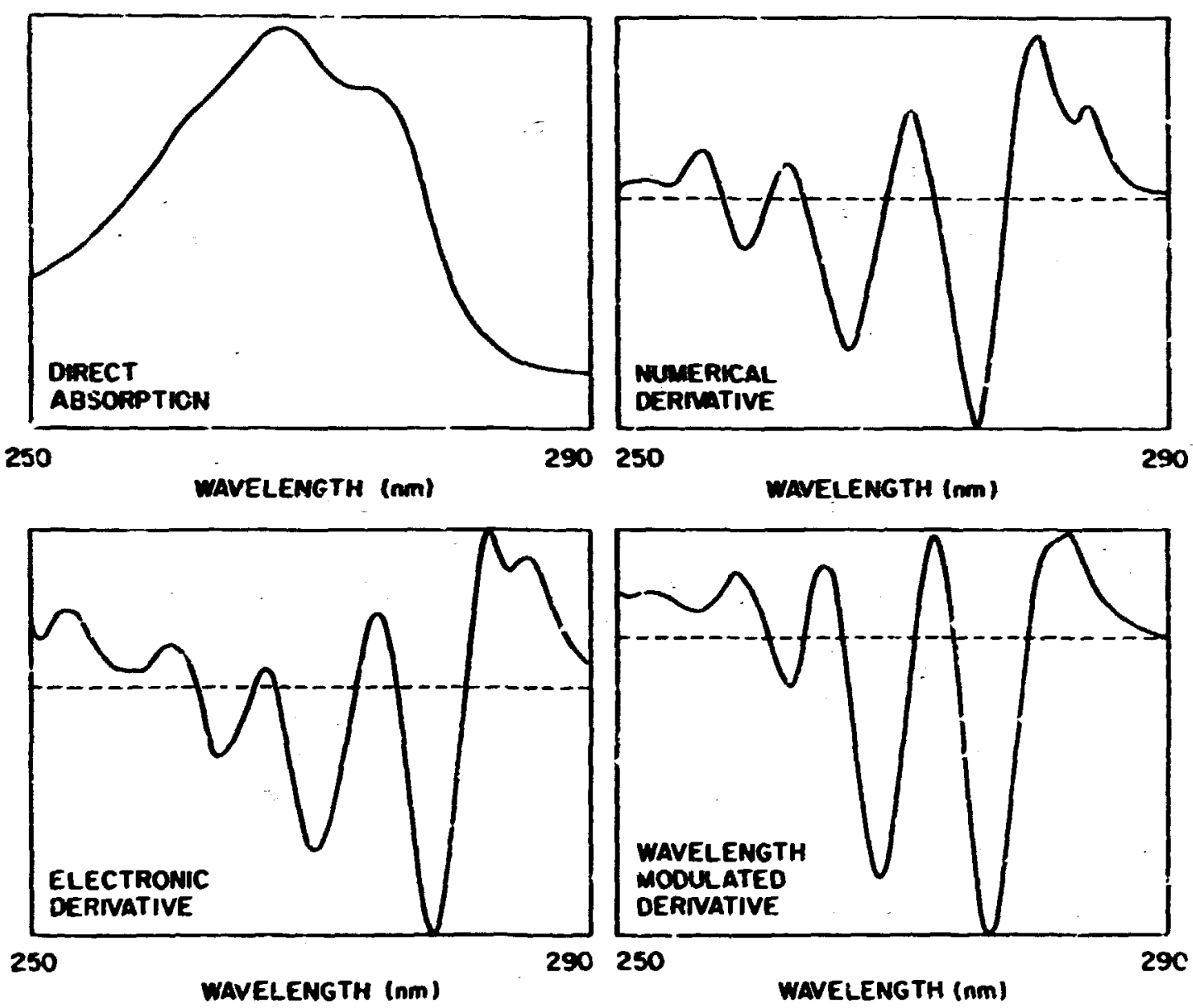

Fig. 3. Spectra of phenol in water $(10 \mu g / m L)$ showing direct: absorption spectrum and second-derivative spectra obtained by various techiıiques.

$$
I(\lambda)=I\left(\lambda_{0}\right)+\left.\left(-\lambda_{0}\right) \frac{\partial I(\lambda)}{\partial \lambda}\right|_{\lambda_{0}}+I /\left.2\left(\lambda-\lambda_{g}\right)^{2} \frac{\partial^{2} I(\lambda)}{\partial \lambda^{2}}\right|_{\lambda_{0}}+\ldots .
$$

The incident 1 ight at wavelength $\lambda_{0}$ is sinusoldally modulated with amplitude $\Delta \lambda$ and angular frequency $\omega$ :

$$
\lambda=\lambda_{0}+\Delta \lambda \sin \omega t .
$$

Combining Eqs. (1) and (2) ylelds:

$$
I(\lambda)=\sum_{n=0}^{\infty} \frac{\Delta \lambda^{n}}{n !} \sin ^{n} \text { wt } \frac{\partial^{n} I(\lambda)}{\partial \lambda^{n}}
$$


Using some motheratical identities, the first few terms of the series expansion can le written as follows:

$$
\begin{gathered}
I(\lambda) \quad I\left(\lambda_{0}\right)+1 /\left.4 \Delta \lambda^{2} \frac{\partial^{2}}{\partial \lambda^{2}}\right|_{\lambda_{0}}+\left.\Delta \lambda \sin \omega t \frac{\partial I(\lambda)}{\partial \lambda}\right|_{\lambda_{0}} \\
-1 /\left.4 \Delta \lambda^{2} \cos 2 \omega t \frac{\partial^{2} I(\lambda)}{\partial \lambda^{2}}\right|_{\lambda_{0}}+\ldots .
\end{gathered}
$$

As seen from Eq. (4), the intensity signal can be considered as composed of a dc term proportional to the direct absorption spectrum (provided $\Delta \lambda^{2}$ is sufficiently small), an ac telm of frequency w proportional to the first derivative, and an ac term of frequency $2 \omega$ proportional to the second derivative. If a complete expansion is performed, there are additional terms that contribute at the various frequencies, but they are usually quite small compared to the leading teim. 9 Demodulation of the $2 \omega$ term vields a signal proportional to the second derivative.

The relaifonship between the measured second-derivative response and the concentration of the analyte can be obtained assuming that Beer's iaw is applicable for that compound: 9

$$
\begin{aligned}
& I(\lambda)=I_{0}(\lambda) \exp [-b c \mu(\lambda)], \\
& \frac{\partial I(\lambda)}{\partial \lambda} / I(\lambda)=\frac{1}{I_{0}(\lambda)} \frac{\partial I_{0}(\lambda)}{\partial \lambda}-b c \frac{\partial \mu(\lambda)}{\partial \lambda},
\end{aligned}
$$

and

$$
\begin{aligned}
\frac{\partial^{2} I(\lambda)}{\partial \lambda^{2}} / I(\lambda)= & \frac{1}{I_{0}(\lambda)} \frac{\partial^{2} I_{0}(\lambda)}{\partial \lambda^{2}}-b c\left[\frac{\partial^{2} \mu(\lambda)}{\partial \lambda^{2}}\right. \\
& \left.+\frac{2}{I_{0}(\lambda)} \frac{\partial I_{0}(\lambda)}{\partial \lambda} \frac{\partial \mu(\lambda)}{\partial \lambda}+b c \frac{\partial \mu(\lambda)^{2}}{\partial \lambda}\right],
\end{aligned}
$$


where $I(\lambda)=$ transmitted intensity as a function of wavelength, $I_{0}(\lambda)=$ source intensity as a function of wavelength, $b=$ pathlength of 1 itht through the sample, $c$ = concentration of analyte in the sample, an $\mu(\lambda)=$ absorption coefficient as a function of wavelength. For small values of bc, the relationship between concentration and the secondderivative, notmalized by the direct spectrum response, of Ei- (7) is linear, as previously noted. However, a completely linezr resoonse can be obtained by subtraciing the square of the first-derivative response given by Eq. (6) from the second-derivative response given by Eq. (7). If this response is then corrected for contributions due to the spectral features of the $]$ ight source $\left[\partial I_{0}(\lambda) / \partial \lambda\right.$ and $\left.\partial^{2} I_{0}(\lambda) / \partial \lambda^{2}\right]$ by subtracting a blank sample in which bc equals zero, the following relationship is obtained between the concentration and the measured response, $R(b c)$ :

$$
R(b c)=-b c \frac{\partial^{2} \mu(\lambda)}{\partial \lambda^{2}}
$$

This desirable linear response allows measurement of high concentrations without the use of nonlinear analytical curves. If, instead of true firs:- and second-derivative responses, one has an infinite series response for the even and odd derivatives, as is the case for a wavelengthmodulated derivative spectrometer, the above analysis is not exact and a perfectly linear response is not obtained. However, the response of such an instrunent can be improved; the details are presented in ref. 11 . An alternative to performing the division required to normalize the derivative responses in Eq. (6) and Eq. (7) is to use the logarithm of Eq. (5). This procedure yields the following responses:

$$
\begin{aligned}
& F(\lambda) \equiv \ln I(\lambda)=\ln I_{0}(\lambda)-b c \mu(\lambda), \\
& \frac{\partial F}{\partial \lambda}=\frac{\partial \ln I_{0}(\lambda)}{\partial \lambda}-b c \frac{\partial \mu(\lambda)}{\partial \lambda}=\frac{1}{I_{0}(\lambda)} \frac{\partial I_{0}(\lambda)}{\partial \lambda}-b c \frac{\partial I 1(\lambda)}{\partial \lambda},
\end{aligned}
$$


and

$$
\begin{aligned}
\frac{\partial^{2} F}{\partial \lambda^{2}}= & \frac{\partial^{2} \ln I_{0}(\lambda)}{\partial \lambda^{2}}-b c \frac{\partial^{2} \mu(\lambda)}{\partial \lambda^{2}}=\frac{1}{I_{0}(\lambda)} \frac{\partial^{2} I_{0}(\lambda)}{\partial \lambda^{2}} \\
& -\frac{\partial I_{0}(\lambda)}{\partial \lambda} I_{0}(\lambda)-b c \frac{\partial^{2} \mu(\lambda)}{\partial \lambda^{2}}
\end{aligned}
$$

The prototyne DUVAS described in this report utilizes a iogarithaic amplifier instead of a divider circuit to pmvice the Jesired response.

For appications where bc $\mu(\lambda)$ is small, is often occurs in trace anilysis, or when the response is corrected for nonlinearity, 11 as just described, the data analysis can be performed using a least-squares niethod which utilizes standard spectra. This procedure as applied to derivative spectroscopy is discussed in ref. 12.

Anotiner advantage of the normalized second-derivative respense is that it is independent of sample opacity, light intensity fluctuations, and source-energy variations. The effect of long-term drift in the ? ight source $a r 1$ detector is greatly reduced. This advantag? is particulariy useful when no sample preparation to remove particulate matter is prirformed prior to analysis. 


\section{IUSTRUIDTATIOA}

Infitial notivation for the levelopment of a proto'-ype DUVAS developed fro the experinental evaluation of a Lear Siegler S:400 derivative spectrometer (FIg. 4). The protctype DUVAS : 35 designed to be smaller and substantially faster in spectru scaming compared to the cosmercially available :spectroweter. The si400 utilizes a 45-Hz oscillating "wobbler" (Fig. 5) to produce the vavelength sodulation. Also shown in Fig. 5 are the vapor phase cell and liquid cell nodes of operation. The prototype DWVAS ucilizes the sane type of sapling cells.

OPUL-PEOTO 5699-76

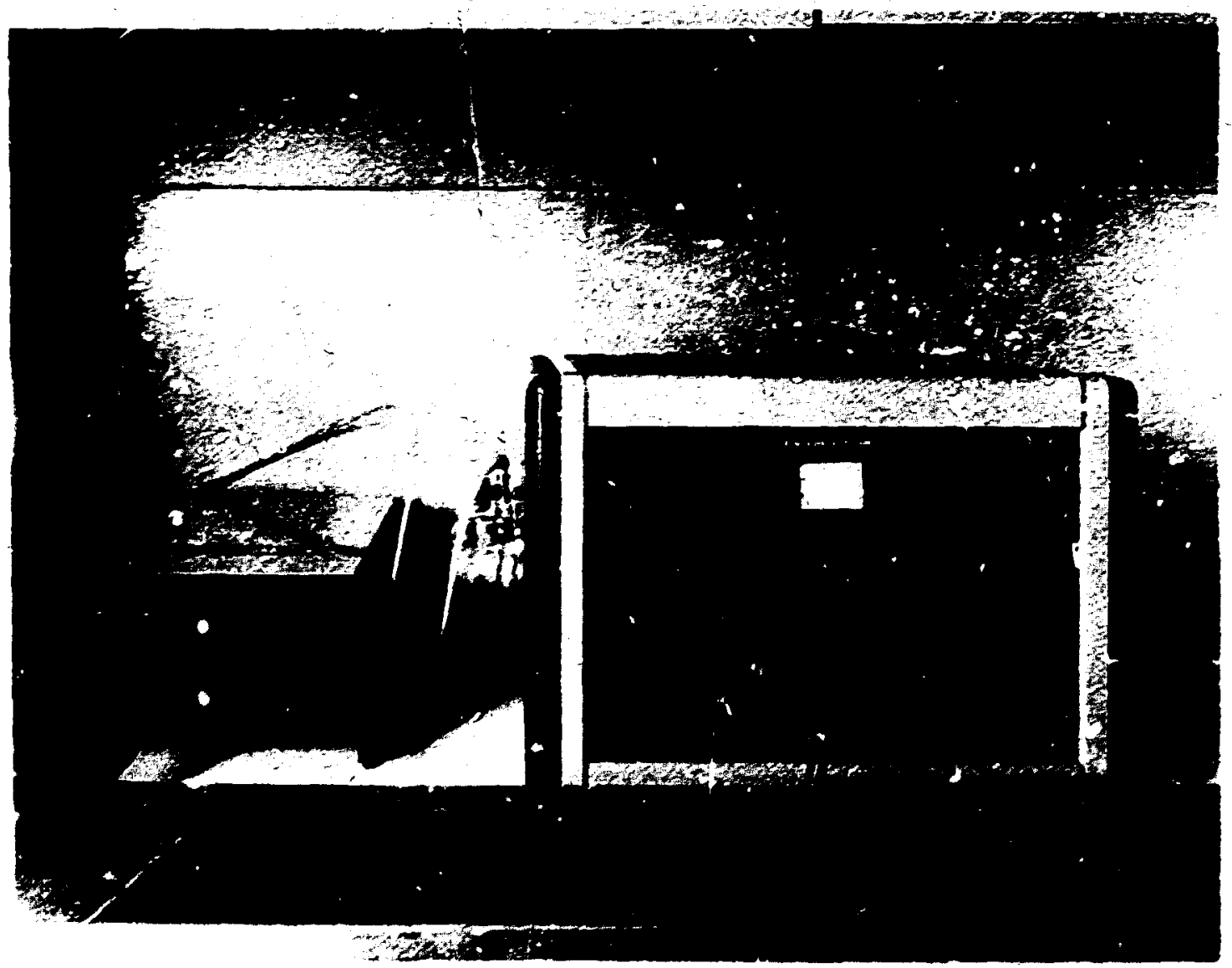

F1g. 4. Phorogra ih of the Lear StegJer \$4400 dertvative spectroweter. The 1-m multipass sampling sell is behtre the electronics nodule. 

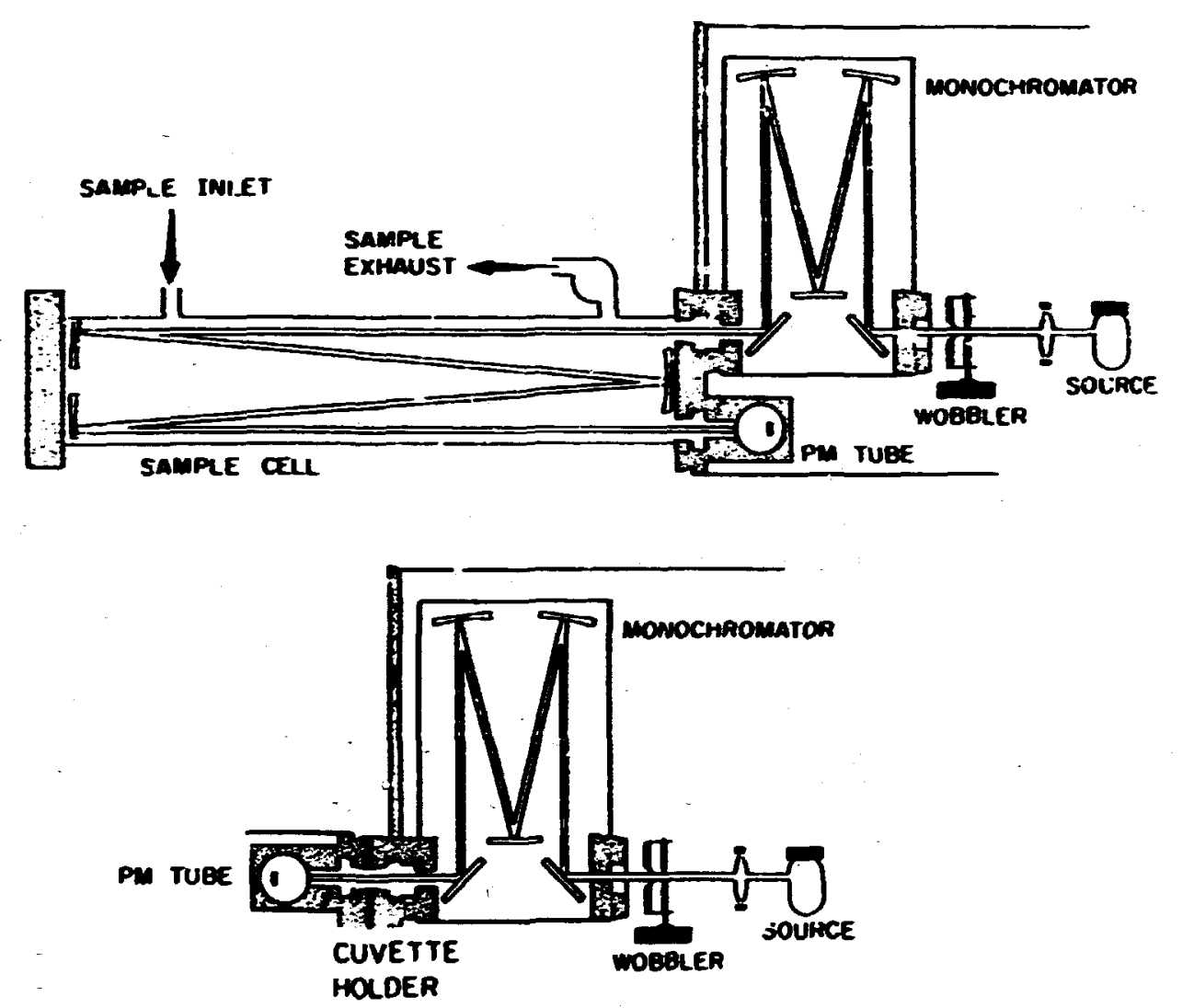

Fig. 5. Optical schematic of the SM400 derivative spectrometer showing both the vapor phase cell and liquid cell modes of operation.

A disadvantage of the slow modulation frequency of the SM400 is the long times required to scan a spectrum. There are only two scanning speeds of 2.5 and $10 \mathrm{~mm} / \mathrm{min}$. Scanning is provided by undirectional motors thus necessitating manual repositioning prior to each $8 \mathrm{can}$. The SM400 weighs about $60 \mathrm{~kg}$ and consists of two units: a control unit $51 \times 38 \times 61 \mathrm{~cm}$ and $a$ sample cell unit $147 \times 61 \times 23 \mathrm{~cm}$.

Several distinit improvements have been made in the microcomputercontrolled prototype DUVAS constructed at ORNL for field evaluation at various coal conversion facilities. The unit consists of a $32 \times 42 \times 18 \mathrm{~cm}$ box containing the electronics, microcomputer, monochromator, and Iight source. Attached to this box is a 0.5-m multipass sampling cell. The prototype DUVAS weighs approximately $15 \mathrm{~kg}$. Figure 6 is a photograph of the instrument. Other than power supplies, all controls are implemented through the micrccomputer key pad on top of the instrument. Appendices $C$ and D contain circuit schemata and a partial parts list. 


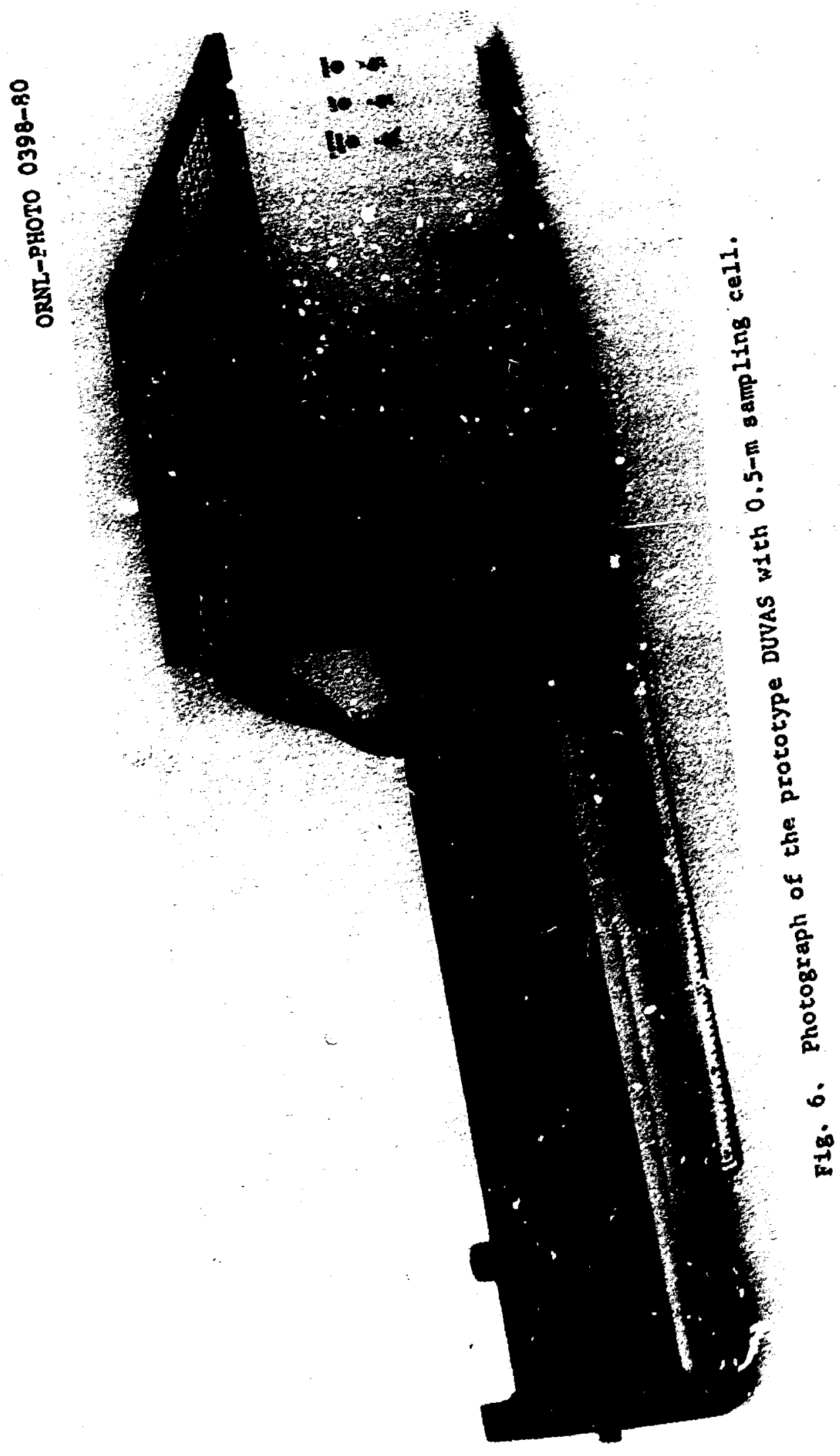


Optics

The optical components of DUVAS consist of a light source, monochromator, multipass sampling cell, and a photomultiplier tube (PAr). The light source is a $30-\mathrm{W}$ deuterium lamp providing continuous emission from $190 \mathrm{~nm}$ to $400 \mathrm{~mm}$.

The spectrometer monochromator is a swall 10-cm holographic grating with a resolution of $8 \mathrm{~mm} / \mathrm{mm}$. Wavelength wodulation is achíeved by replacing one of the mirrors in the wonochronator with a comercially available taut-band vibrator that uscillates with a frequency of $400 \mathrm{~Hz}$ (Fig. 7). The second harmonic signal at $800 \mathrm{~Hz}$ is sufficiently rewoved from the 120-izz line voltage to allow good filtering, thus fimroving the noise characteristics.

ODAL-PHOTO 5226-79

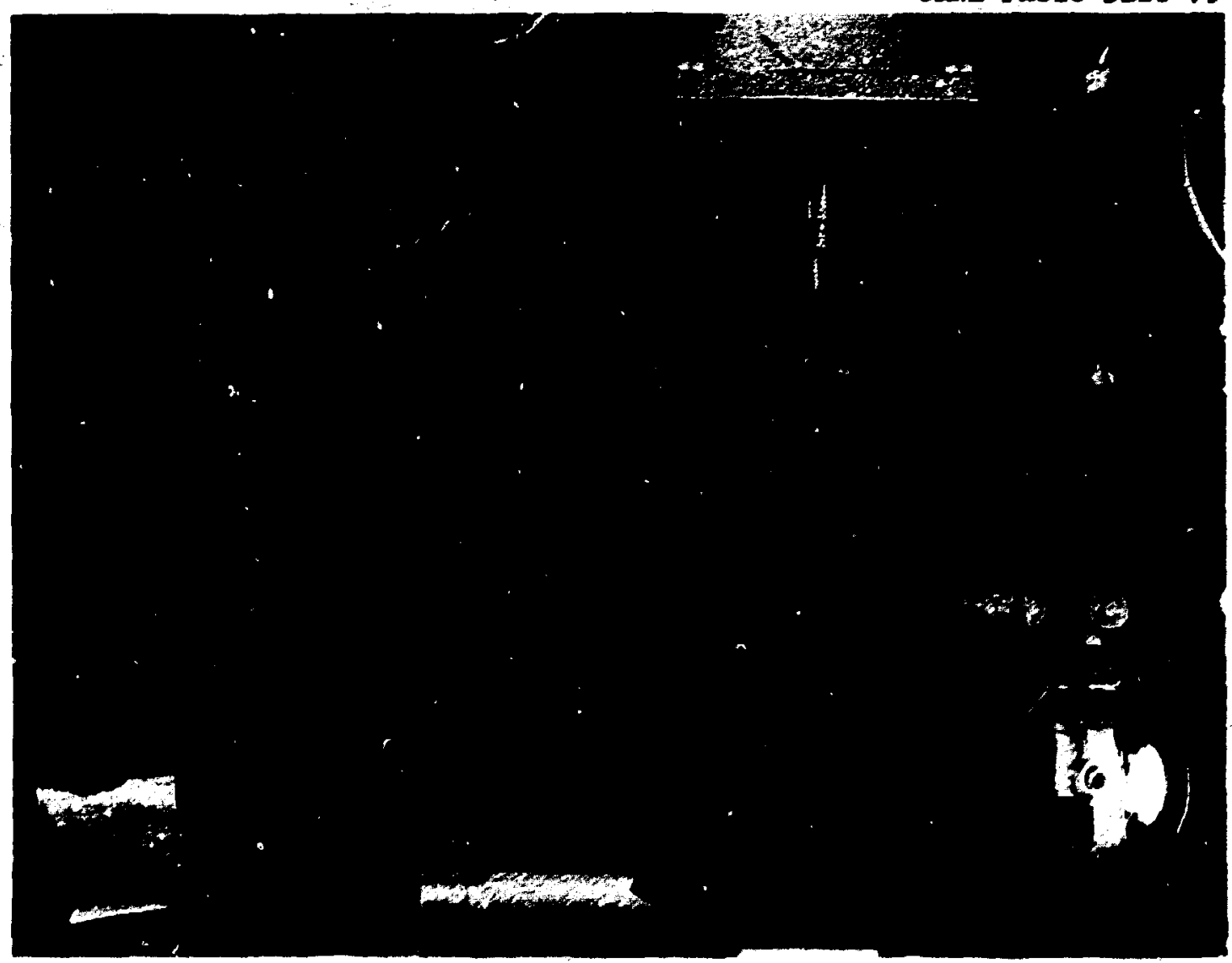

Fig. 7. Inside view of monochromator showing small vibrating mirror. 
The multipass "white" cell consists of a 9.5-cm-diam aluanue tube \$.5 long with 0.5- focal length mirrors in each end. The tirrors are coated for optimm reflectance in the UV region. The light bean can be adjusted for multiple reflections through the cell providing a long pathlength through the air sample. The instrument is usually normally operated with a cotal pathlength of $4 \mathrm{~m}$. The air sauple can be either continuousiy flored through the cell using a small punf or a volume of air can be trapped within the cell. The call volune is approxinately 3.51 .

Light detection is accoplished using a high-gain FrT with a quartz windov optinized for Uv response. For analysis of liquid samples, the multipass cell can be rewoved and the PrI holder rotated into the light beal directly behind the liquid cell holder.

\section{Electronics}

Figure 8 is an interior view of DUVAS showing the electronics, power supplies, stepping motor, monochromator, and lamp. Other than power supplies, all of the electronics are on a single printed circuit (PC) board (top of Fig. 8).

A block diagram of the DLVAS electronics is shown in Fig. 9. The second PC board is a commercially available (Pacific Photometric Instruments, Model 7151) voltage-programmable high-voltage (HV) power supply for the photomultiplier tube. A control voltage input of 0 to $5 \mathrm{~V}$ gives a 0 to $1200 \mathrm{~V}$ output. The programmable feature allows an automaticgain-control (ACC) signal to the HV board to control the gain of the PMT by varying the applied voltage. The second-derivative signal is not affected if the time constant of the ACC is slow relative to the $400-\mathrm{Hz}$ modulation frequency because slowly varying the gain is equivalent to slowly changing the light intensfty; the second-derivative signal is insensitive to light intensity changes. The AGC feature acts as an automatic iris to ensure that dc signals from the PMT are neither too small nor too large, thus ensuring that the signals fall within the optimum range of the signal processing electronics. 


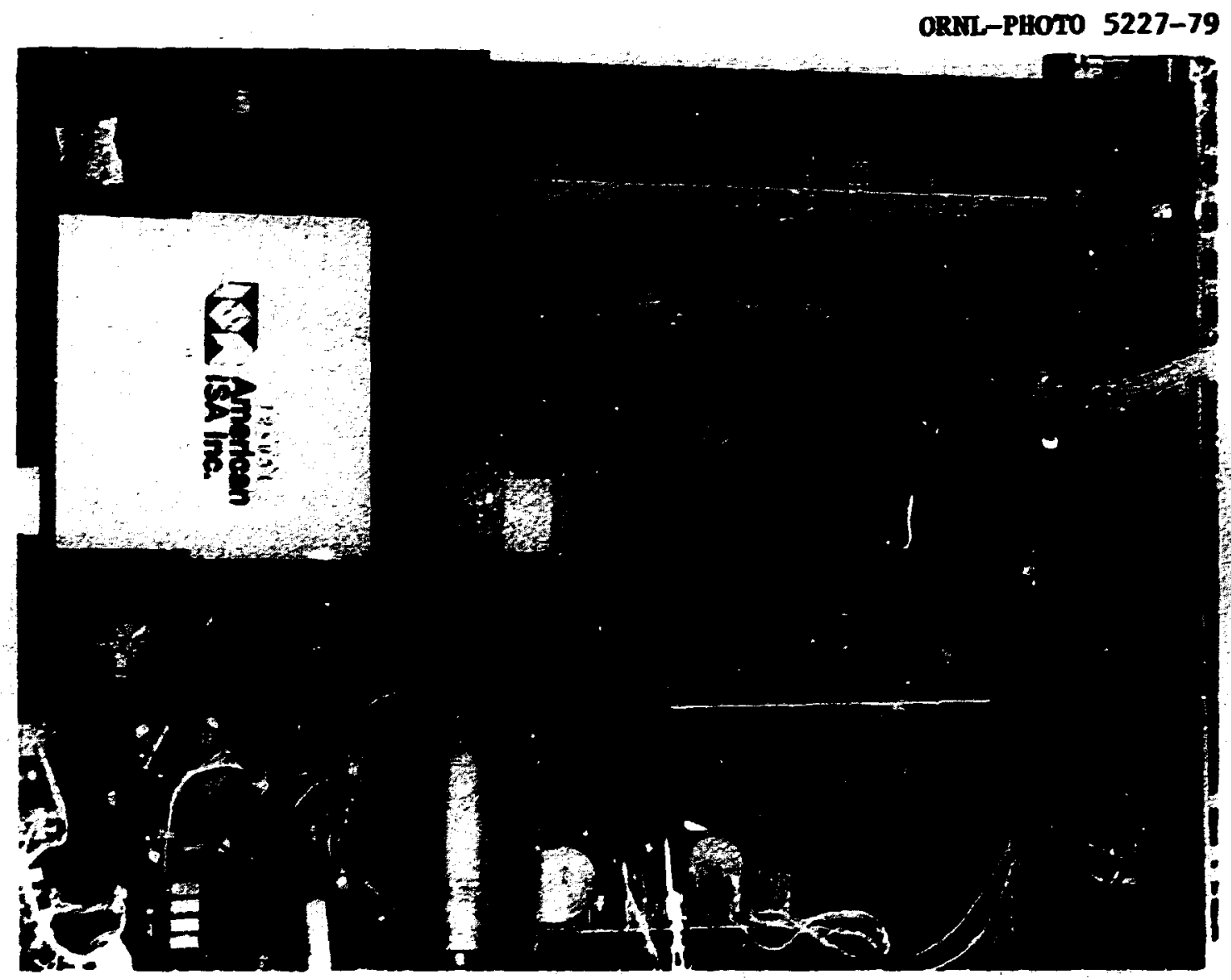

Fig. 8. Inside view of DUVAS showing 1ight source, wonochromator, stepping motor, electronics, and power supplies.

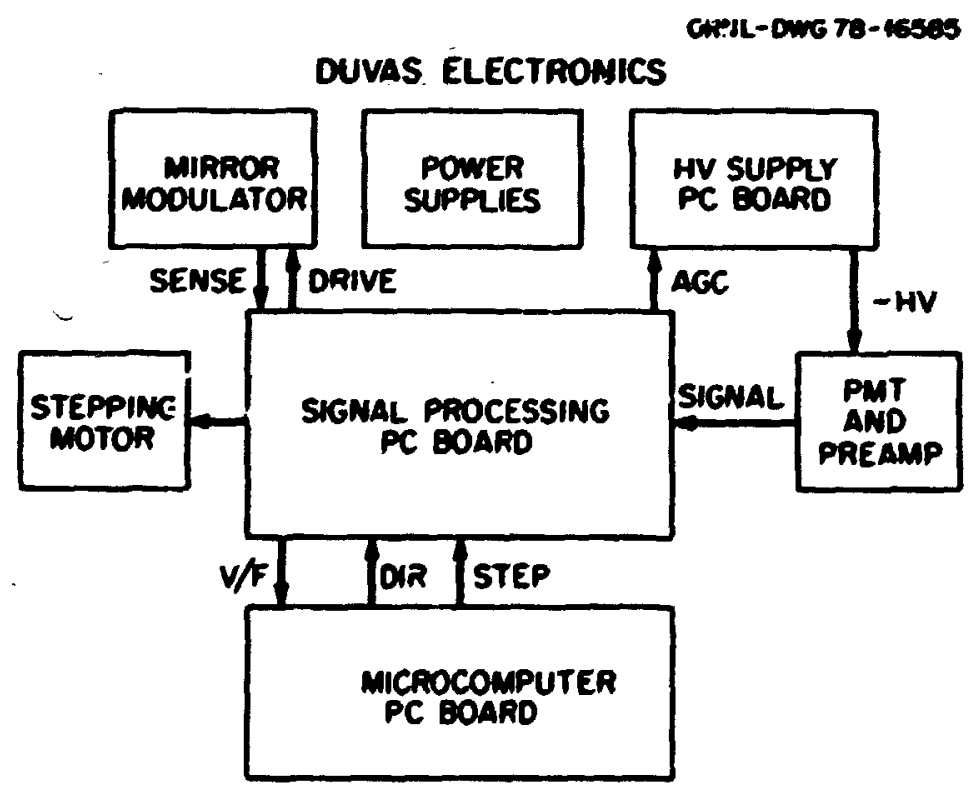

Pig. 9. Block diagram of vUVAS electronics. 
The signal processing and control circuits are shown in the block diagram of Fig. 10. The AGC circuit can be adjusted for the desired dc signal from the PMT. This AGC circuit then acts as a serve control to adjust the PIT voltage to the desired output. Also, or this PC board is the mixror-driving and sensing circuit. 25 Th:s circuit oscillates the mirxor and provides a 400-Hz reference signal to a frequency-doubling circuit, which gives an $800-\mathrm{Hz}$ reference signai for use in the sypchronous detector circuit. A stepping-motor control circuit takes a directios signal and step pulse from the microcouputse and provides the proper sequence of pulses to the bidirecicional four-plyase stcpping motor. When used with a 2:1 gear reduction, this motor gives a stepping resolutic: of $0.25 \mathrm{~nm} / \mathrm{step}$.

The signal frow the PMT, which has an $800-\mathrm{Hz}$ ac component containing the second-derivative information, is input to a logarithmic amolifier circuit. Following the $\log$ cirzult is a bandpass filter/amplifier with a central fre: sency of $800 \mathrm{~Hz}$. This circuit filters out both high and iow frequencies, including 120-Hz noise from line voltage and some of the 400-Hz signal due to the first-derivative signal. A synchronous detector circuit then selects only signals having an $800-\mathrm{Hz}$ frequency

ORNL-DWG 78-16586

\section{SIGNAL PROCESSING CIRCUITS}

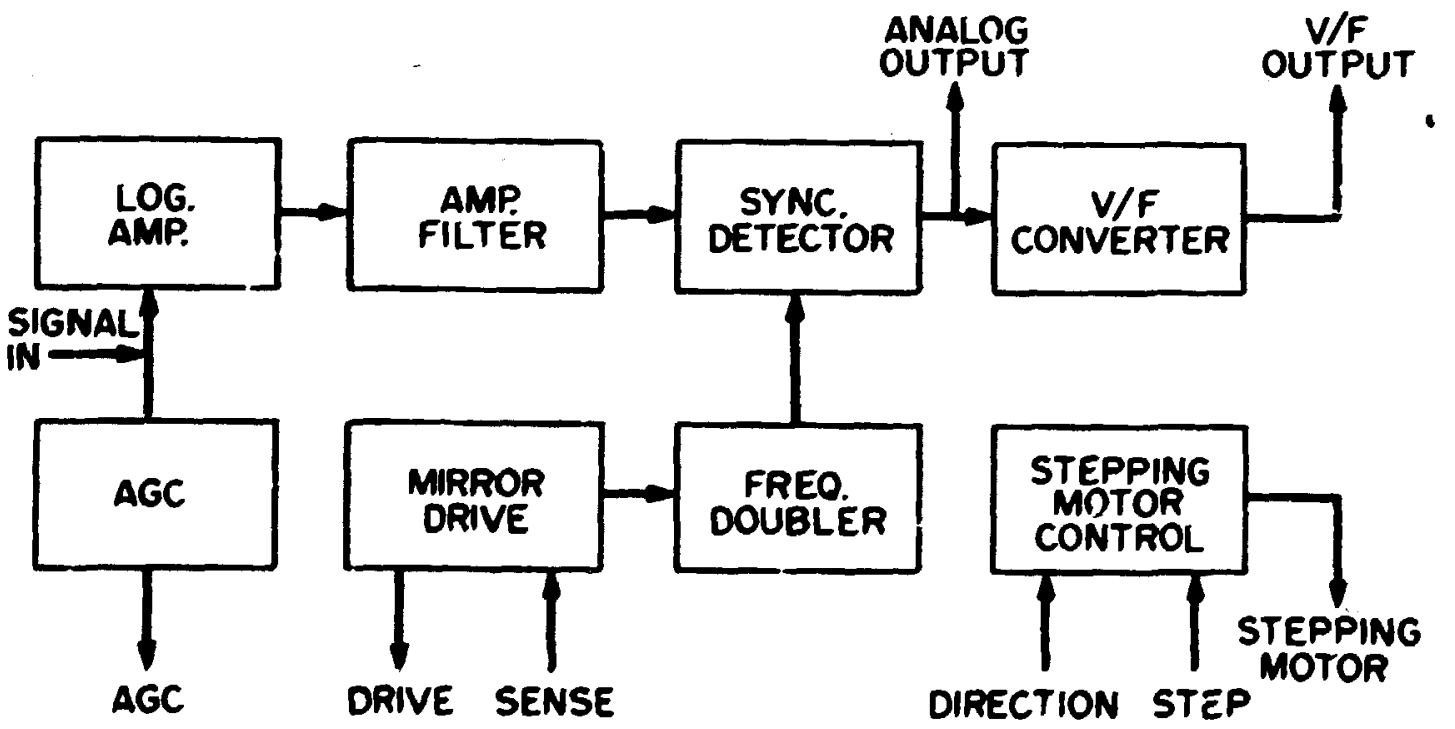

71g. 10. Block diagram of DUVAS signal processing, and control circuits. 
and, with a subsequent filter/amplifier circuit, converts this ac signel into a de signal proportional to the secord derivative or the absorption curve of the measuze zompound at the meastred wavelength. Tnis analog signal is available at the rear panel of the instrument for use with a chart $r$-corder. The final cizcuit on :.te vard is a voltage-to-frequency (V/F) converter; this provides a frer:encv signal pioportional to the second-der ivative signal for the microcompuier to recoif as Afgital data.

\section{Microrompiter}

DUVAS is cortrolled by a single-board computer (SBC) that attaches to the top of ine instrument box (Fig. 11). Commands are entered via a small keypad with data and status inf smation available to the user on a six digit LED display. The SBC is 16502 based microprocessor with

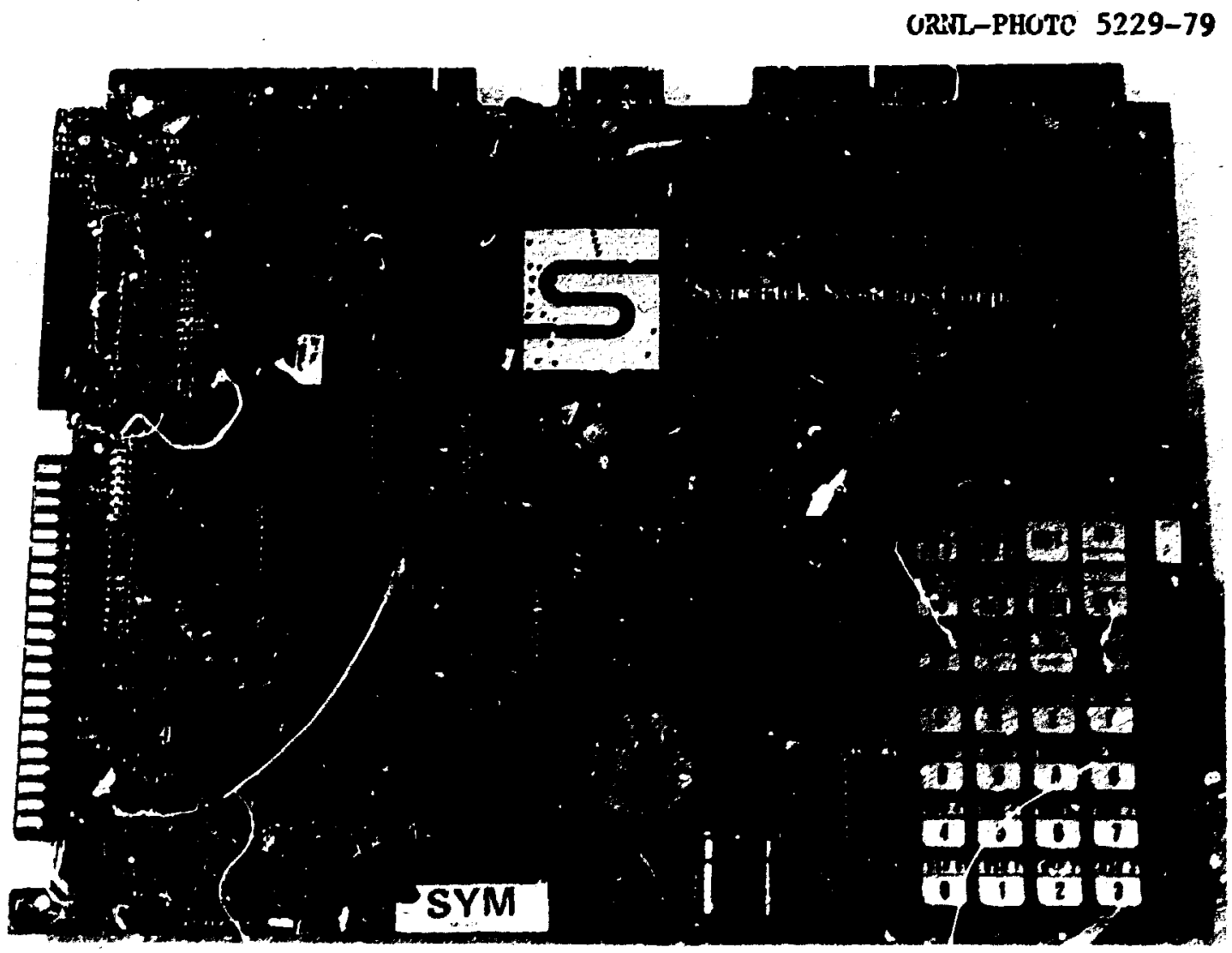

F1g. 1j, Phot.ograph of single-board micriscomputer tha'c controls DUVAS. 
2 kilobytes read-only-memory (ROM) monitor and 4 kilobytes of erasableprogramiable read-only-memory (EPROM) containing custom sof tware for DUVAS c perations. A detailed computer frogram listing is given in Apperdix B. Also included is $4 \mathrm{ki}$ ?obytes of randrum-access-memory (RAM) for storing spectra and temporary machine-language programs.

The microcomputer controls the vavelength positioning and scanning by prcriding a direction signal and a step pulse to the stepping motor control circuit. A memory register is mintained with the current location of tr a monochromator wavelength. The monochromator scan speed is sélectable.

A train of pulses proportional to the second-derivative signal is input to the microcomputer. A counter on tine SBC integrates the pulses for the period of time the monochromator is at a specific wavelength with the integration time being dependent on scan speed and resolution. The integrated signal is stored in the access spectrum buffer at the location corresponding to the current wavelength. The spectrum storage capacity is 256 data points, which corresponds to a wavelength range of $64 \mathrm{~nm}$ at a resolution cf $0.25 \mathrm{~nm} /$ data point and $128 \mathrm{~nm}$ at a resci tticn of $0.5 \mathrm{~nm} /$ data point.

The stored spectrum can be saved on an audio cassette recorder or transferred to another computer. DUVAS has a parallel input/output (I/O) port for high speed transfers and a $2 \mathrm{C}$-nm current loop for serial communication with a telesype or several other communication devices. Commands can be input to DUVAS via these external interfaces thus allowing remote control of the instrument by an external computer.

The DUVAS has been operated with : Digital Equipment Corporation (DEC) DECLAB 11/03 minicomputer and a C.omm,dore PET 2001 nifrocomputer. Figure 12 shows a spectrum displayed on the 11/03 system which is interfaced to an early version of DUVAS. For laborator; use the PDP 11/03 provides considerable flexibility, with dual floppy dics for mass data storage and program storage plus a video display for plotting spectra and displaying analyses. For field use the PET 2001 is an inexpensive microcomputer. It provides a 9-in. video display, a communfcation keyboard, a magnetic-tape cassette data recorder, and a microcomputer programmable in RASIC for data analysis (Fig, 13). 


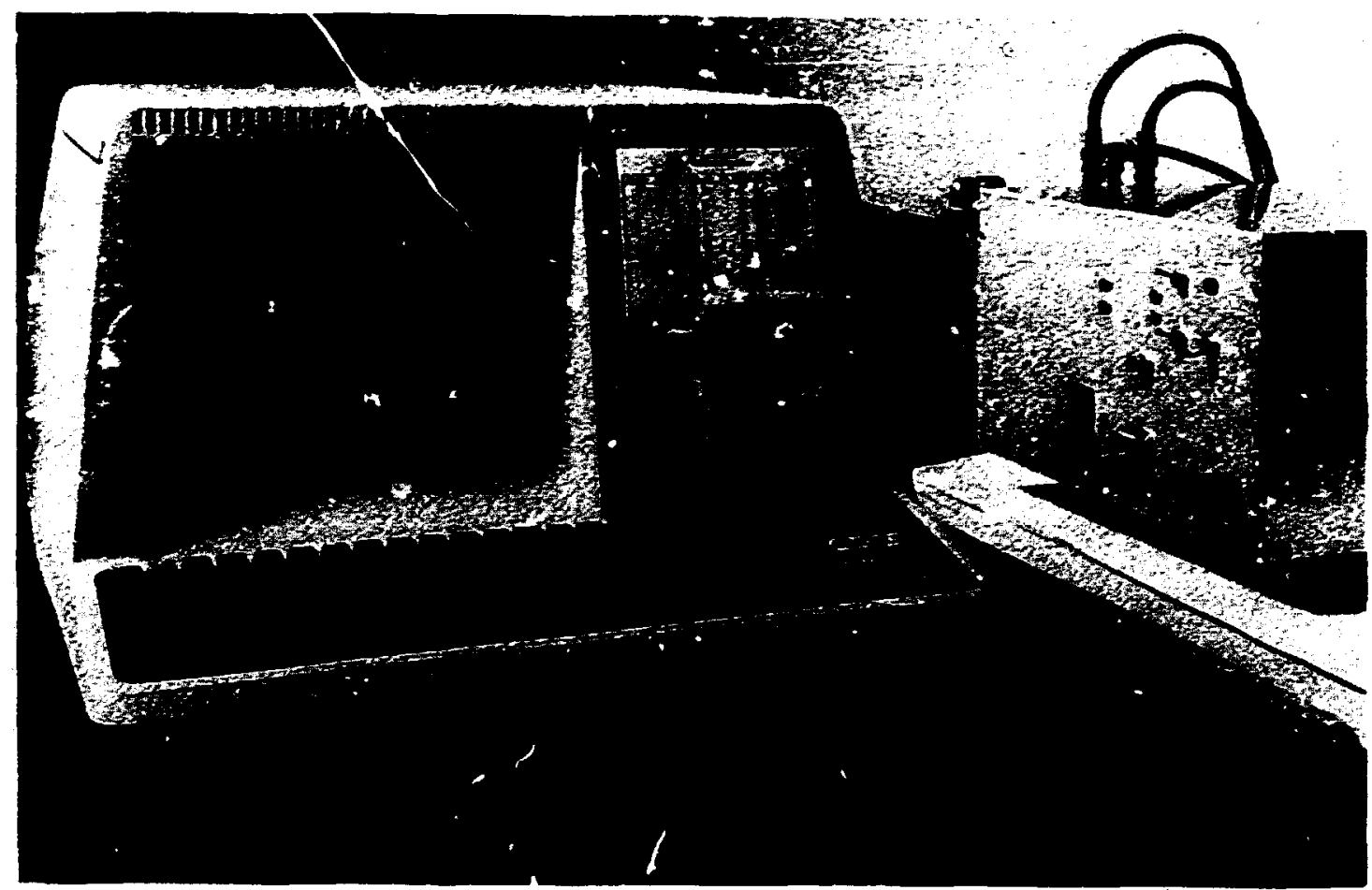

Fig. 12. DUVAS spectrum displayed on the DECLAB 11/03 system which is interfaced to an early vers on of DUVAS.

ORNL-PHOTO $4503-78$

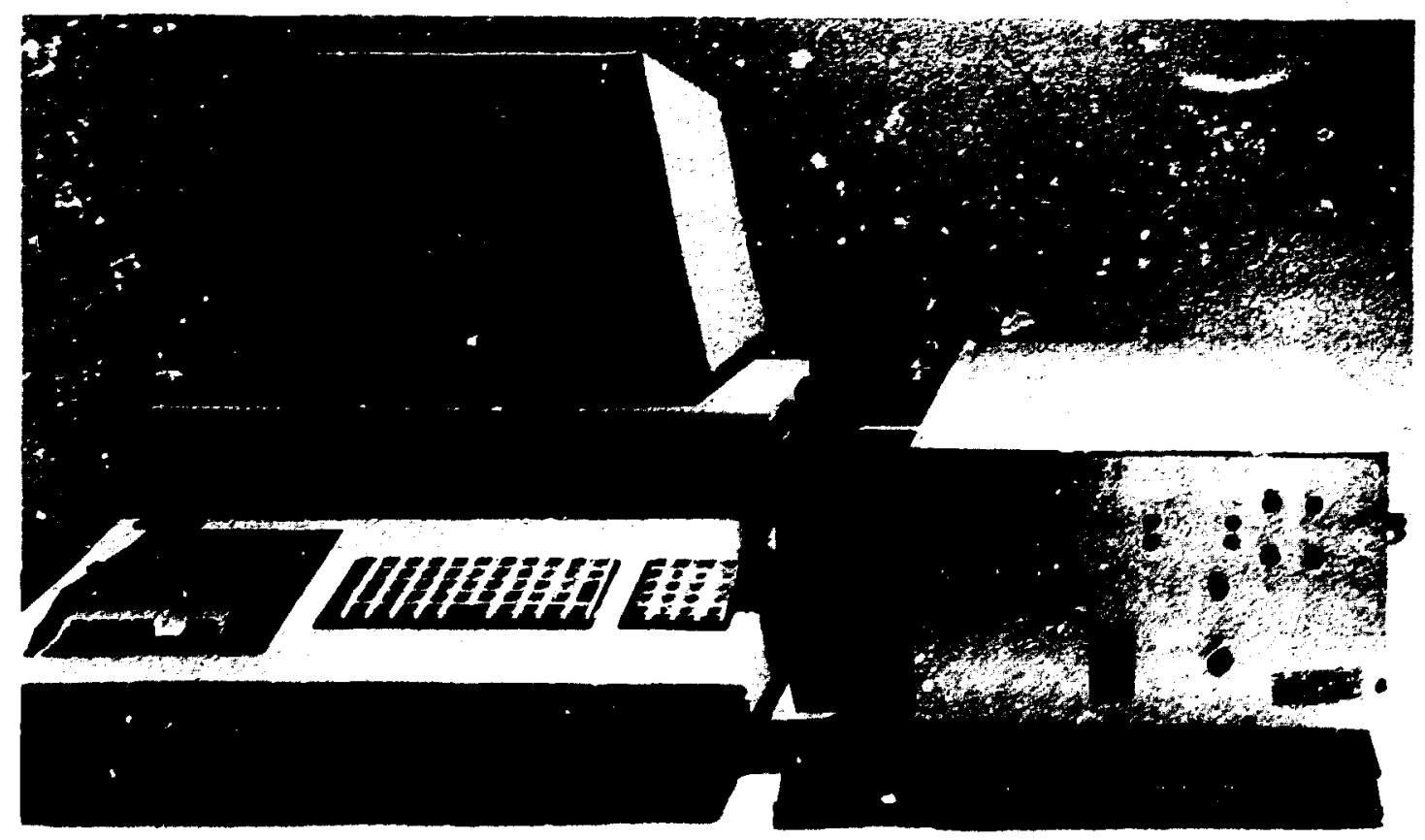

Fig. 13. DUVAS with liquid sampling compartment attached and interfaced with the PET 2001. 
Table 1 is a list of some of the comands available to the user via the SBC keypad. Some of the comands require a list of parameters prior to execution. These paraneters are (1) beginning vavelength of the scan, (2) length of the scan, (3) resolution of data storage (nm/data point), and (4) scanning speed ( $\mathrm{nm} / \mathrm{sec})$. The number of stored data points is the length divided by the resolution; the total scan time required is the length divided by the speed. An "access" command stores

Table 1. DUVAS comands to microcomputer

\begin{tabular}{|c|c|c|c|}
\hline Cormand & $\begin{array}{l}\text { Paraneters } a \\
\quad(Y / N)\end{array}$ & Function & Comment \\
\hline 3 & $\mathbf{Y}$ & Parameters & $\begin{array}{l}\text { Allows user to inspect or change } \\
\text { current parameters }\end{array}$ \\
\hline 4 & $\mathbf{N}$ & Auto & $\begin{array}{l}\text { Calibrates instrument wavelength using } \\
\text { a standard sample }\end{array}$ \\
\hline 5 & $\mathbf{N}$ & Smooth & $\begin{array}{l}\text { Provides a 5-point smooth of the } \\
\text { stored data }\end{array}$ \\
\hline 9 & $\mathbf{N}$ & Scope & $\begin{array}{l}\text { Provides an analog signal of stored } \\
\text { data for oscilliscope or recorder }\end{array}$ \\
\hline $\mathbf{A}$ & $\mathbf{Y}$ & Access & $\begin{array}{l}\text { kecords a spectrum using specified } \\
\text { parameters }\end{array}$ \\
\hline B & $\mathbf{Y}$ & Time & $\begin{array}{l}\text { Same as access but monochromator not } \\
\text { scanned }\end{array}$ \\
\hline C & $\mathbf{N}$ & Copy & $\begin{array}{l}\text { Copies access spectrum into background } \\
\text { spectrum }\end{array}$ \\
\hline D & $\mathbf{Y}$ & Dwell & $\begin{array}{l}\text { Continuously displays voltage at start } \\
\text { wavelength }\end{array}$ \\
\hline $\mathbf{E}$ & $\mathbf{N}$ & Exchange & $\begin{array}{l}\text { Exchanges access spectrum with back- } \\
\text { ground spectrum }\end{array}$ \\
\hline$F$ & $\mathbf{N}$ & Fix & $\begin{array}{l}\text { Allows user to assign wavelength of } \\
\text { current monochromator setting to } \\
\text { computer }\end{array}$ \\
\hline - & $\mathbf{N}$ & Subtract & $\begin{array}{l}\text { Subtracts the backgroind spectrum from } \\
\text { the access spectrum }\end{array}$ \\
\hline SAV 2 & & & Storea spectrum on cassette \\
\hline LD 2 & & & Reads spectrum from cassette \\
\hline
\end{tabular}


a spectrun taken with the specified paramet $s$ in the access buffer. A "tive" comand operates like the "access" comand except that the monochronator is not scanned. This provides a tine spectrun showing the variation in the second-derivative response at the starting wavelength with time, where the total time is iength divided by speed and the time per data point is resolution divided by speed. The "dwell" comand is similar to the "time" comand except the data are not stored in the spectrum buffer but continuously output on the LED display. The "duell" mode is exit. 1 by pressing a key on the SBC keypad. The "paraweters" command allows the user to inspect or change current scaming paraneters.

In addition to the access spectrum buffer, there is a background spectrum buffer in the microcomputer mewory. The "copy" comand transfers the spectrum currently in the access buffer to the background buffer. The "exchange" comand swaps spectra between the two buffers. A "subtract" command subtracts the background buffer from the access buffer, providing the parameters of the two spectra are the same. The resulted spectrum is stored in the access buffer. Another data manipulation command is the "smooth" comand which performs a 5-point smoothing of the data in the access buffer.

When DiVAS is powered-up, the microcomputer does not know at what wavelength the monochromator is positioned. Two commands are available to calibrate the wavelength. One comand, "fix" simply assigns the current position to the wavelength that the user provides as input from looking at the monochromator dial. The other, more acculate method, Is the "auto" comnand. The microcomputer scans over a preassigned wavelength region and looks for a peak from a standard calibration sample. The maximum value of this peak is assigned the wavelength value of the 8 andard compound.

Data stored in the access buffer can be output a variety of ways. The "scope" command scales the data in the access buffer and outpits an analog signal from a digital-to-analog conver : (DAC) that can be used with an oscilloscope to provide a visual display of the complete spectrum. Also output are the starting wavelength, the ending wavelength, the amplitude of the data, and the position and value of cursor which can be moved to any data point. These alphanumeric characters are multi- 
plexed with the spectral data to provide an informative and convenient display for the user. Another option of the scope command is to output the analog signal at a slow rate suitable for recording on an $X-Y$ plotter or a chart recorder. The alphanumeric information is not output in this mode.

Spectra can also be saved and retrieved using an audio cassette recorder with the "save" and "load" commands. This is a convenient method of keeping spectra for later plotting and data analysis. 


\section{EVALUATION}

The prototype DUVAS has been tested and evaluated during the past six months in botk: laboratory and field applications. 18 Additional evaluations are continuing to accumulate a data base of instrunent performance under varying conditions. Table 2 lists some of the vapors and gases that can be measured using DUVAS along with their threshold. limit values (TLVs) where applfcable and an approximate detection linit, based on a $S / N$ of 3 , when no interferences are present. Unless otherwise noted, the pathlength of the measurement is $4 \mathrm{~m}$. Appendix $A$ is a library if second-derivative spectra.

Table 2. Approximate detection 1inits for soue aronatic vapors

\begin{tabular}{lrc}
\hline \multicolumn{1}{c}{ Compound } & $\operatorname{TLV}^{a}$ (ppm) & $\begin{array}{c}\text { Approximate detection } \\
\text { limit (ppm) }\end{array}$ \\
\hline Benzent & 10 & $0.06^{b}$ \\
Cresol & 5 & $0.06^{b}$ \\
Phenol & 5 & $0.06^{b}$ \\
Naphthalene & 10 & $0.001^{b}$ \\
Toluene & 200 & $0.1^{b}$ \\
Methylnaphthalene & & $0.001^{b}$ \\
Indane & & $0.09^{b}$ \\
Benzaldehyde & & $0.05^{b}$ \\
Formaldehyde & 3 & $0.5^{b}$ \\
Ammonia & 50 & $0.003^{c}$ \\
Sulfur dioxide & 5 & $0.003^{c}$ \\
Nitric oxide & 25 & $0.02^{c}$ \\
Nhtrogen dioxide & 5 & $0.04^{c}$ \\
Ozune & 0.1 & $0.05^{c}$ \\
\hline
\end{tabular}

$a_{\text {Threshold limit value. }}$

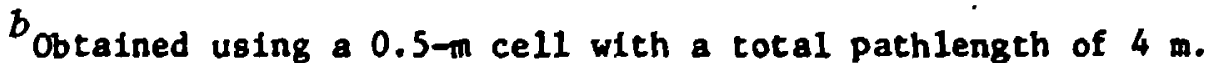

obtained using a 1-m cell with a total pathlength of $12 \mathrm{~m}$. 
A typical calibration curve is shown in Fig. 14. The dynanically generated concentration was produced by vaporizing a know solution of naphthalene in cyclohexane into an air streas. This is accomplished by injecting the solution, using a syringe pup, into the strean of hot air. This procedure is used to callitzate liquid and solid compounds. Gases such as $\mathrm{SO}_{2}, \mathrm{NH}_{3}$, and $\mathrm{HO}_{\mathbf{x}}$ are diluted from comercial compressed gas cylinders (usually 50 ppe in $\mathrm{H}_{2}$ ). All flow measurements are made using wass flow weters calibrated with a wet test meter. Cross verification of calibration has beea performed using a static air saple produrs by injecting a small aprunt of sample directly into the DJVAS mulizpass sampling cell using a microsyringe with the inlet and exit of the cell closed.

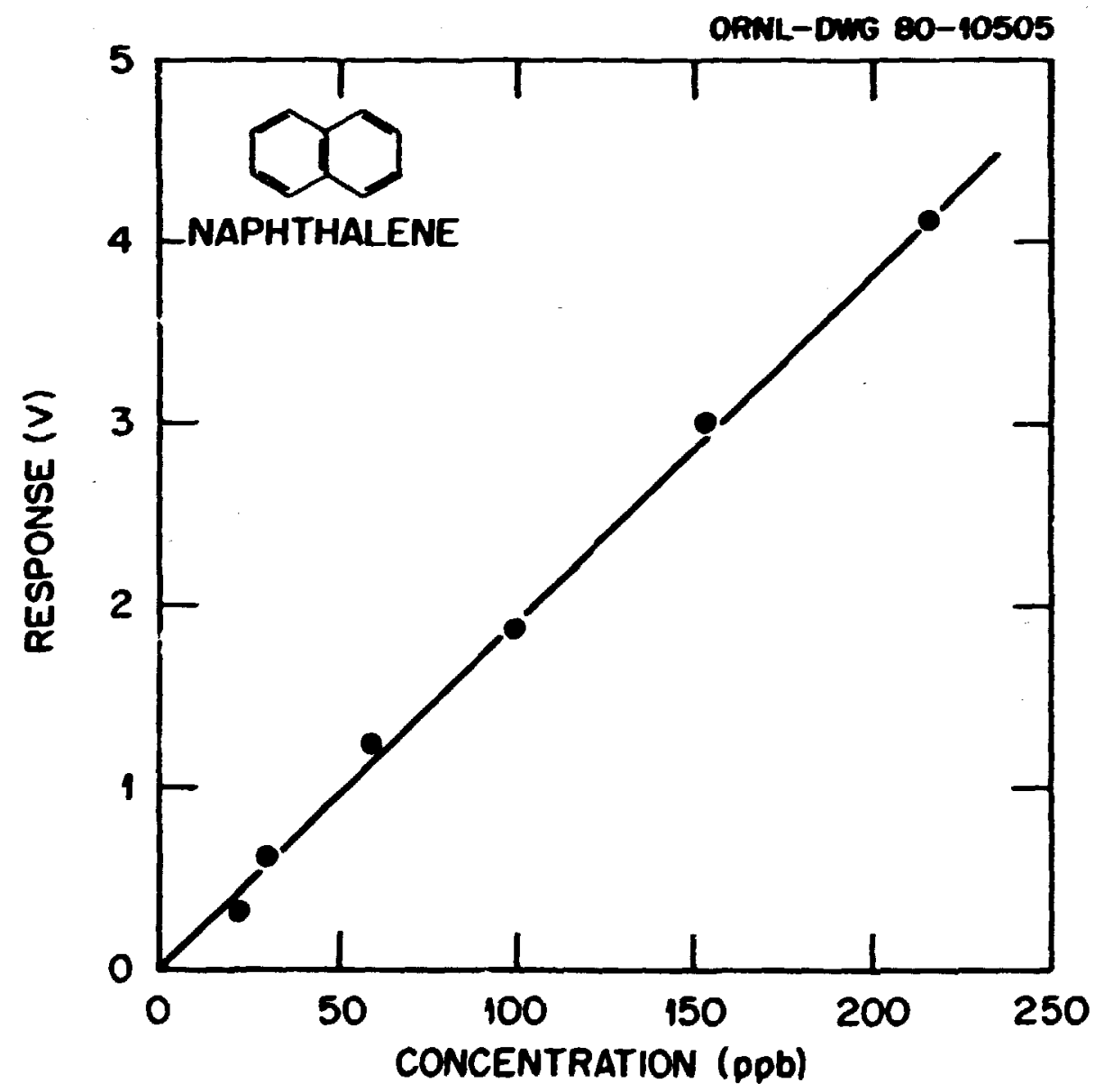

718. 14. A typlcal vapor calibration curve for DUVAS generated using a dynatic flow system. 
The systen response time is determined primarily by the sample ceil. volume and the flow rate of air through the cell. Equilibrium response is unaffected by flow rate. The response time (90z of value) to a step change in concentration due to the 0.5 m sampling cell volume $(3.5 \mathrm{~L})$ is approximately $25 \mathrm{~s}$ for a $10 \mathrm{~L} /$ min flow rate. By expressing time as a norwalized parameter $(t / \tau)$ where $\tau=$ cell volume divided by flow rate, the instrument response to a step increise in concentration can be shown independent of flow rate and cell volume. Figure 15 shows the normalized response of DUWAS as well as the expected response assuming either perfect wixing or plug flow in the cell. As expected, the instrument response lies between these two idealized cases. The time required to

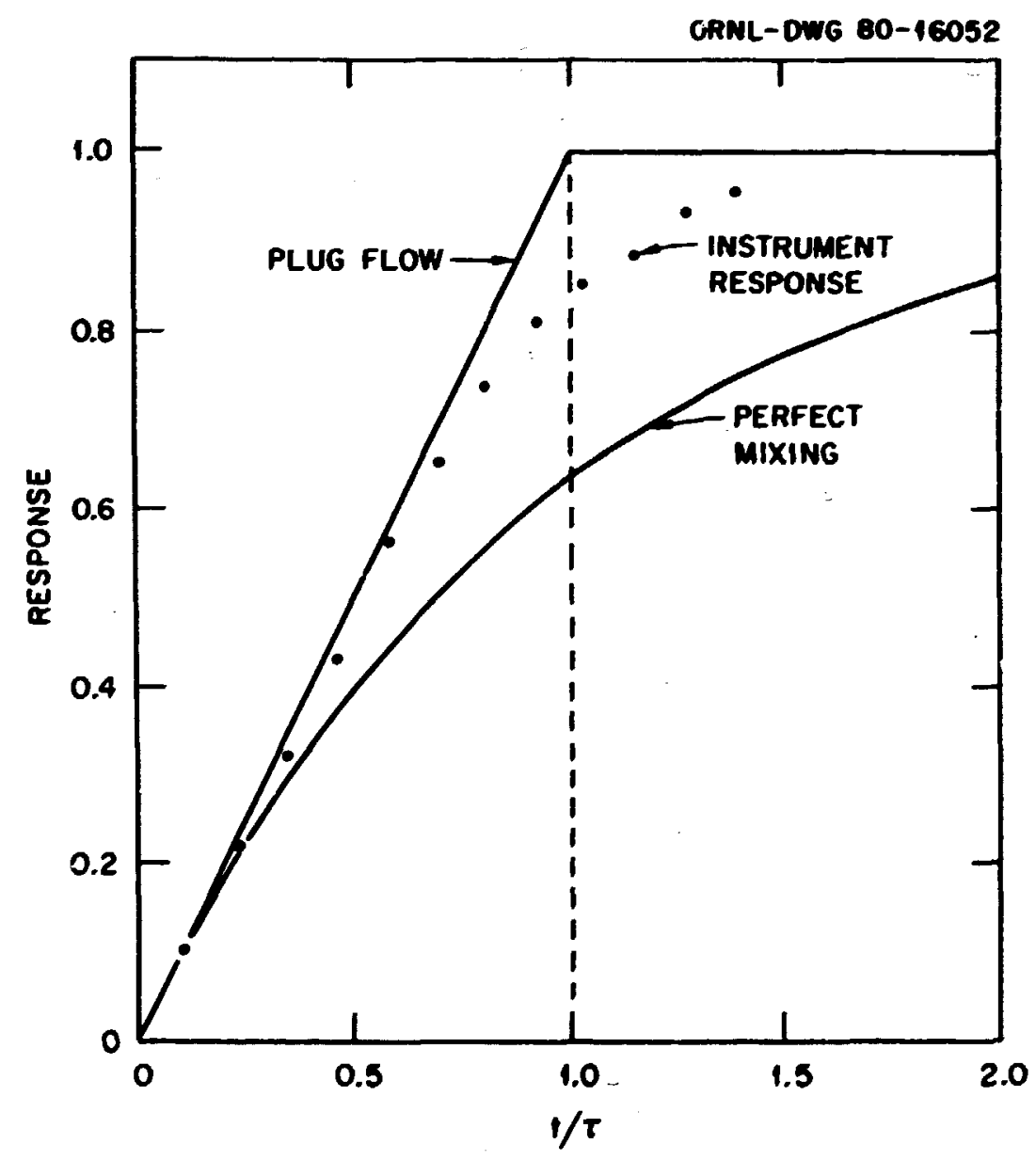

F18. 15. DUVAS response to a step increase in vapor concentration as a function of $t / \tau$ where $\tau$ equals cell volume divided by flow rate. (Wote: $t$ must be in same un1ts as $\tau_{0}$ ) 
reach $90 z$ of equilibrium response is approximately $1.15 \tau$. Figure 16 shows the response time for a cell volume of $7 \mathrm{~L}$ and a flow rate of $5 \mathrm{~L} / \mathrm{min}$ ( $\mathrm{f}$.e., $\tau=1.4 \mathrm{~min}$ ). DUVAS was alternately measuring naphthalene and methylnaphthalene vapors above a Synthoil sample. The afr flow was shunted around the sample at $t=3 \mathrm{~min}$ and returned to the original flow path at $t=6$ min.

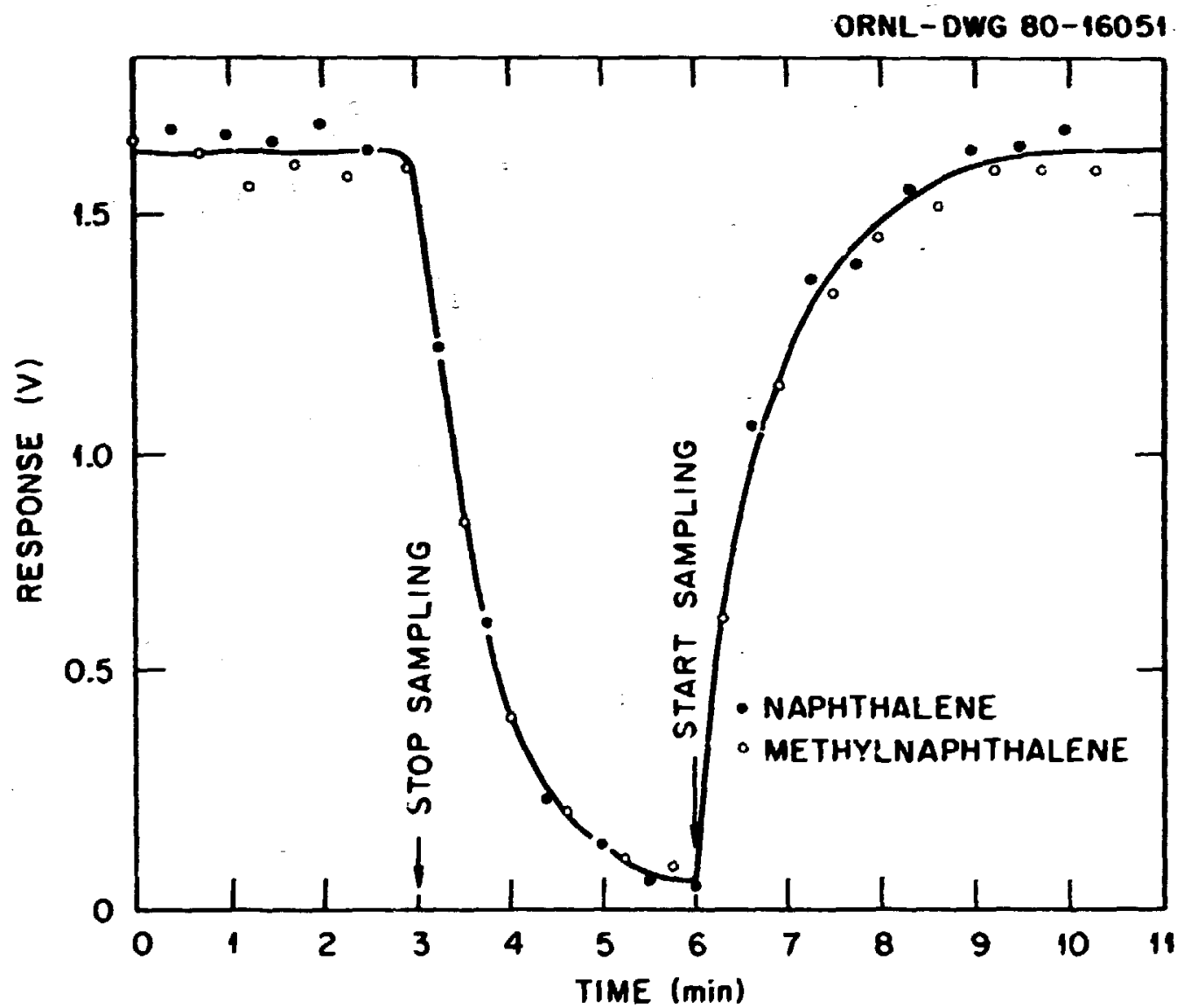

F18. 16. Variation of naphthalene and methylnaphthalene vapor from a synthoil sample 1llustrating the DUVAS response to a step decrease and increase in concentration.

Care must be exercised in operating the air sampling cell in the static mode with low vapor pressure compounds such as naphthalene since a background response can build up requiring excensive flushing and heating of the cell to reduce the level of background response. This is much less of a problem when afr 18 continuously flowed through the cell and requires attention only when a very low level measurement follows a relatively high level measurement of a low vapor pressure compound (or a particularly absorptive compound such se $\mathrm{NH}_{3}$ ). 
The precision of the DUVAS response is a function of signal strength and measurement speed. For samples yielding a response not limited by nc ise, the reproducibility is 27 or less for short-term measurewents. 18 For example, 18 measurements of a $0.5 \mathrm{ppm}$ No sample yielded $\bar{x}=0.500 \pm 0.010 \mathrm{ppm}$ for a measurement ime of $9 \mathrm{~s}$ per measurement. For a longer measurement period of $1 \mathrm{~min}, 60$ measurements of an unknown anthracene liquid sampie gave a result of $4.887 \pm 0.045 \mu \mathrm{g} / \mathrm{ml}$ (<12 RSD). Wavelength drift is not a problem with. the wonochromator being positioned by a stepping motor. Once the initial auto calibration function is exercised after each startup, the wavelength remins locked within one motor step $(<0.25 \mathrm{~nm})$. The long-terw dowward drift of lapp intensity due to aging does not pose a problen since the second-derivative response is independent of source intensity. Calibration curves have remained constant when rechecked up to six months later.

DUVAS is capable of operating in three modes: (I) continuous scanning, (2) monitoring a specific wavelength with time, and (3) sequential multiwavelength measurement. The continuous scanning mode uses the "access" command and associated spectrum parameters such as scanning speed and spectrum length. Figure 17 is a typical spectrum of an aromatic vapor taken using this mode of operation.

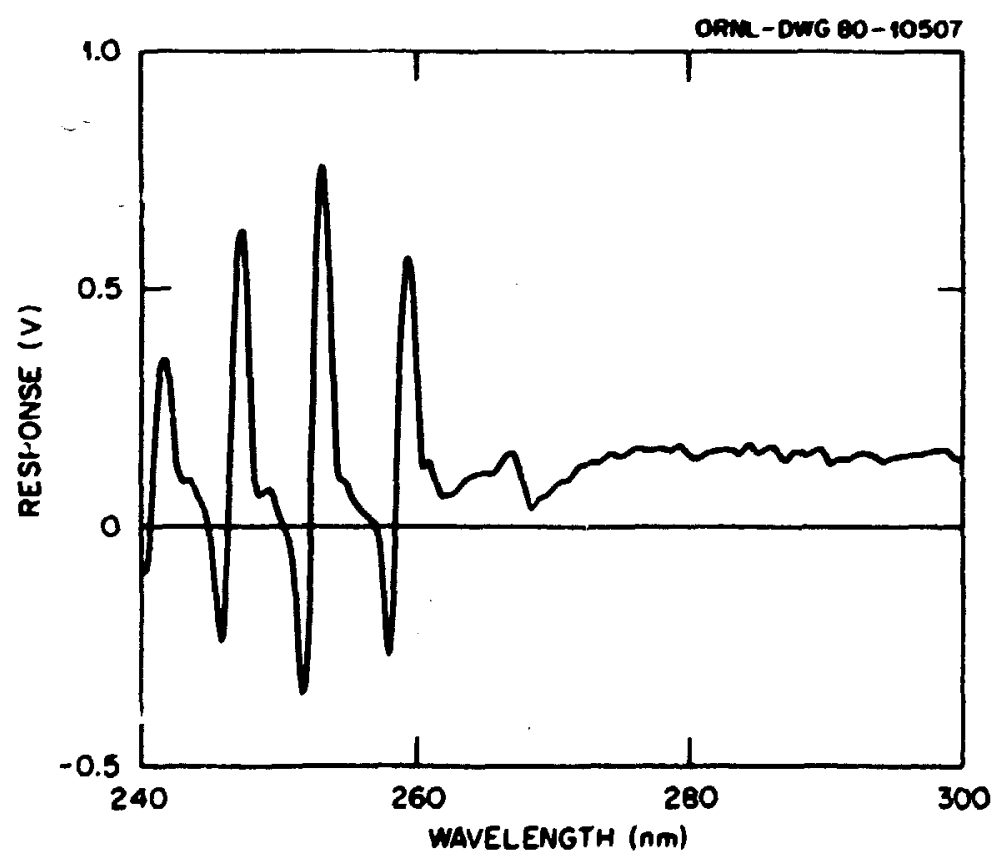

F18. 17. DUVAS spectrum of benzene vapor fllustrating a typical aromatic vapor spectrum. 
The second wode of operation is imlemented using either the "time" or "dvell" comands. Figure 18 is a cime spectrum of benzene vapor monitored at the 254-nn peak showing equilibration after iujection of a microsyringe of benzene fnto the closed sapling cell. This wde of operation is useful when a tire history of concentration is desired. By utilizing the DUVAS analog signal, a real-tine alarm can be iplenented when a predeternined level has been exceeded.

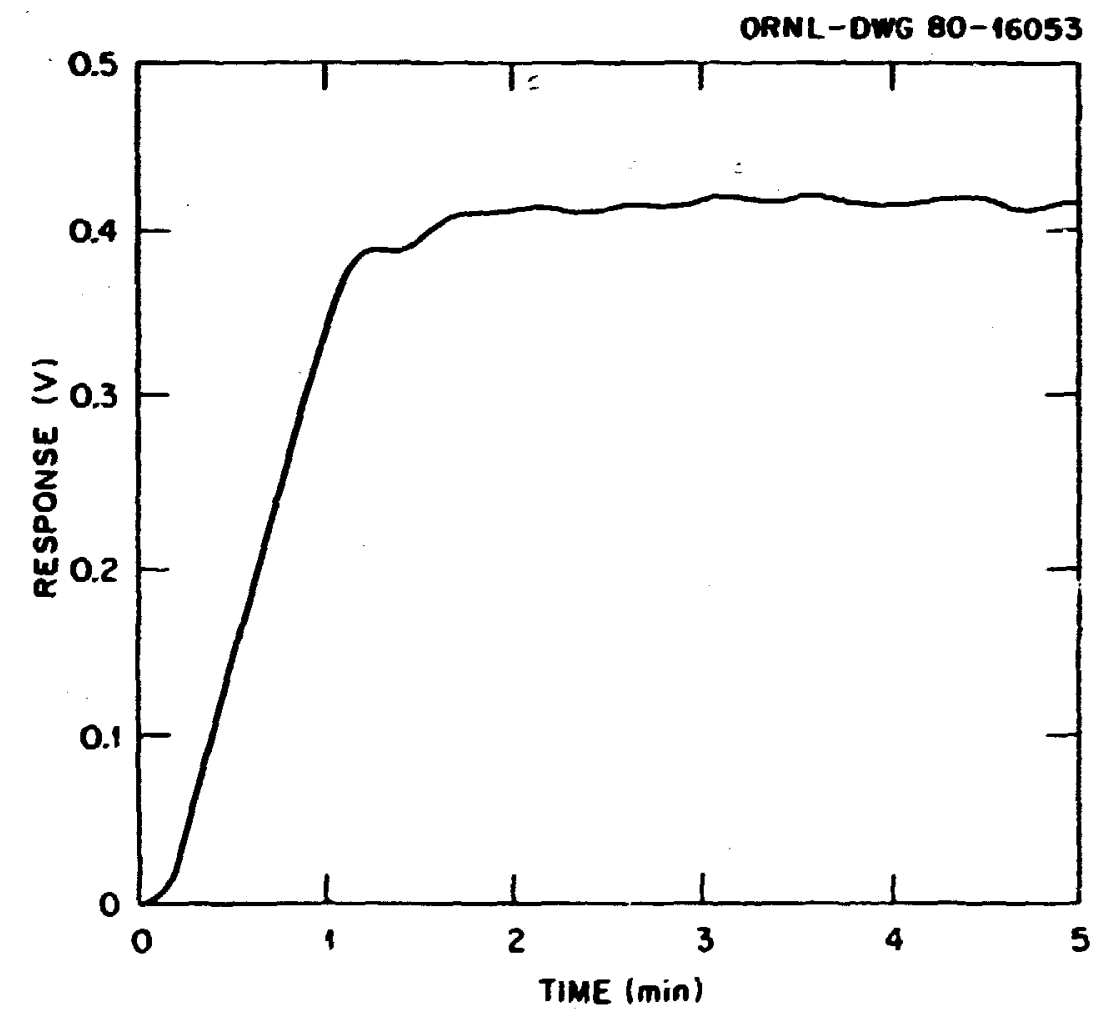

Fig. 18. Time spectrum of benzene vapor monitored at the 254-nm peak showing equilibration after injecticn of a microsyringe of benzene into the closed sampling cell.

The third mode of operation is performed in conjunction with an extemal computer. In this mode of operation, the DUVAS is instructed to dwell for a short measurement at the wavelength where the minimum voltage occurs for the measured compound followed by a dwell at the wavelength of the maximum voltage (see $\mathrm{Fig} .1$ ). The difference of the voltages is multiplied by a calibration constant and displayed on the host computer as a concentration in ppm. Using this mode of operation, DUVAS can rapidly measure several compounds and repeat the serles at a 
specified time interval. The above discussed exaple of 18 measureanents of a 0.5 ppa No sample to assess precision was obtatned using the PET 2001 and this mode of operation. Interference corrections can be wade using an interference atrix that is formed by measuring the response of the various compounds at all of the specified wavelengths.

Another wethod of interference correction uses the least-squares technique and a complete spectru in conjunclion with a library of sfectra. As an illustration of the selectivity of the derivative technique coupled with least-squares analysis, a mixture containing four PMA compounds in cyclohexane vas prepared. The sample noninally contained $25 \mathrm{ng} / \mathrm{ml}$ each of anthracene, phenanthrene, chrysene, and pyrene. Pure compounds were employed to generate "standard". spectra for use in the least-squares analysis. Spectra of both the pure compounds and the mixture were measured using a $1-\mathrm{cm}$ cuvette containing $\sim 2$ al of solution. Figure 19 shows the spectra obtained for each of the standard solutions. Notice the considerable variation in measured response per concentration for the different compounds, witi anthracene providing 220 times more intense response at the peak near $253 \mathrm{~nm}$ than does phenanthrene. Also, note the severe overlapping of absorption peaks between the different compounds, especially for anthracene and phenanthrene near $253 \mathrm{~nm}$, which would make graphical analysis very unreliable.

The measured spectrum and least-squares fit of the mixture are shown in Fig. 20. Table 3 lists the analytical results obtained from the least-squares analysis. Alchough the concentrition deterwined for the relatively less intense phenanthrene is only $76 z$ of its true value, the least-squares program tells the user that the standard deviation of the phenanthrene resule is greater than the others; in fact, the determined value 18 within 30 of the true value. The least-squares analysis of a complete spectrum with library standards is generally restricted to a laboratory-based computer with a fairly fast (relative to cassette tapes) mass storage device. Interference corrections made in the field will likeiy be confined to a selected number of wavelengths and compounds (10 or 1ess). 


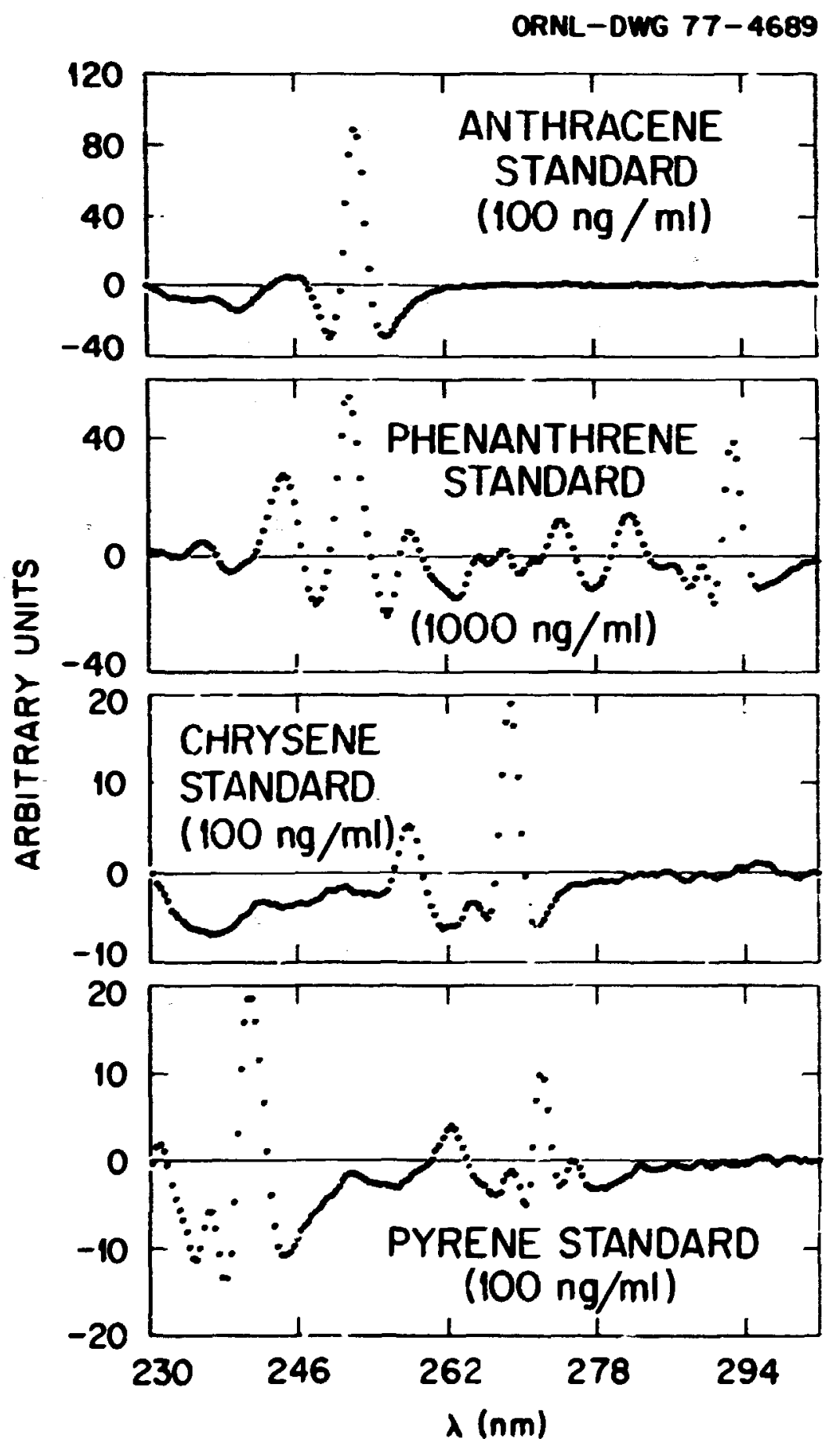

P1g. 19. Liquid calibration standards for four PNA compounds in cyclohexane used to fllustrate selectivity. 


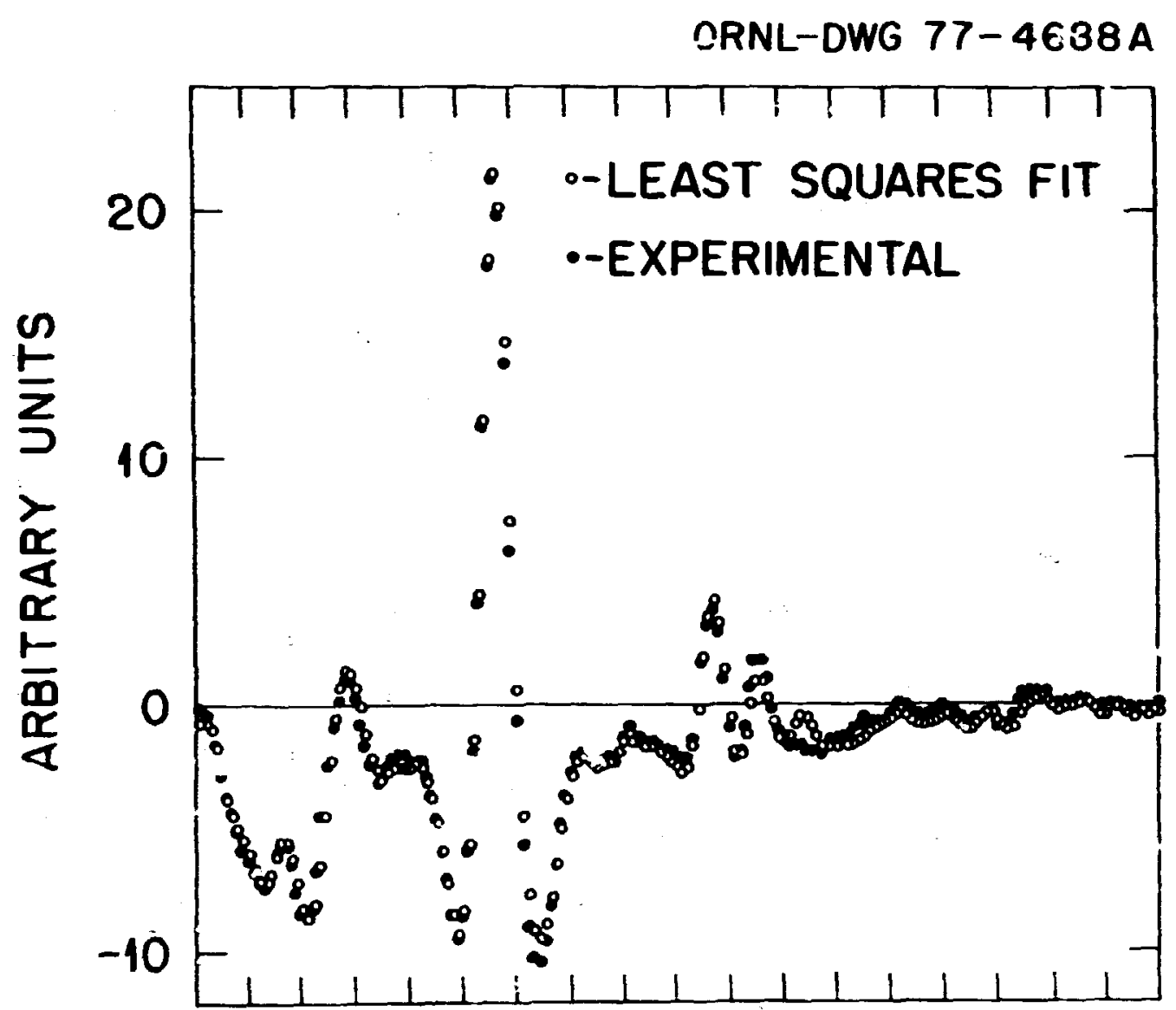

Fig. 20. Comr arison of least-squares spectral fit to experimental spectrum obtained with DUVAS.

Table 3. Least-squares analysis of a mixture of $f$.ur PNA compcinds in cyclohexane obtained using derivative spectrometry

\begin{tabular}{lcc}
\hline Compound & $\begin{array}{c}\text { Nominal } \\
\text { concentration } \\
(\mathrm{ng} / \mathrm{ml})\end{array}$ & $\begin{array}{c}\text { Least-squares } \\
\text { analysis } \\
\text { (ng/m1) }\end{array}$ \\
\hline Anthracene & 25 & $25.4 \pm 0.2$ \\
Chrysene & 25 & $25.0 \pm 0.7$ \\
Phenanthrene & 25 & $18.9 \pm 2.6$ \\
Pyrene & 25 & $28.2 \pm 0.6$ \\
\hline
\end{tabular}




\section{APPLICATIONS}

DUVAS should prove valuable in monitoring trace pollutants in a wide range of applications. Specific projects include monitoring wastewater streams of synfuel and other industrial plants, mexsuring several Environmental Protection Agency criteria pollutants at remote sł.tes, monitoring coal-fired power plant smoke wes, measuring indoor air pollution, and monitoring industrial hygiene for aromatic vapors. Additional, non-inalth and safety, projects wight include such applications as use in real-time process control instrumentation in synfuel plants for optimizing yields of various compounds by varying process operating parameters. A few sp'cific examples will be given in this section to illustrate the type of results that can be obtained using the inst rument.

Organic compounds such as phenol and cresols in wastewaters from synfuel and other industrial plants must be cleaneó prior to release to the entironment. DUVAS should prove fepsible as a continuous on-line wastewater monitor for these compounds. ${ }^{13}$ Figure 21 shows a calibration curve for phenol in water. The selectivity obtained with the secondderivative technique is illustrated using a mixture of phenol and $m_{\text {-cresol. }}$ The main second-derivative peaks for phenol and m-cresol are separated by slightly more than $1 \mathrm{~nm}$. When a least-squares spectral analysis computer program was applied to the spectrum, the analysis of the mixture yielded $20.2 \mathrm{\mu g} / \mathrm{mL}$ of phenol and $18.7 \mathrm{\mu g} / \mathrm{ml}$ of $\mathrm{m}$-cresol as compared to the expected values of $20.0 \mu \mathrm{g} / \mathrm{mL}$ of each compound. The analys is is espectally good considering the high degree of similarity between the two absorption spectra.

A particu'ar advantage of the second-derivative technique applied to environmental and industrial hygiene monitoring problems is the dramatically reduced effect that sample turbidity has on the spectrum. A turbid sample generally produces an absorption which varies slowly with wavelength so that taking the second derivative tends to remore from the spectrum the contribution dile to sample turbidity. A direct spectrum obtained for a turbid wastewater sample containing phenol 


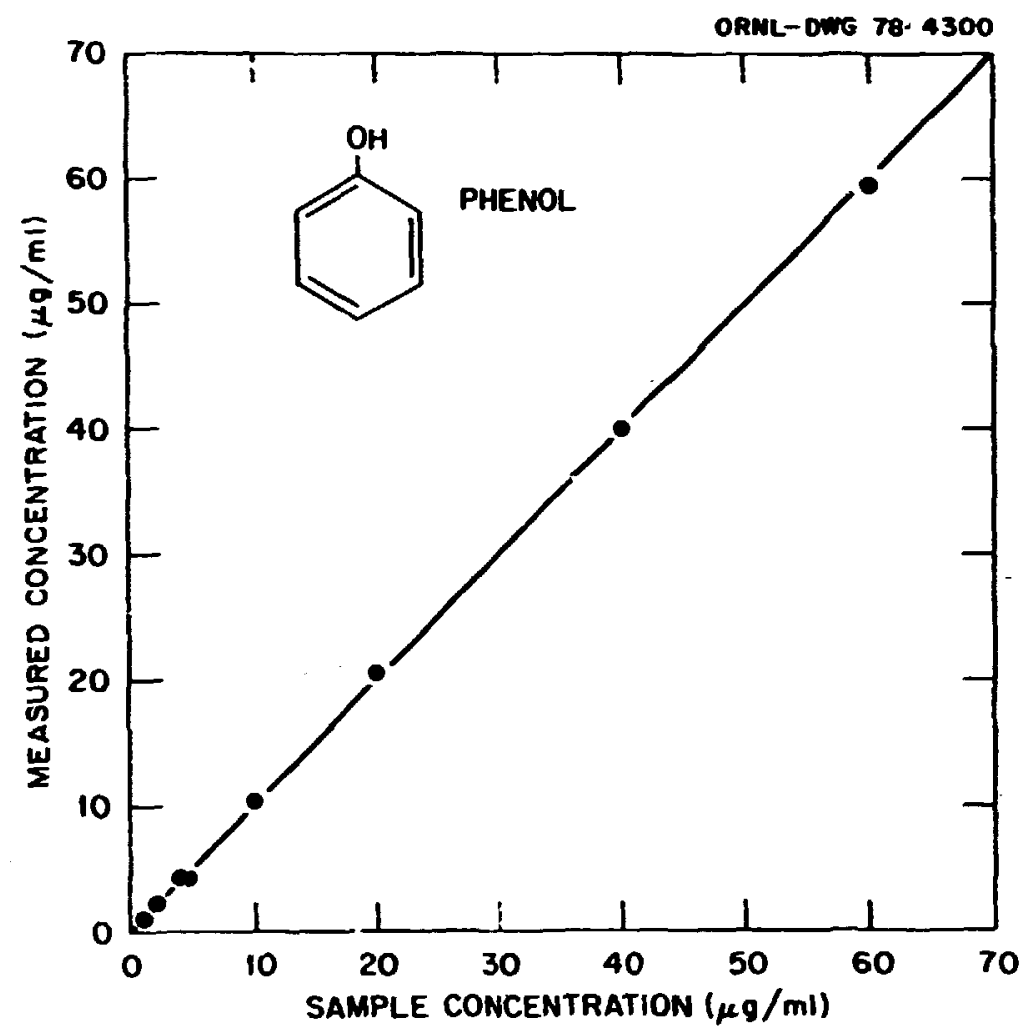

Fig. 21. Calibration curve generated using DUVAS for phenol in water.

( $25 \mathrm{\mu g} / \mathrm{mL}$ ) is compared in Fig. 22 with the second-derivative spectrum of the same sample. The second-derivative response looks almost identical to the pure sample response of Fig. 3 while there is a drastic difference between the direct absorption spectra.

Another potentfal application for DUVAS is coal-fired power plant. smokeplume characterization. DUVAS may prove suitabie for inclusion in an aircraft instrumentation package traversing the smokeplume and mapping concentration proflies of varfous gases. Such features as multicomponent capability, sensitivity, real-time response, selectivity, and instrument ruggedness make DUVAS a promising candidate for such a project.

Among the gases found in smokeplumes which DUVAS can detect with Bub-ppm sensitivity are $\mathrm{NH}_{3}, \mathrm{SO}_{2}$, $\mathrm{NO}, \mathrm{O}_{3}$, and $\mathrm{NO}_{2}$. Encouraging results have also been obtained in trying to measure HONO, an important species in smokeplume chemistry. Figure 23 shows a calibration curve for $\mathrm{NH}_{3}$ 11lustrating that low-ppb concentrations can be measured. These messurements were made with a l-m sampling cell with a total pathlength of $12 \mathrm{~m}$. 

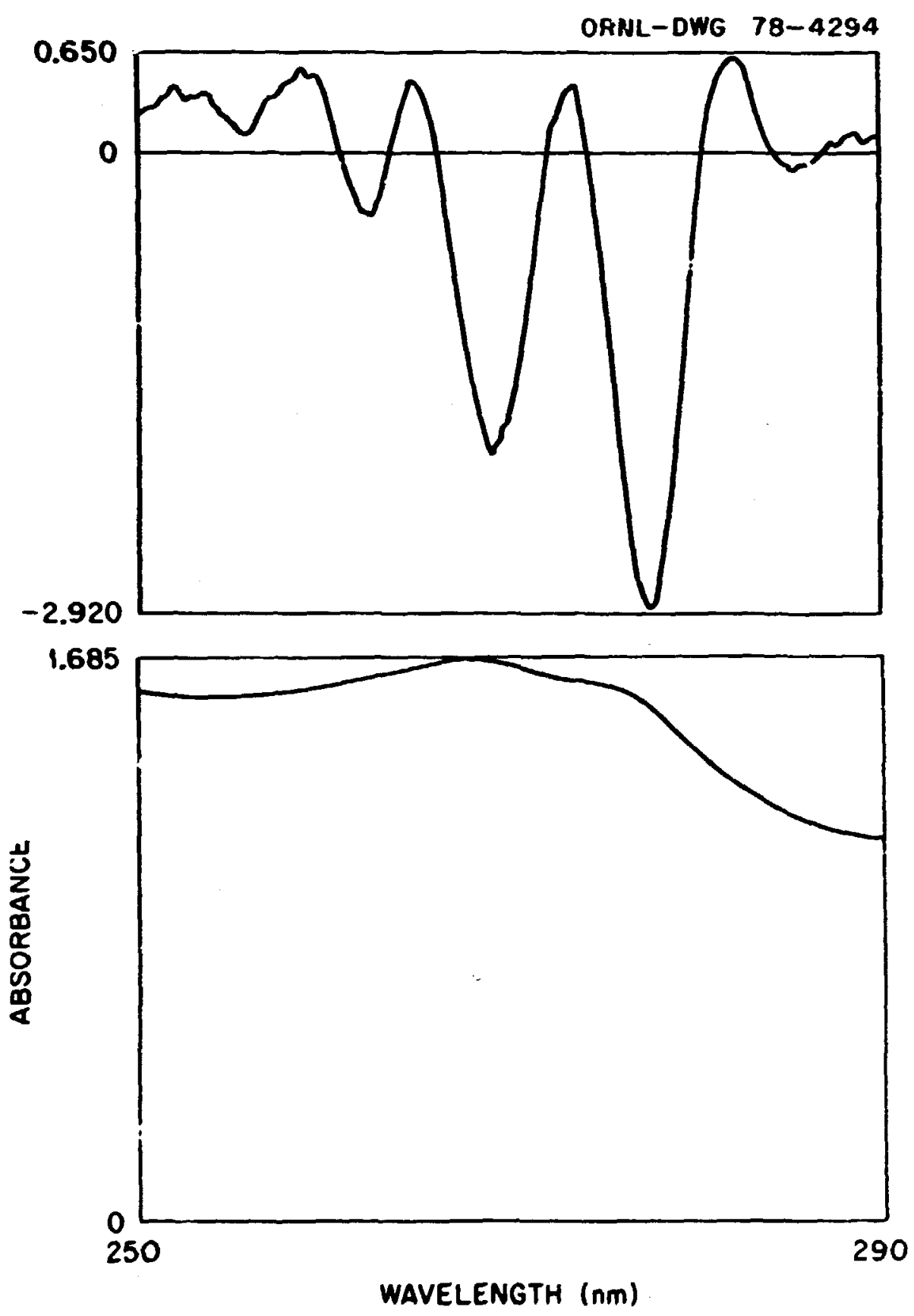

F18. 22. Normal (bottom) and second-derivative (top) spectra illustrating the effect of sample turbidity on the analysis of phenol in a wastewater sample. 

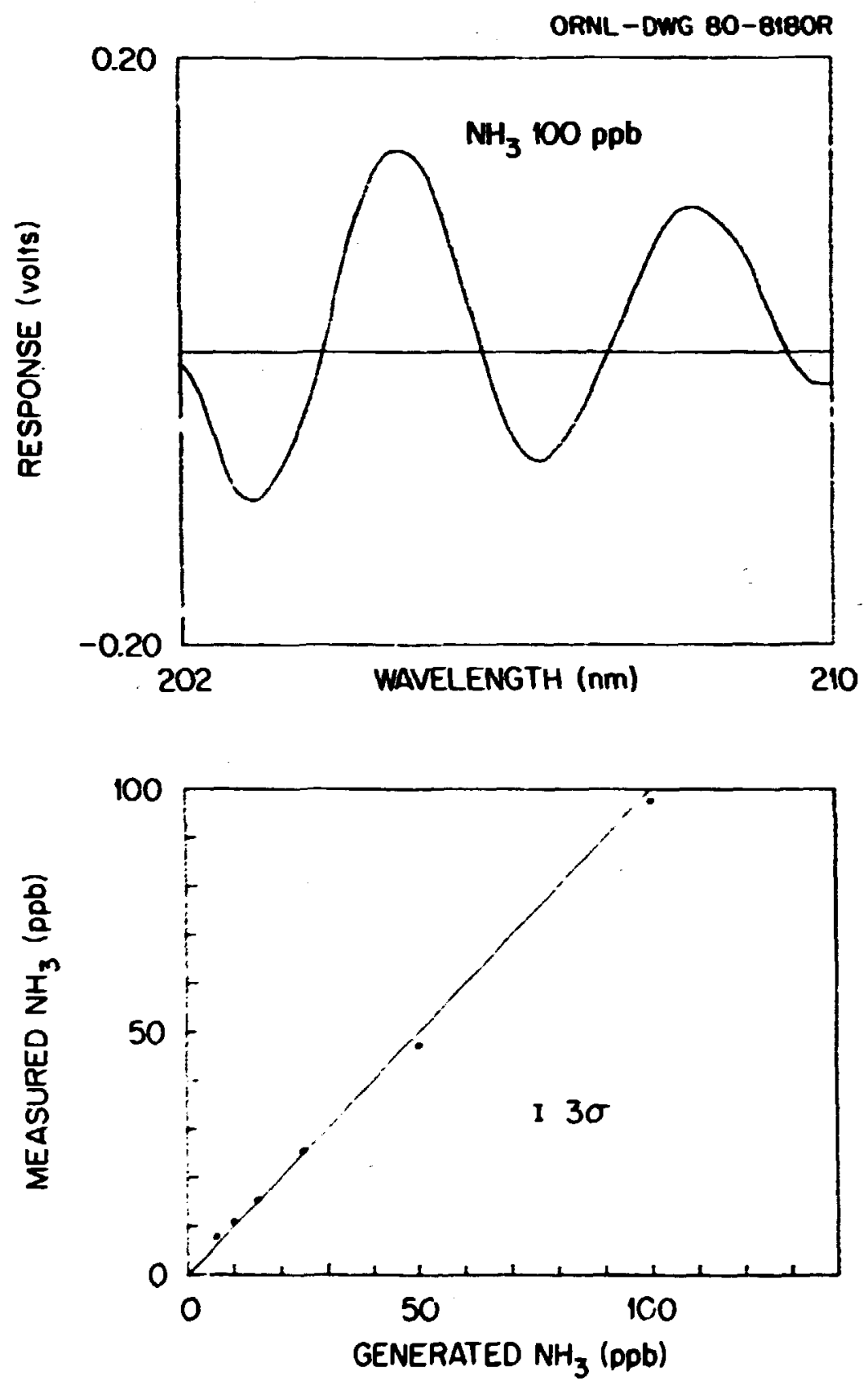

Fig. 23. DUVAS calibration curve (bottom) for low levels of $\mathrm{NH}_{3}$ using a 1-m sampling ce11 and 12-m pathlength and a standard spectrum at $100 \mathrm{ppb}$ (cop). 
A similar project to the smokeplume characterization involves the use of DUVAS as a remote station monitor to measure the same gases found in the smokeplume. Of importance here is the ability of a single multicomponent instrument to replace several independent monitors. Further discussions on feasibility and evaluation of this application are expected with the Tennessee Valley Authority. ${ }^{26}$

Indoor air pollution is an area of health and safety research that is receiving increasing attention as various conservation measures are implemented which tend to increase indoor pollutants. In addition to the above-mentioned gases, DUVAS may prove useful in measuring aldehydes found in the indoor environment. Although the sensitivity for formaldehyde is marginal at best for expected air quality standards, the instrument is quite sensitive to benzaldehyde (low-ppb detection limit). The applicability of DUVAS as an indoor air pollutant monitor will be evaluated as part of a developing program in indoor air pollution characterization.

A final area of application and the primary motivation for the development of DUVAS is as an industrial hygiene monitor for aromatic vapors associated with synfuel facilities. An indication of the aromatic vapors expected from various coal conversion and shale oil products was obtained by flowing an air stream over a sample of the product and diluting the resultant gaseous sample with air for measurement with the DUVAS. ${ }^{\circ}$ The following compounds have been ietected in this manner: benzene, toluene, phenol, cresol, indane, naphthalene, asd methy Inaphthalene. Not all compounds were found in each product, and the relaidive ratios of compounds varied between products. A variety of parameters such as temperature and age of cample, in addit on to the product origin, influence the emission rate from the samples; therefore, a useful comparison between different products is likely to be more qualitative than guantitative. However, results of work currently under way to correlate these parameters are encouraging. As an example of data obtained, Fig. 24 shows a spectrum of vapors sampled above a tar sample from a low-Btu gasifier. The presence of benzene in the sample is clearly evident when compared with Pig. 17.

DUVAS has also been evaluated in field-monttoring applications. Measurements were made at a small benchscale hydrocarbonization unit. 


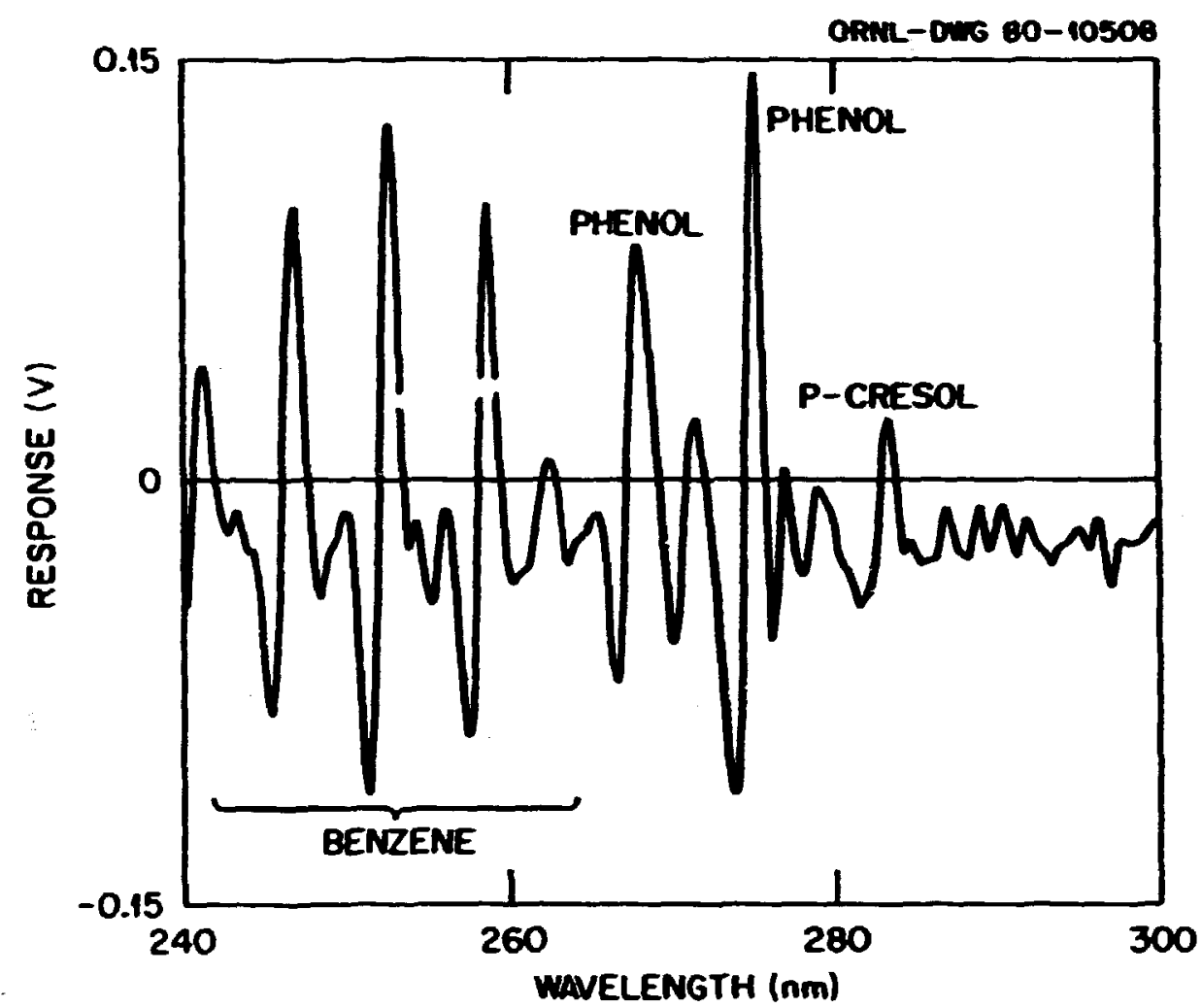

Fig. 24. Spectrum of vapors from a low-Btu gasifier tar sanple taken with DUVAS.

Figure 25 shows a spectrum taken before and after a condensate vessel was opened in the experiment area. A dramatic increase is seen in the concentration of methylnaphthalene. Only low levels $(<0.1 \mathrm{ppm})$ of aromatic vapors were observed during normal operation. Additional field monitoring was conducted at a low-Btu gasifier. A particularly striking example of the real-time monitoring capability of DUVAS was obtained while monitoring near a lock-hopper knife valve. Figure 26 is a plot of the benzene concentration versus time taken using the DrVAS "time" command. 19 Each spike in the spectrum corresponds to the opening and closing or the knife valve. Although the mean level of benzene near the valve was relatively low, the rapid response real-tiwe measurement showed significant concentration excursions. Th1s example illustrates the capability of the instrument in providing real-tim informstion on potential worker exposures, as well as in detecting leaks and other sources of aromatic vapors. Purther fleld evaluation studies are under 

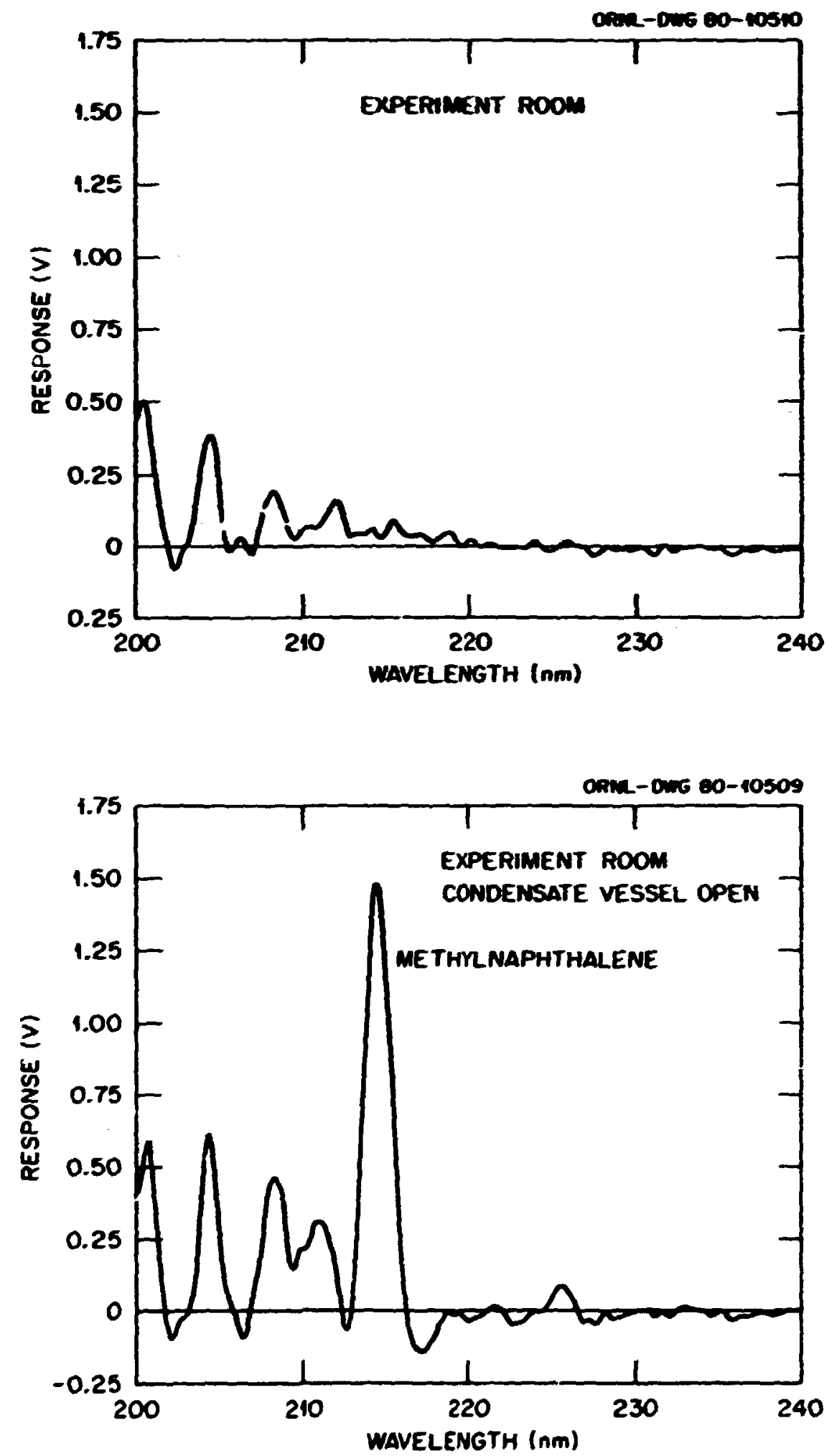

P \pm . 25. Spectrum of room air before and after a condensate vesse 1 is opened taken with DUVAS. 


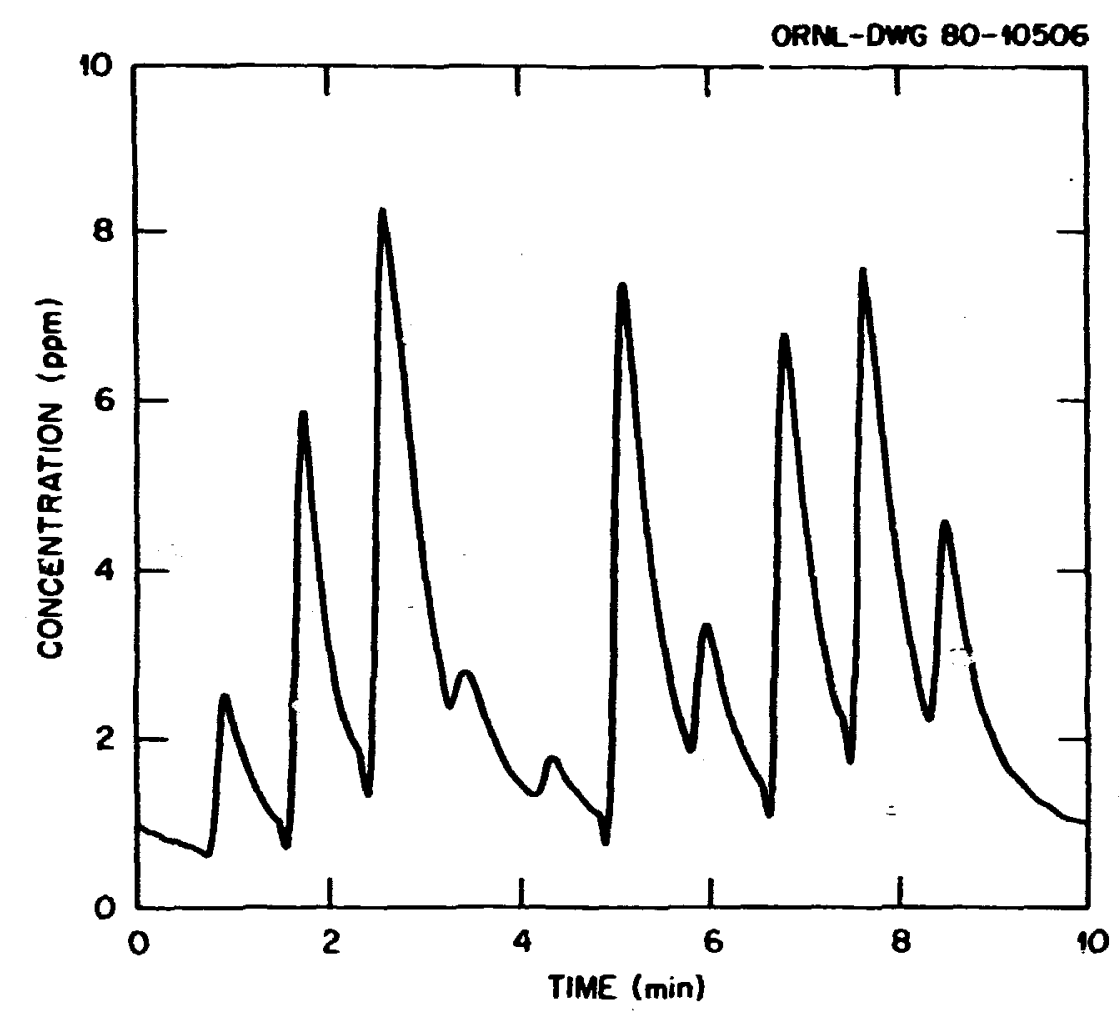

Fig. 26. Plot of benzene concentration versus time near a lockhopper knife valve as measured by DUVAS.

way with trips planned to the University of Minnesota at Duluth low-Btu gasifier, the H-Coal liquefaction plant at Cattletsburg, Kentucky, and the Holston Ordinance facility at Kingsport, Tennessee.

The preceding examples of DUVAS application illustrate the diversity of projects where the instrument can be utilized. Some of the projects may prove not to be feasible on a routine basis while new projects will likely be recognized. In any event, DUVAS has already proven to be a rellable, highly ve satile tool for measuring trace pollutants in a variety of health and safety problem areas. 
FUTURE WORK

Several engineering design and evaluation projects are under way to assess the feasibility and desirability of making sone rather drastic design wodifications. These modifications are aimed primaril; toward reducing the cost, improving the reliability, and reducing the size and weight of the DUVAS. Most of the changes considered will utilize wore of the capabilities of the instrument microcomputer. In addition to the reduced component count and increase reliability of microprosessor implemented functions, modifications and revisions can easily be aade by sioply reprograwing the EPRous containing the DLVAS control program.

The first and wost drastic change would be to implement the secondderivative function using the rumerical wethod inscead of wavelength modulation. Using current microcomputer systems, a derivative filter can be implemented eliminating th. need for an external computer to perform tis function. A major advan:age of this approach would be the elimination of the vibrating mirror in the mnochromator, the required machining work to modify and install she mirror in the monochromator, and the associated mirror drive circuitry. The harmonic detection circuitry would also be eliminated leaving a greatly simplified signal conditioning circuit. A potential disadvantage of this approach is the $10 s s$ of ability to dwell at a specific wavelength. To maintain this capability, a psuedo "dwell" feature is implemented where the monochromator is scanned a few nanometers about the specified wavelength in order to form the second derivalive. This function repeats every few seconds to provide an essentially continuous dwell. A detailed comparison of the performance between the two methods will be made.

The second significant modification being considered is the replacement of the photomultiplier tube and its associated high voltage supply with a solid state photodetector and high-gain, low-noise amplifier. This substitution would eliminate one of the system's power supplies and reduce the size needed for the detector. A potential limitation may be that even with a high-gain amplifier the sensitivity of the photodetector wil.1 be insufficient to allow use of the narrow monochromator slits and long pathlengths needed for optimum instrument operation. 
A third wodification being evaluated is the use of relatively narrow wirrors in the multipass sampling cell with the cell being of narrow rectangular design and folded back foraing one side of the instrument. This configuration will significantly reduce the size of the DUVAS. Another feature considered is the addition of heating elements within the cell to facilitate the cleaning of the cell when a $10 \mathrm{~N}$ boiling point compound is measured. A final advantage of this cell design would be a fast response time due to reduced cell volume.

Additional features expected to be incorporated in a new design include an autocalibrate on powerup to a sharp enssion line of the deuteriun lamp. This will elininate the need for the operator to insert a calibration sample and to initiate manully a wavelength calibration upon startup. Another feature being considered is the incorporation of all functions, including laxp and stepping wotor power swicches, under microprocessor control. All functions would be controlled by entering commands through the microcomputer keyboard. This allows the instrunent to be operated totally by remote control since comands can be entered either through an external computer or through the keypad. This feature may prove to be particularly useful for remote locations where data and commands can be commicated via telephone lines. Another function to be included in the new program is a comand to provide direct output of the instrument response in ppi for a limited number of compounds. The appropriate wavelengths and a calibration constant would be entered into the instrument, with concentrations being printed at prescribed intervals. These values could also be compared with a preset value to activate an alarm if the level is exceeded.

More features will likely be implemented as work on these design modifications progresses. A prototype DUVAS incorporating these changes is now under development. The result of the work should be an Instrument with lower cost, reduced size, Improved rellability, and increased power. 
The preceding sections have described the theory, the desiga, the evaluation, and various applications of a derivative Uv-absorption spectrometer. A prototype DUVAS has been constructed and evaluateá for use in real-tine, field-portable monitoring of aromatic vapors at coal conversion facilities. Many of the desired characteristics of an industrial bygiene instrument such as portability, multicomonent capability, selectivity, and sensitivity have been demonstrated. The instrument should prove useful as an industrial hygiene tool both for area monitoring and for locating leaks.

In addition to monitoring for aromatic vapors, the instrument will likely be used to weasure low levels of $\mathrm{NH}_{3}, \mathrm{SO}_{2}$, and $\mathrm{NO}_{x}$, along with other narrow absorption band gases. Future applications will likely invo:ve some monitoring for indoor air pollutants. Measurement of wastewater streams from synfuel plants in an on-1ine mode of operation is being investigated.

Further improvements and modifications are under development which will lower the cost, increase the instrument capability, and reduce the size and weight. These parameters are particularly important in a field-portable instrument. The DUVAS described in this refort helpa fill the need for multicomponent real-time monitors of hazardous compounds associated with a variecy of energy related technologies. It should prove a useful addition to the monitoring instruments available to the industrial hygienist and environmental scientist in evaluating the exposure of man and the environment to these potentially hazardous compounds. 


\section{ACKN XILEDGENTS}

The authors wish to thank R. A. Todd, J. H. Thorngat:, and T. G. Hatthews for their contributions to the DUVAS project. Ack=wledgment is also ade of the encouragement and support of R. B. Gammage and the Health and Safety Research Division management for this work. 


\section{REFEKENCES}

1. v. J. Hammonà and w. C. Price, J. Opt. Sco. Am. 43, 924 (1953).

2. A. Giese and C. French, Appi. Spectrose. 9, 78 (1955).

3. G. Collier and F. Singleton, J. Appl. Chem. 6, 495 (1956).

4. G. Borfigholi and P. Brovetto, Appl. Opt. 3,1417 (1964).

5. A. Perregaux and G. Ascarelli, ALT. GQt. I, 2031 (1969).

6. D. T. Willians and R. N. Hagar, Ippl. O:t. 9, 1597 (1970).

7. R. N. Hagar, AnaZ. Chem. 45, 1131A (1573).

8. T. C. O'Haver and G. L. Green, Aral. Chem. 48, 312 (1976).

9. R. N. Hagar and R. C. Anderson, J. Opt. Soc. Am. 60, 1444 (1970).

10. E. Gunders and B. Kaplan, J. Opt. Soc. Am. 55, 1094 (196j).

11. A. R. Hawthorne and J. H. Thorngace, Appl. Opt. 17, 724 (1978).

12. A. K. Hawt lorne and J. H. Thorngate, App Z. Spectros. 33, 301 (1979).

13. A. R. Hawthorne, J. H. Thorngate, R. B. Gammage, and T. Vo-Dinh, "Trace Organic Analysis: A New Frontier in Analytical Chemistry," Nat. Bur. Stand. U.S. Spee. Fibl. 519, 719 (1979).

14. J. E. Cahill, Am. Lab. 11, 79 (1979;.

15. G. L. '́ree, and T. C. O'Haver, Anal. Chem. 46, 2191 (1974).

16. G. Boldini, E. Grilli, and M. Gozzi, Appz. Ort. 14, 2687 (1975).

17. F. R. Stanffer and H. Sakori, Appl. Opt. I, 61 (1968).

18. A. R. Hawthorne, fmerican Industrial Hygiene Association Joumal (In press).

19. T. G. Matthews, A. R. Hawthorne, and R. B. Gammage, submitted to Analytical Chemistm.

20. J. L. Repace and A. H. Lowrey, Science 208, 454 (1980). 
21. H. M. Braunstein, E. D. Copenhaver, and H. A. Pfuderer (eds.), Environmental, Health, and c'ontrol Aspects of Coxl Conversion: An Information Oremiew, ORNL/EIS-94 (1976).

22. Recommended Heaith and exfety Guidelines for Coal Gasifiuation Pilot Plant.s, DHEW (NIOSH)-78-120, U.S. Department of Health, Education, and Welfare, Washinrton, D.C. (1978).

23. p. C. Weast (ed.), Handbook of Chemistry and Physizs, CRC Press, Boca Raton, Florjda, 1977.

24. R. B. Gammage, Proc. Symp. on Assessing the Industrial Hygiene Monitoring Needs for Coal Conversion and oil Shale Industries, BNL 51002 (1979), Pp. 173-88.

25. A. R. Hawthorne, Review of Srientific Instmuments (in press).

26. R. B. Gammage, A. R. Hawthorne, and T. G. Matthews, ORNL Seed Money Report (1979). 
Appendix A

LIBRARY OF SECOND-DERIVATE SPECTRA

49 


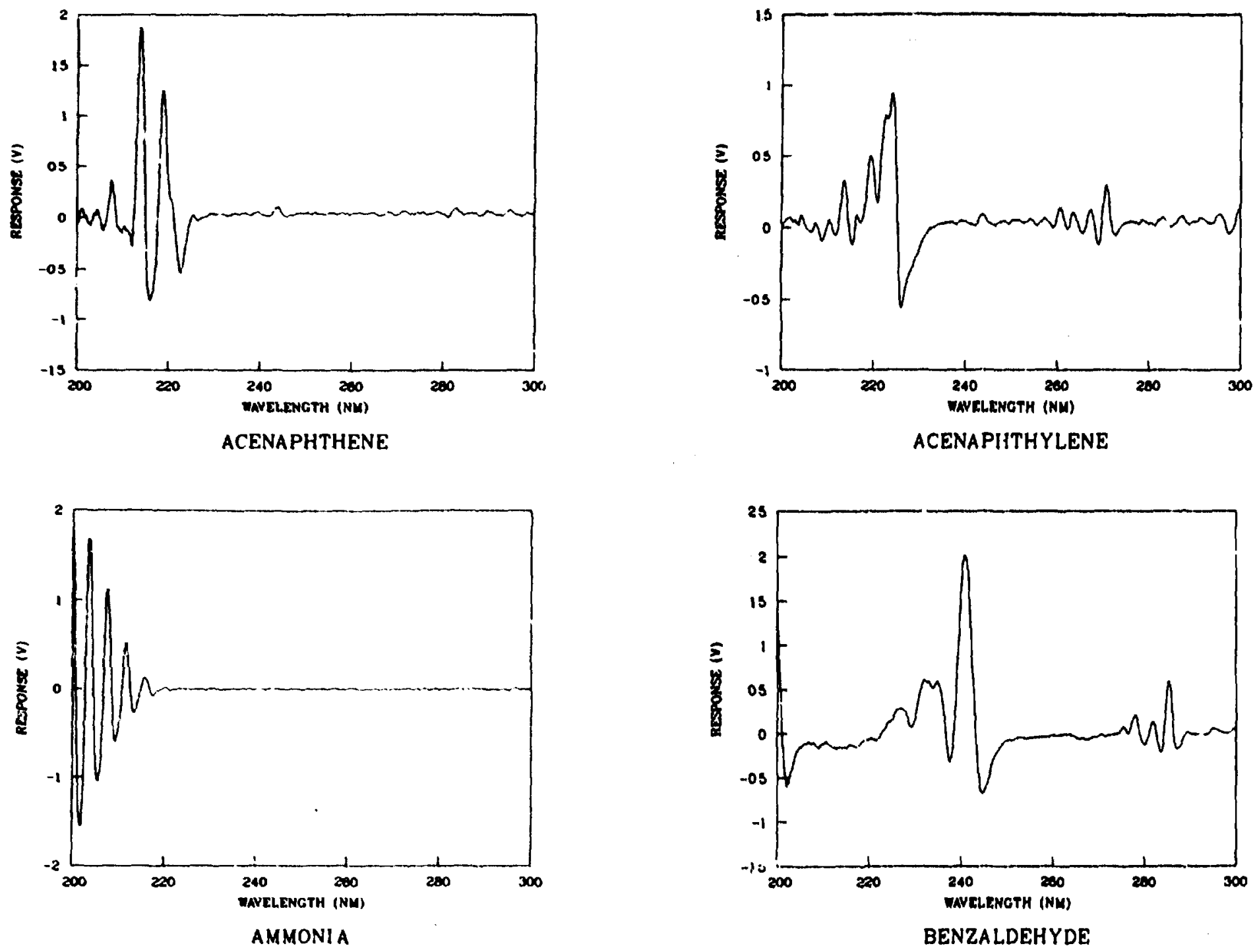

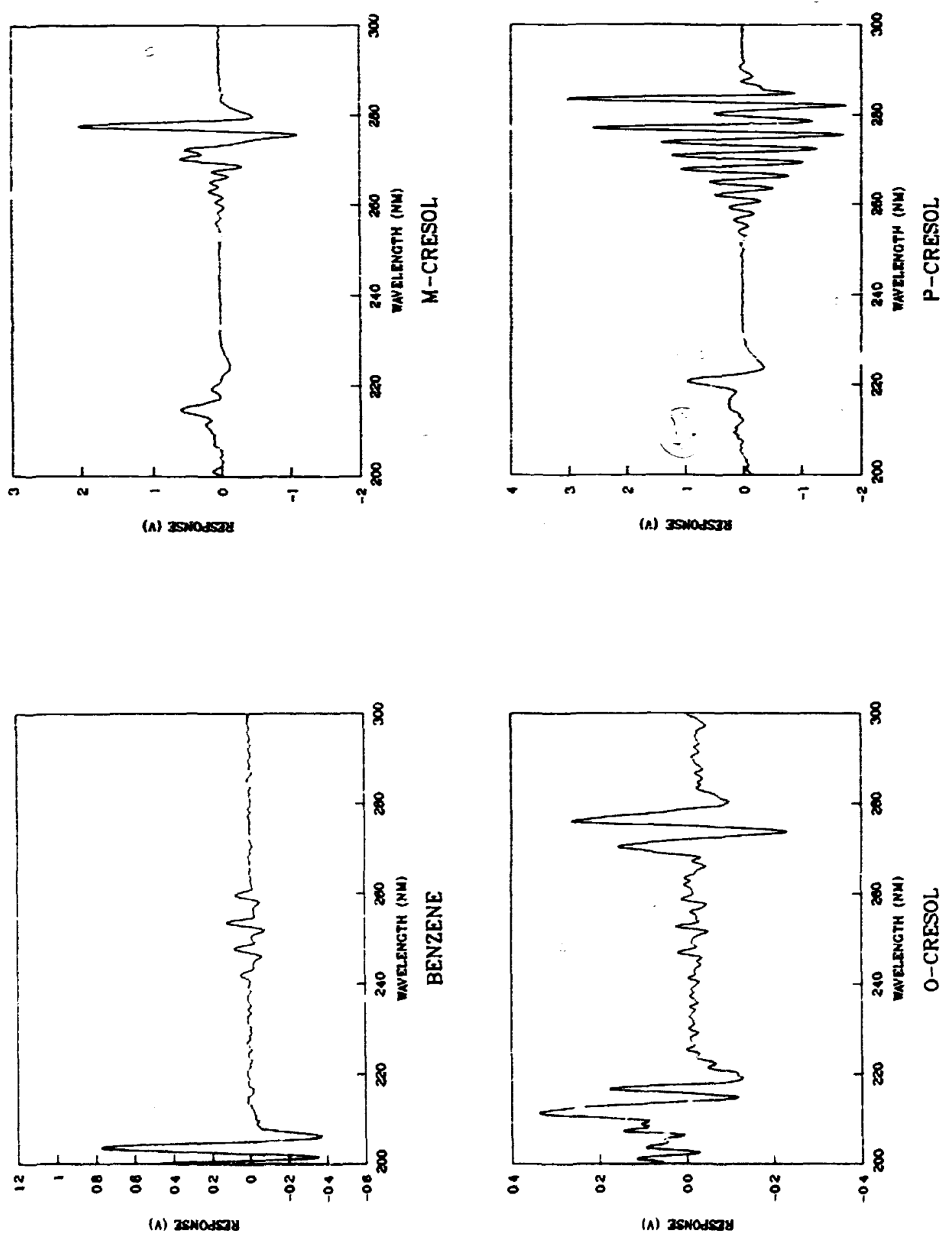

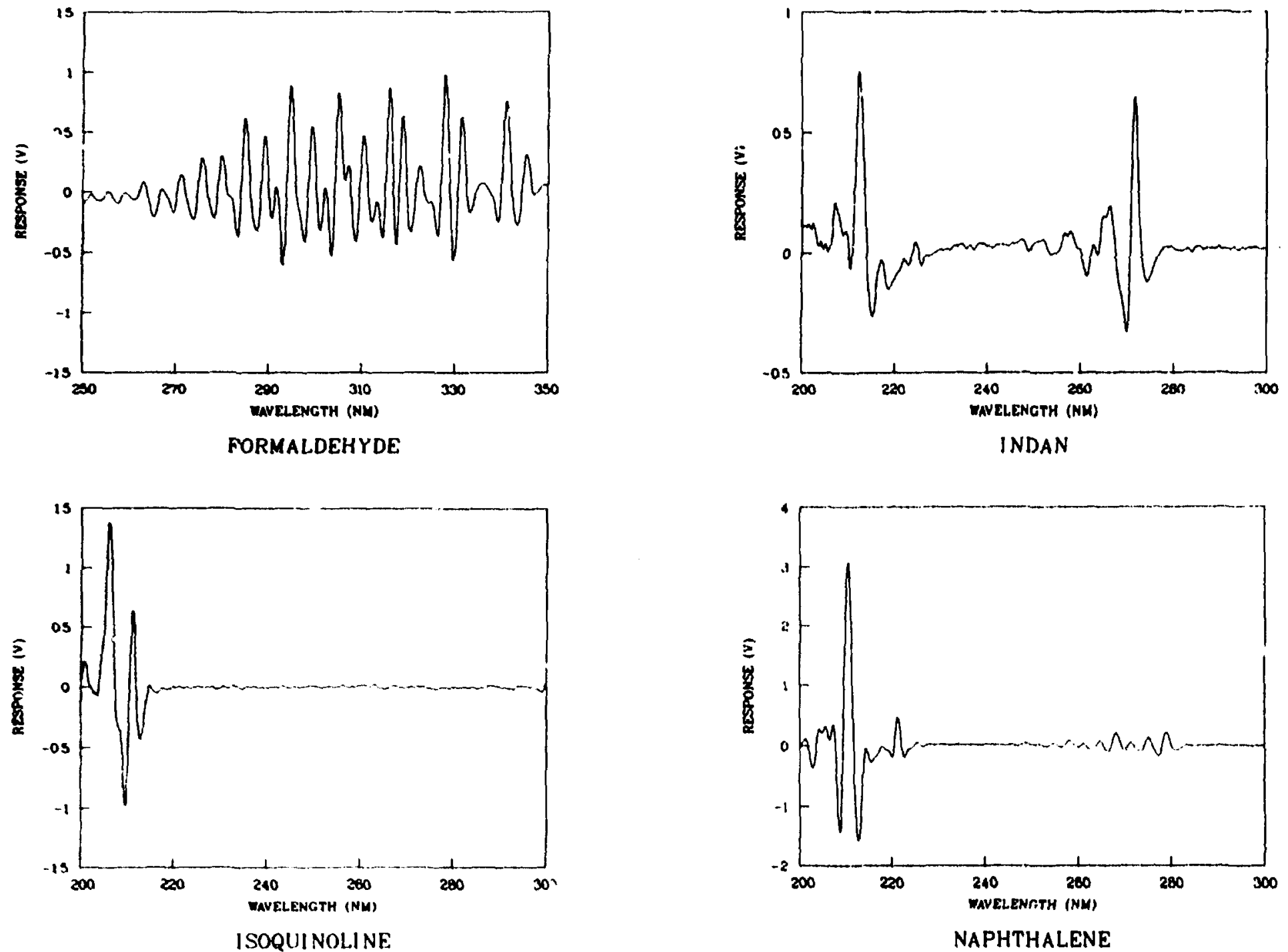

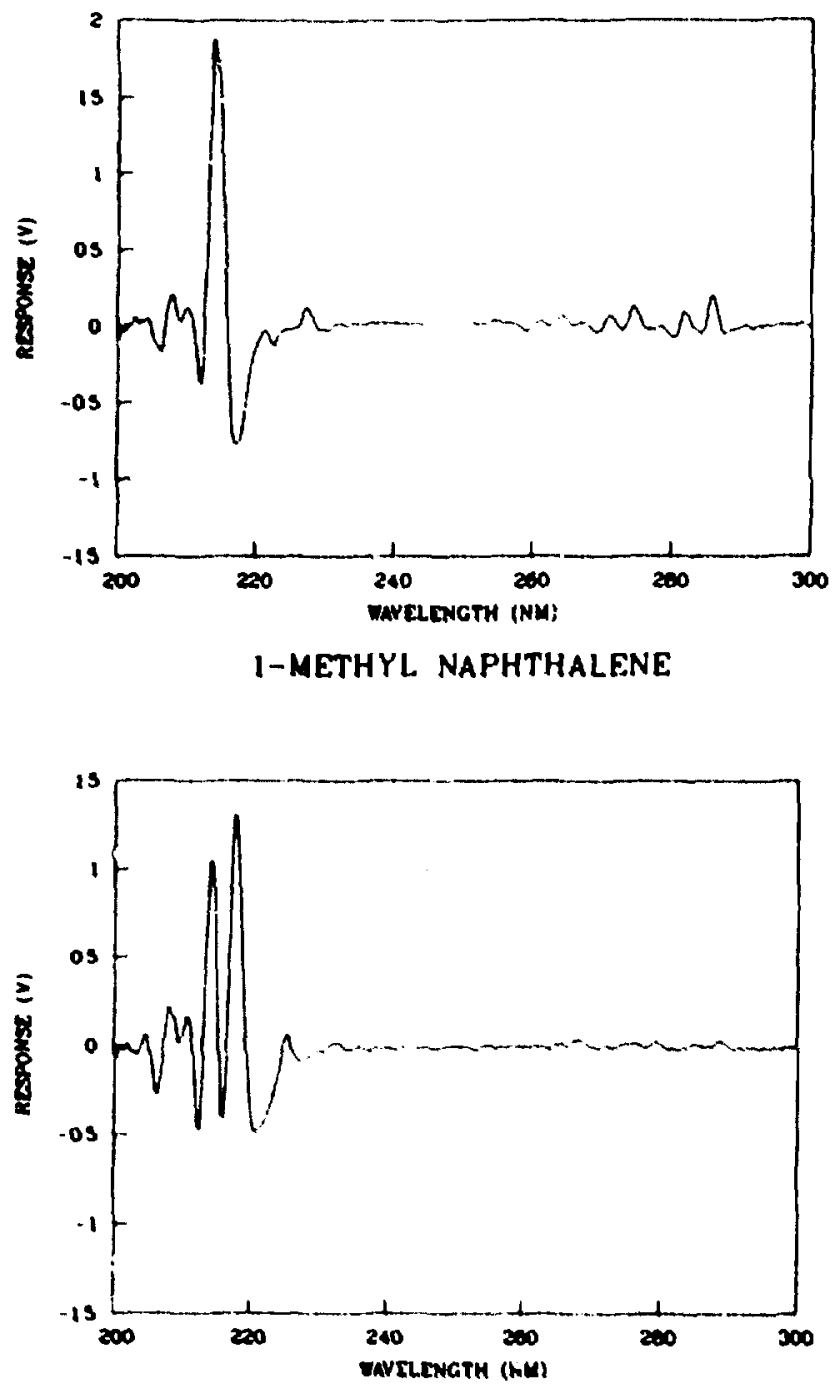

1.2-DIMETHYL NAPHTHALENE

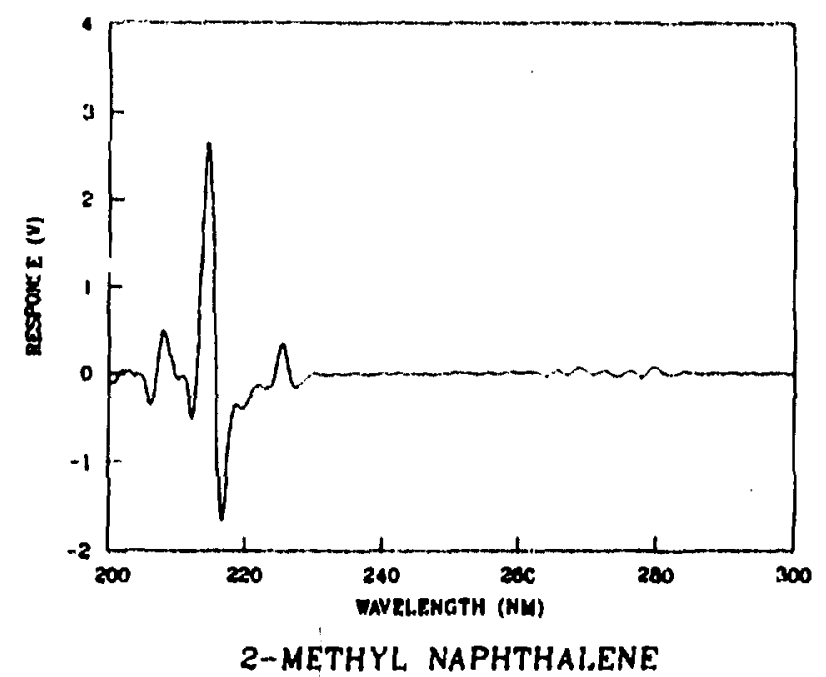

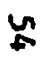

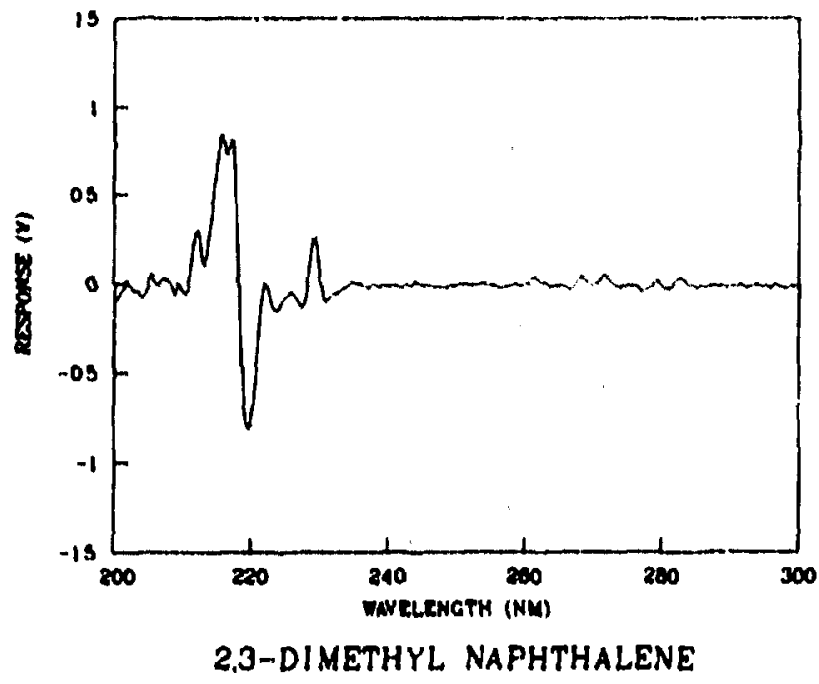



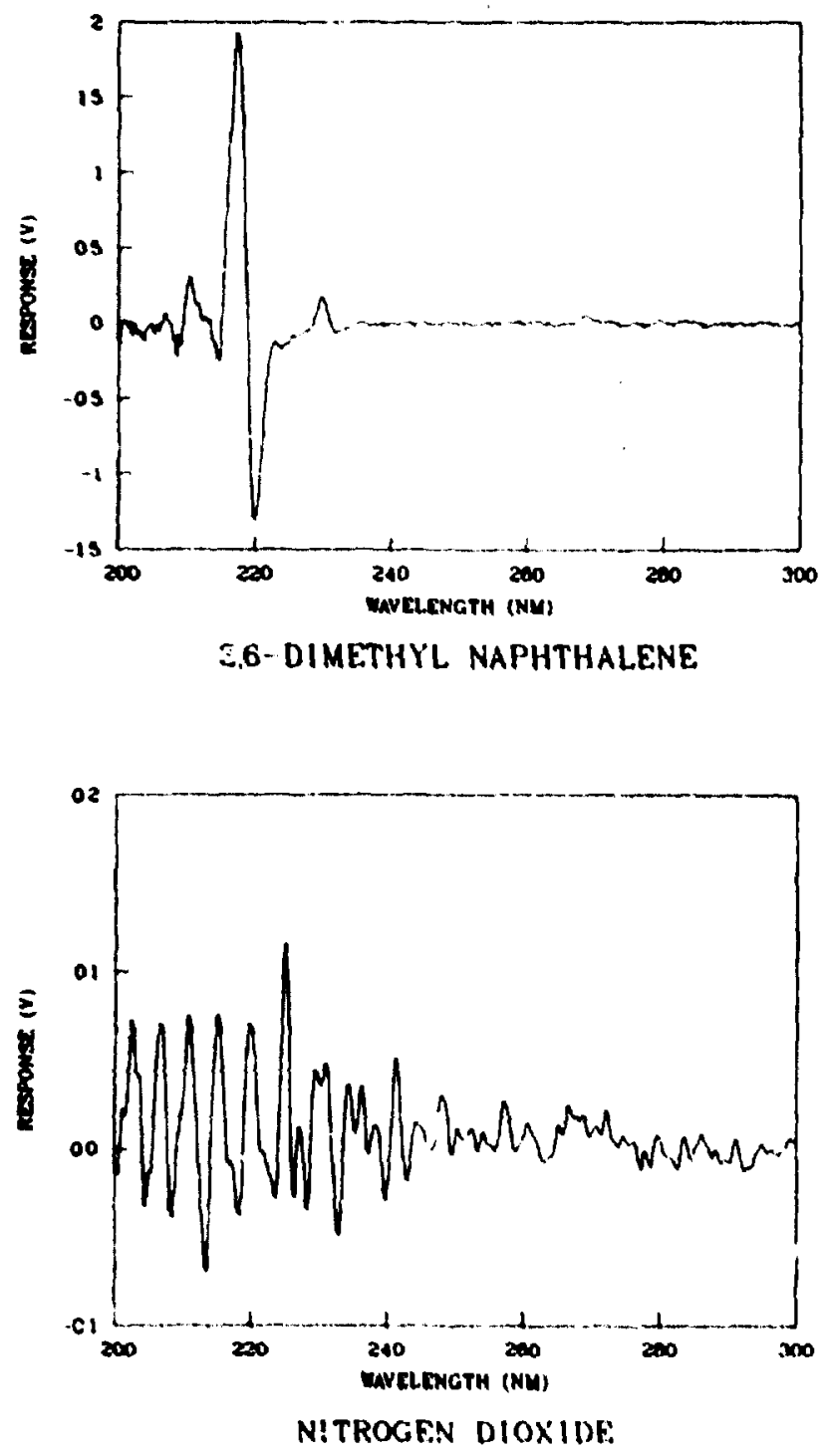

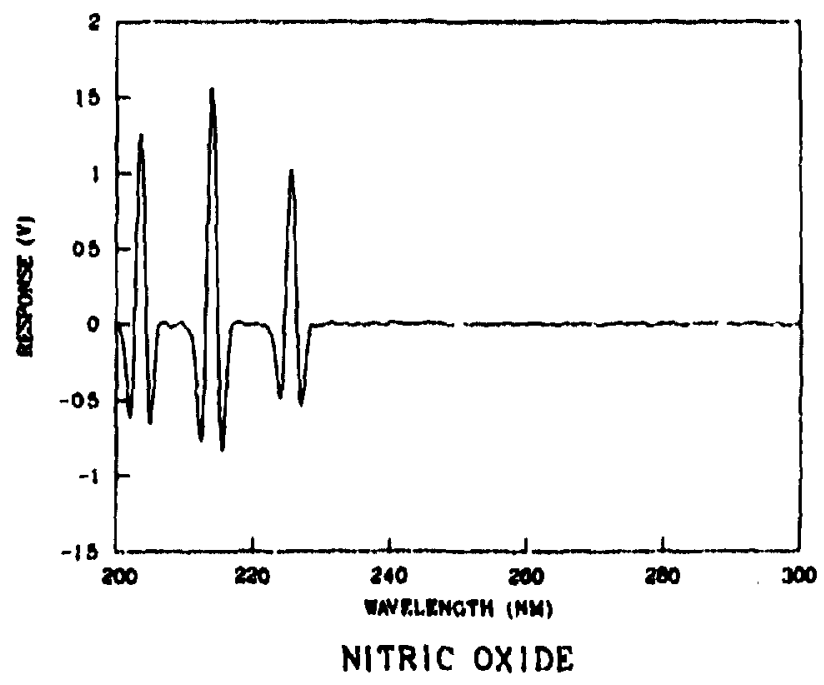

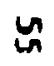

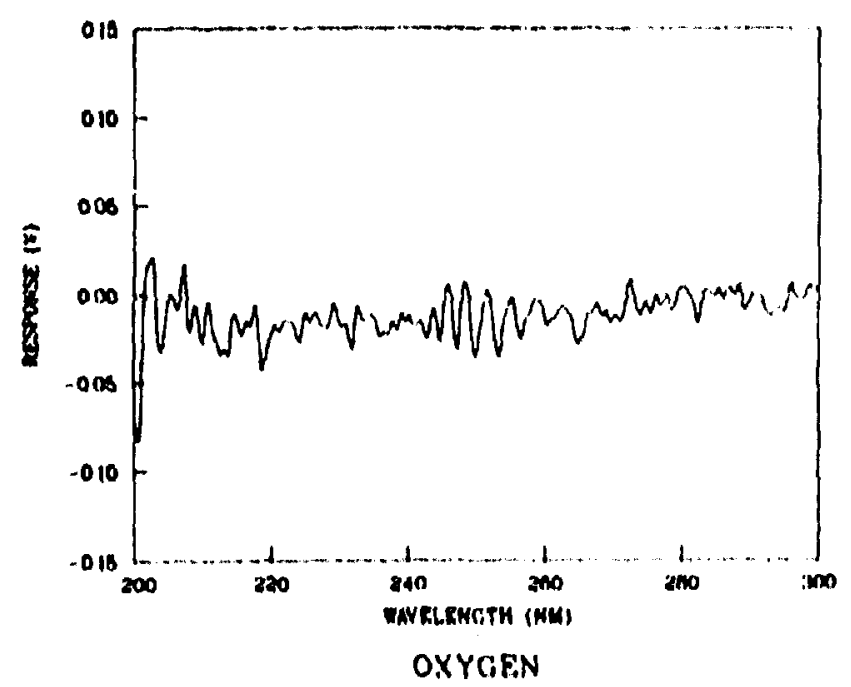



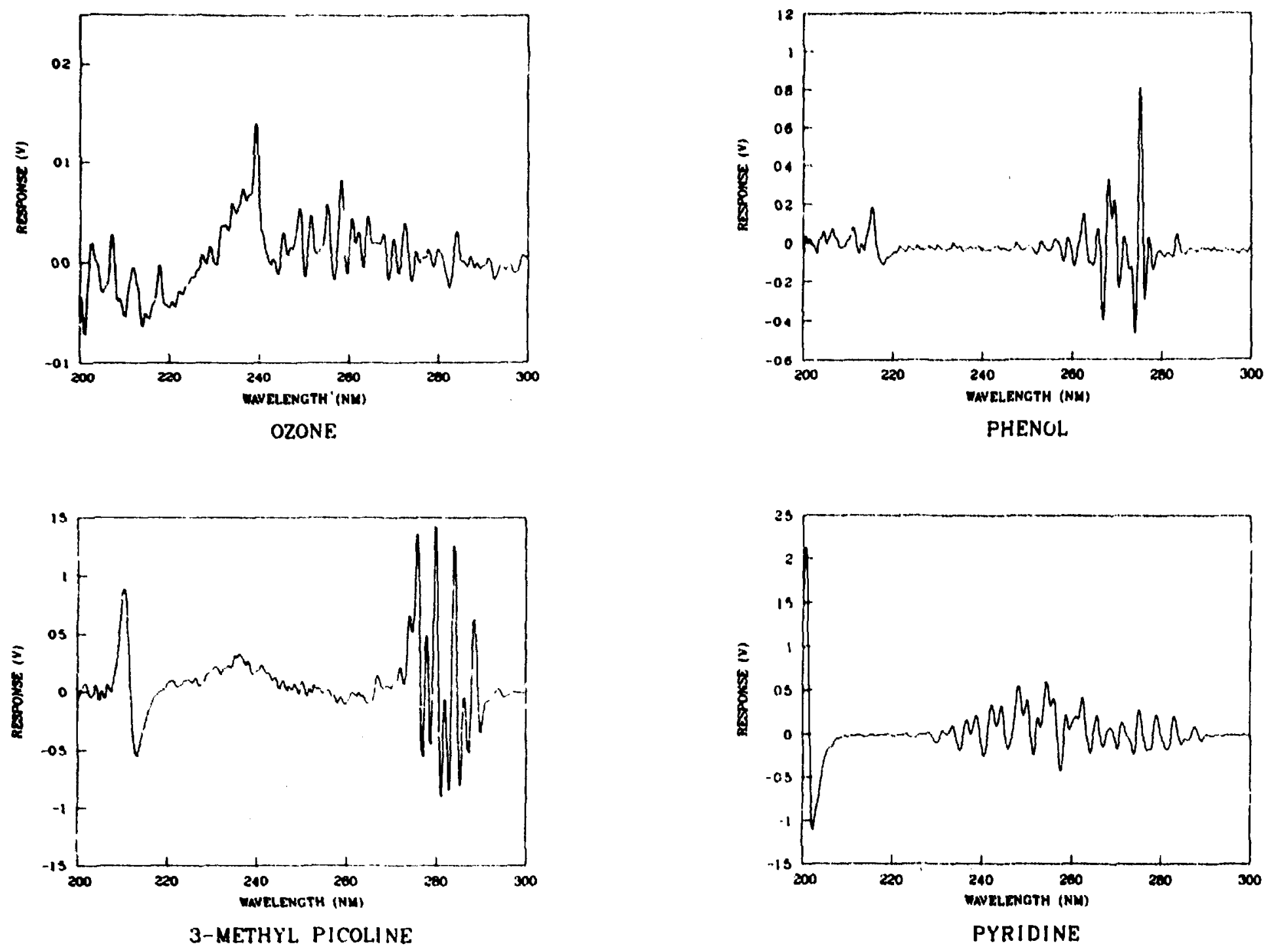

ะ 

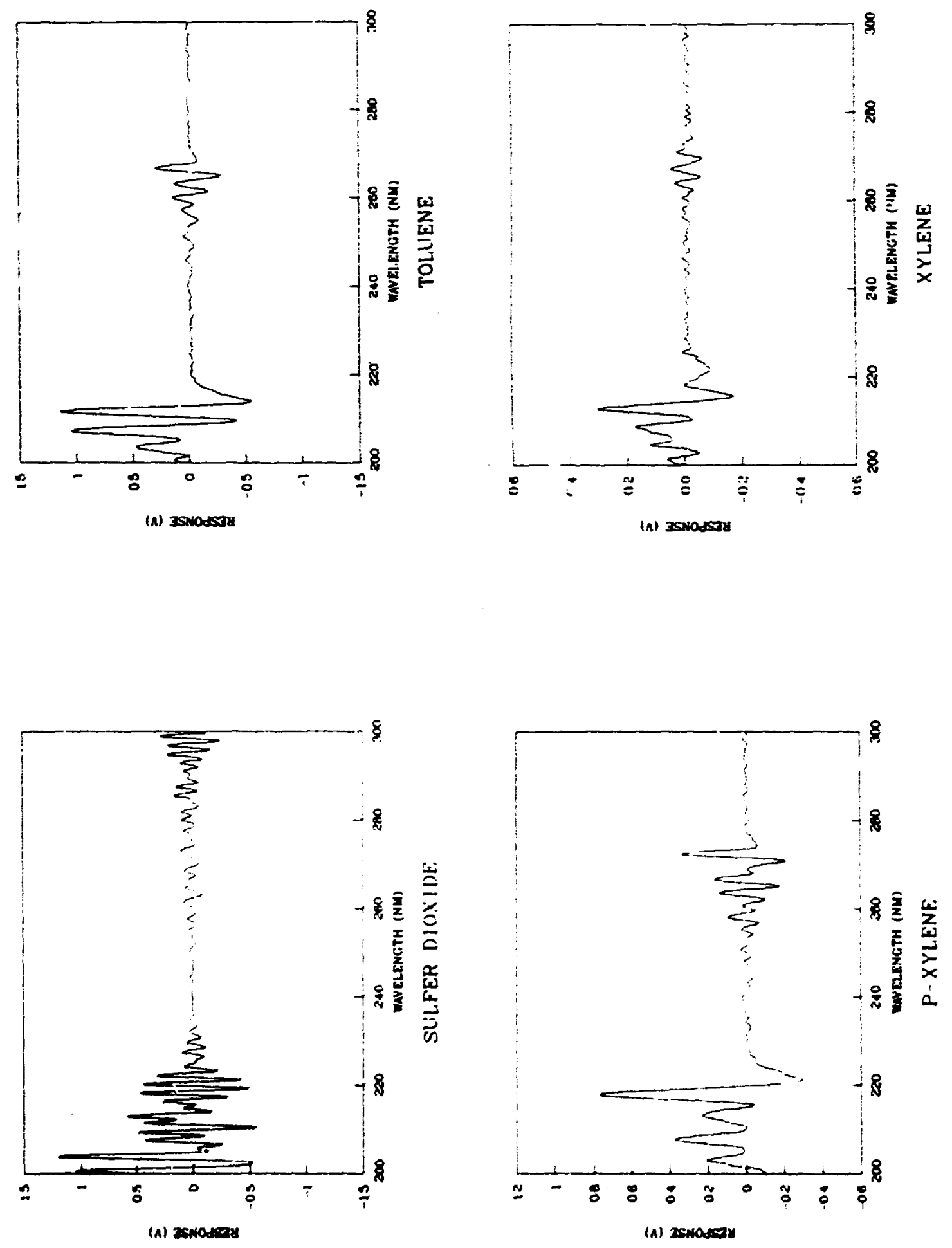
Appendix B

DUVAS PROGRAM LIST ING 


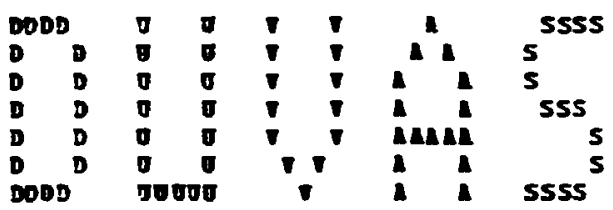

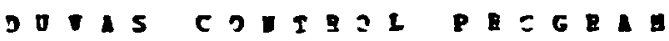

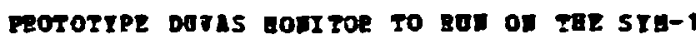

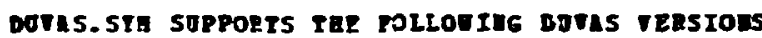

VegSTON 1: 1 ST2P $=2.5$ ALGSTROAS

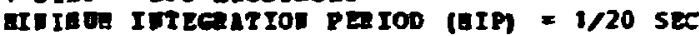

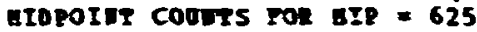

TERSIOI 2: 1 sTeP $=1$ Ansstzo

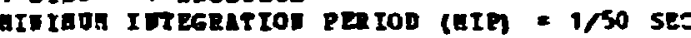

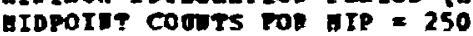

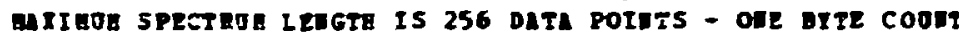

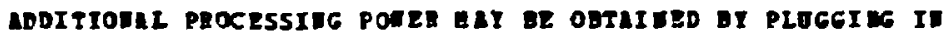

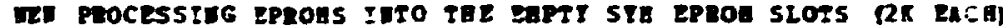

I/O LITES TO EITEEHI DETICES

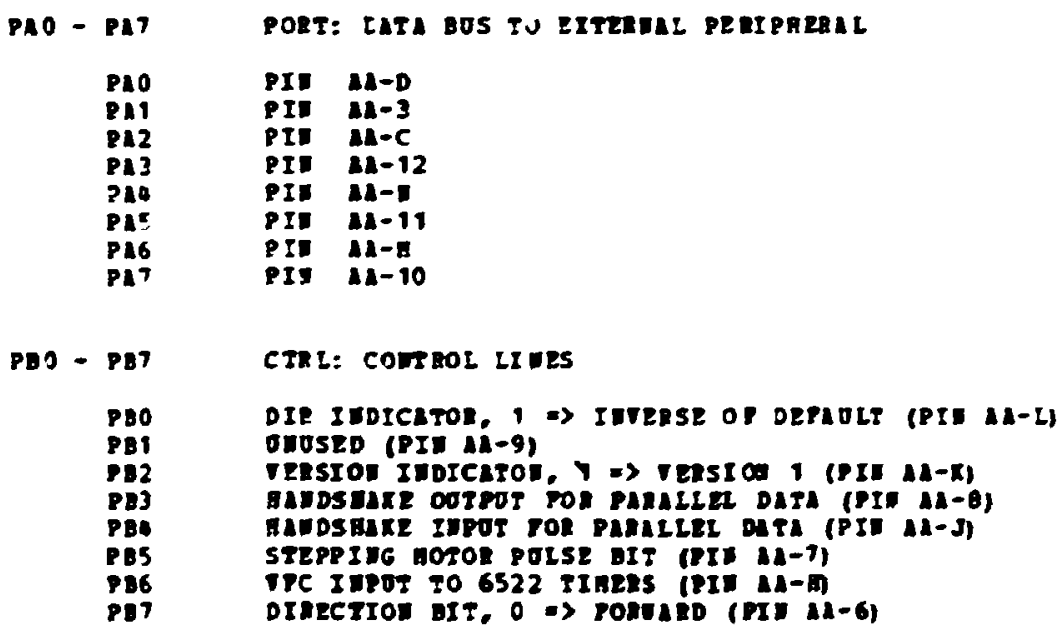


Her rearet

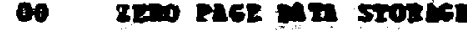

5TH-1 STSTH stac

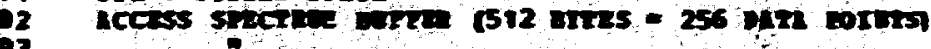

83

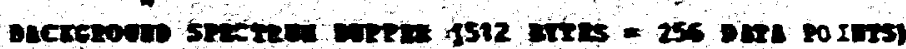

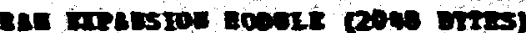

$\therefore-$

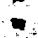

$-$

6

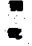

erenisecen th

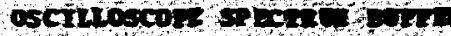

Chetit

$-\infty+a$

$\operatorname{los} \operatorname{cr}_{-2}, 1, \rightarrow n$

0004

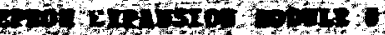

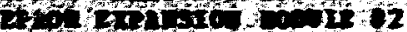

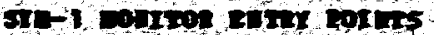

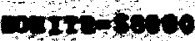

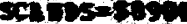

$-4+1=501$

stersonitin

$x+3 x+250$

$10=5072$

crenterast

coondesesa

140.30223

moriestrar

westerean?

cyosenis

Desporesero

wroestc4s

issesces

saIeshy

introget?

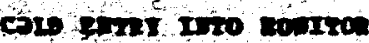

orixt ron aser.

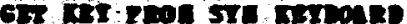

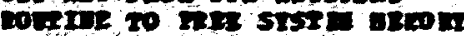

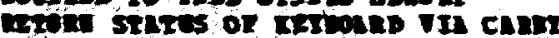

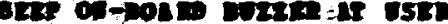

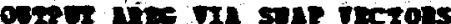

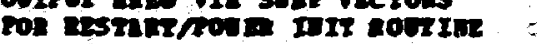

stip verons ror st

sit it Buts ber

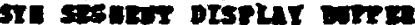

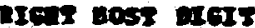

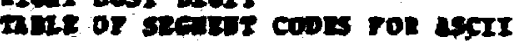

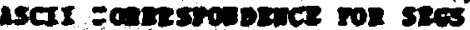

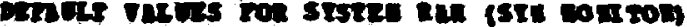

arienc20

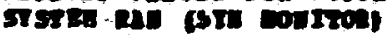

Wo vIL DETIIETOTS

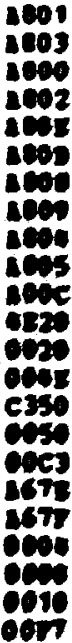

wresacs

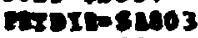

Crimesneos

CuBso 18002

Lissese

careser.

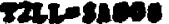

ctalostas

interseses

Ieponos

ient ate

thes

insotere

incouncer

xn220 $=350$

itionoses

ic2:10:3

10900687

Iats-60\%

actorese

anbroser

HeTbetso

mingerin

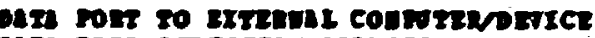

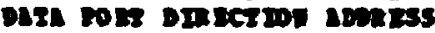

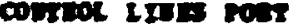

conat rose bersion

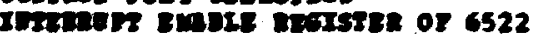

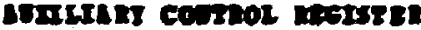

III 2 Lexe IT

III: 2 cent in:

rat itsen to

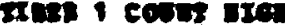

He ro th 01 - ro enssite Iprima

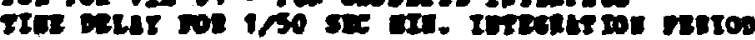

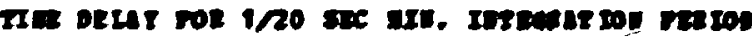

IRe un revel

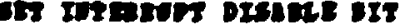

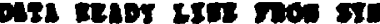

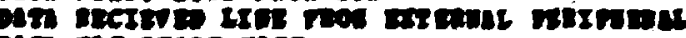

ars we mer inge 
- aso calrongror baratrous

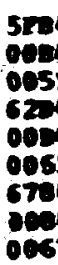

$\cos =20^{\circ} 00^{\circ}$

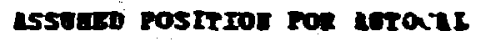

colicus

coneresse

Nein $=25300$

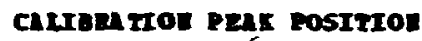

canters

$+2025500$

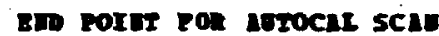

resunesou

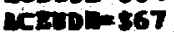

move oepromons

nd $12=55$

1.0 Tras

Doperas

Cars $=2000$

Crez-spose

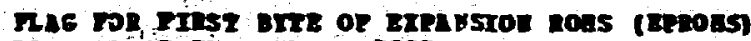

Dive

obs

cous

Dere

CIDT $=3600$

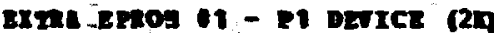

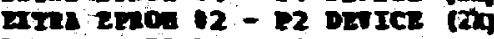

Ra cosales erentsiol

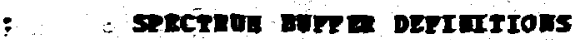

coses

002

0oos

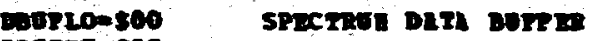

bovar $=52$

-CLEdLatoo

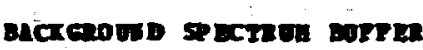

DCREDF $=$ ses

AI ID DISRLAT CODE Dertergrots

00847

$c=500$

Cases2

Laroosese

0o22

0043

000

0032

0023

opore

$00 \mathrm{se}$

0003

0020

$20103=52$

Cisi: 143

GOKET $=500$

An: $=932$

rituresz

arcosese

CPretase

GUERTESO3

aIdoses20
CODE TOL CO KI

cose ros ca ret

CODE ron - at

copr ron $D$ - Deciant porth
CODE JoL ASCI DEIUL potat

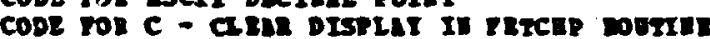

cope ron wo rat bepeses

cove ron niche renor $(-)$

sefitir cobt wor 2 monet

secitis cobe pos truos

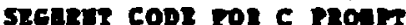

segted cool ros 7 rospr

coderon - art 


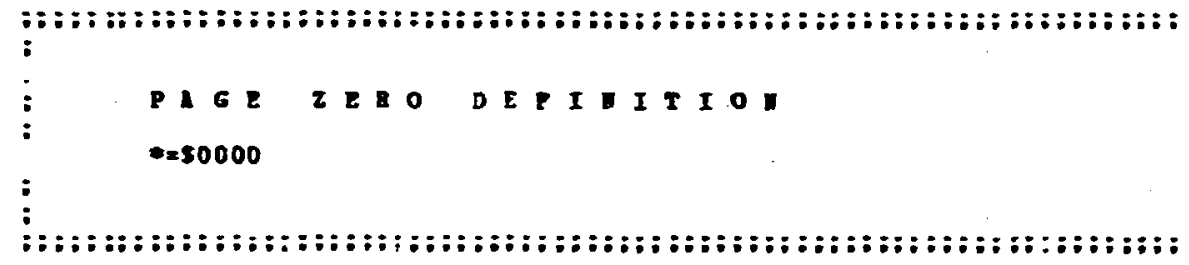

DASTE -BITE 0 RESET SETS THIS BTTE TO \$6F

: SPECTROG PARLAETERS

$\begin{array}{lll}0001 & 20 & 52 \\ 9003 & 28 & 03 \\ 0005 & 19 & 00 \\ 0007 & 64 & 00 \\ 0009 & 01 & 00\end{array}$

PRBA

STER - DORD 20000 STABT OF SPECTROM (*10)

LEI - WORD 1000 LEIGTE nP = ELCTROA

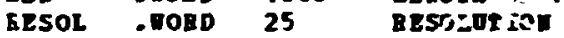

SPED TORD 100 SREED OF SE ETROAETER

ATEI -TORD 10 ITIEUULIOU

6001

0002

0003

0004

000

0008

$S=8 T L=5 T R T$

STRTE=STER+1

LRERO=LEI

ZETEI =LEL+

SP EDL =SPED

SPEDE =SP ED 1

000820 0?

00002800

0008 0100

30110500

000B

000.

OOOD

OOOZ

not1

0012

001300

001400

001520 पE

0017 ZE 03

00191900

00186400

00ID OL 00

001800

002000

002100

002200

002300

002400

002500

002600

002700

$0028 \mathrm{co}$

002900

002100

002800

$002 \mathrm{CO} 0$

002000

002800

FORELTTED SPECTROA PABN:-:TERS

GCPIRE

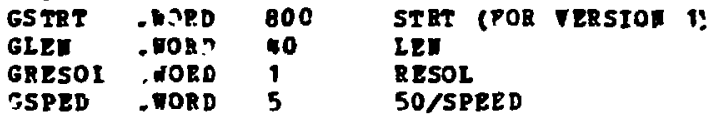

GSTBT L=GSTRT

GSTRT $E=$ GSTAT + 1

GLEILCLER

GLENB I=GLEH+1

GSPEDIEGSPED

GSPED B=GSPED + 1

luc

LOCLO . BITE

LOCAT BRT?

COREETT SPECTRON3TER SETTING - SET BT CAL

TPLRIG

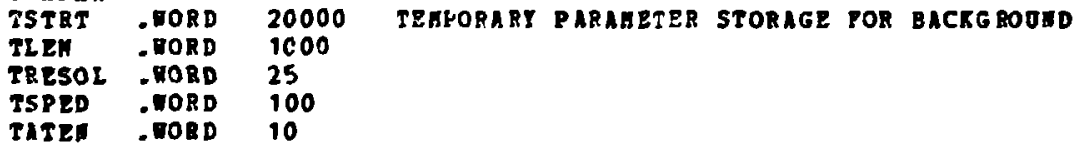

TERP

TEEPLO -BTTE O

TEEPAT BTTE

TEAPSI -BITE 0

SAVE

POA IHTPP:EDTAE RESULTS

(POR TRIPLE PRECISIOO

SAVELC .BTTE 0 SECONDRRT STORNGE

SATERT -BTTE 0

HOT.D

HOLDLC .ATE 0

HOLDAI BTTE 0

IIIDEX

INDEX1 .3TIE 0

INDEX2 -BITE 0

INDEX 3 - BITE

coont

coOnI .BITE 0

co0NT2. BIIE

coont 3 . BITE 6

OSED BI SECEOS

IDRI GDICTES

(ILE' ADDEES POINTEAS)

LOOP COONTERS 


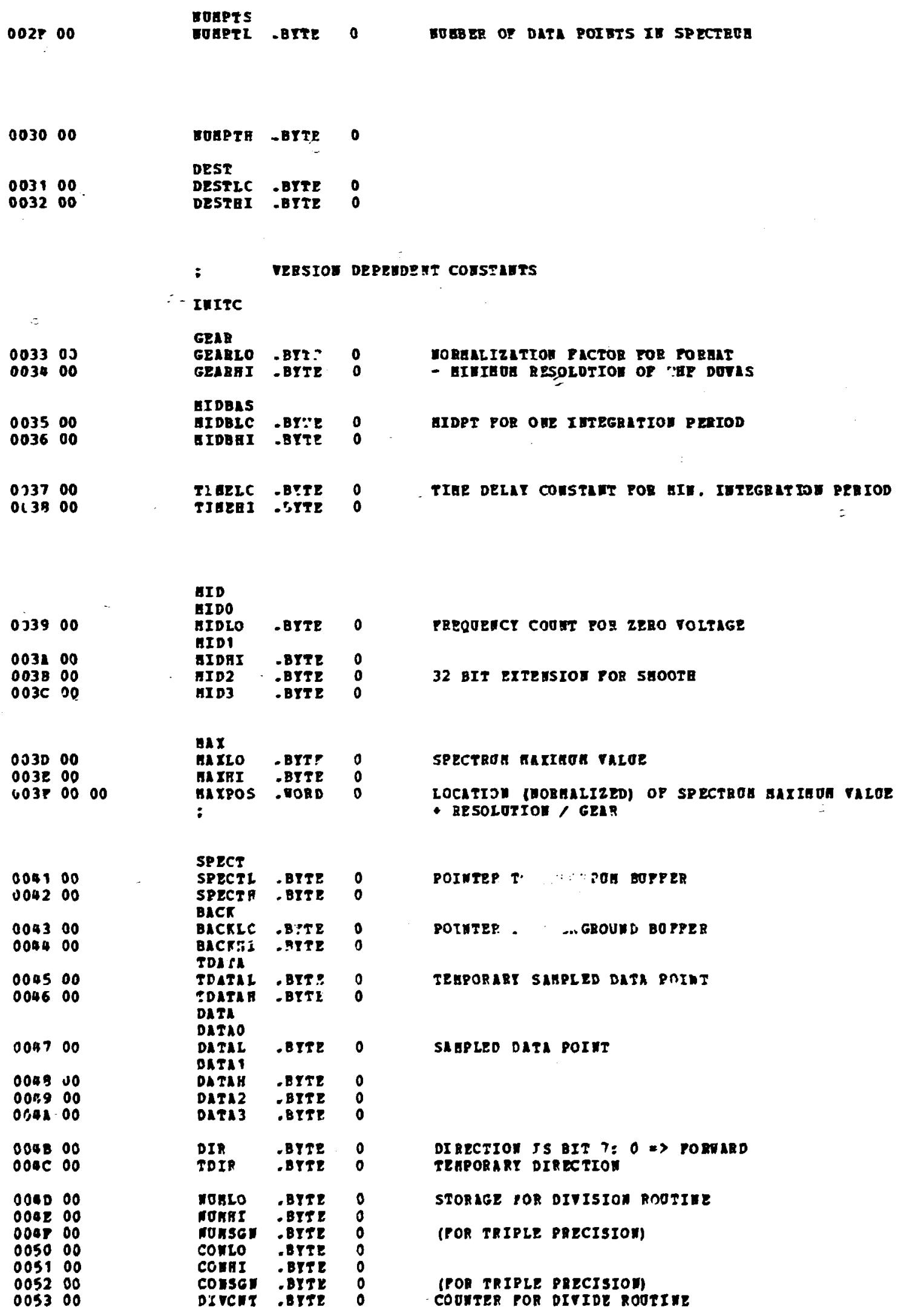




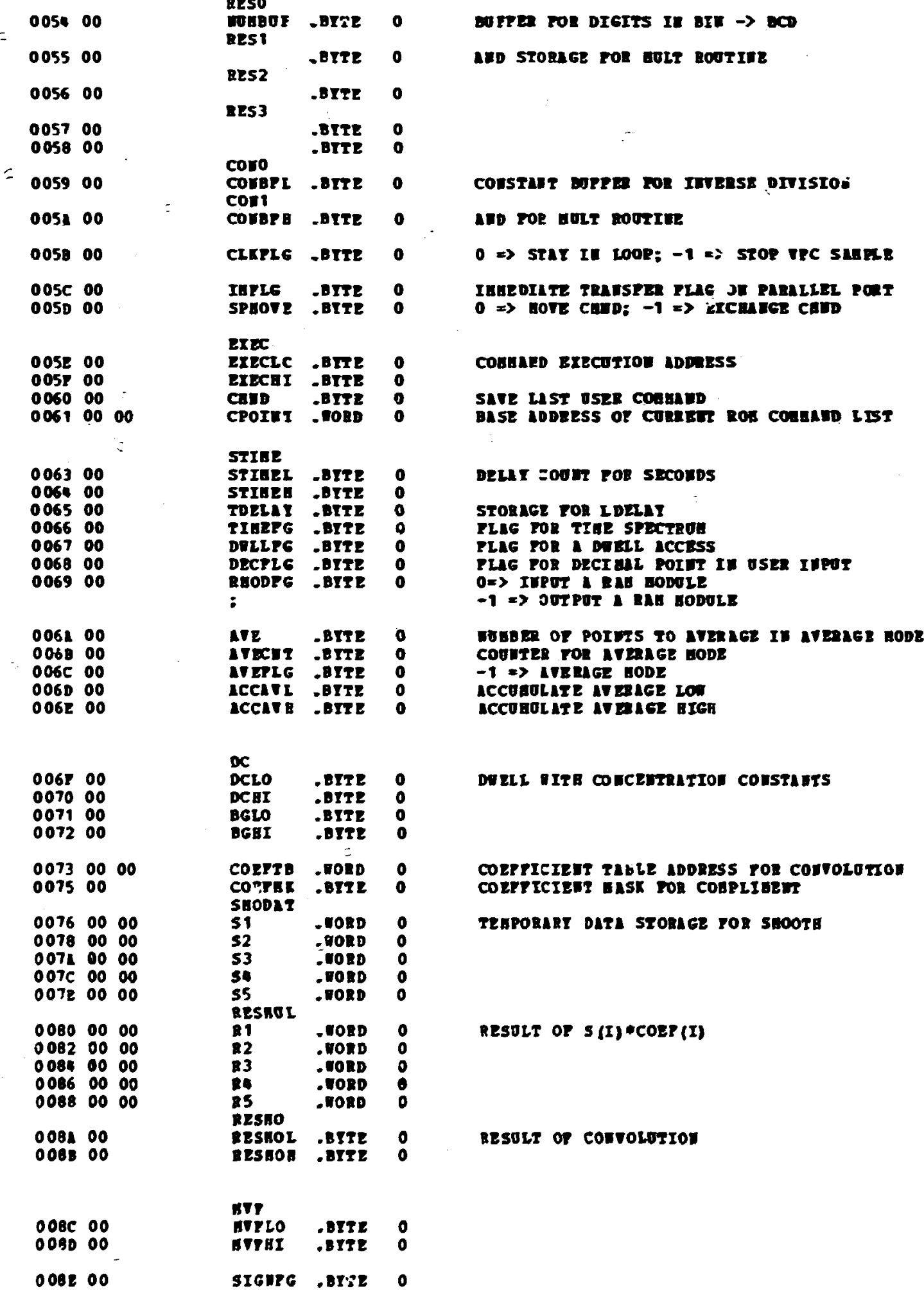




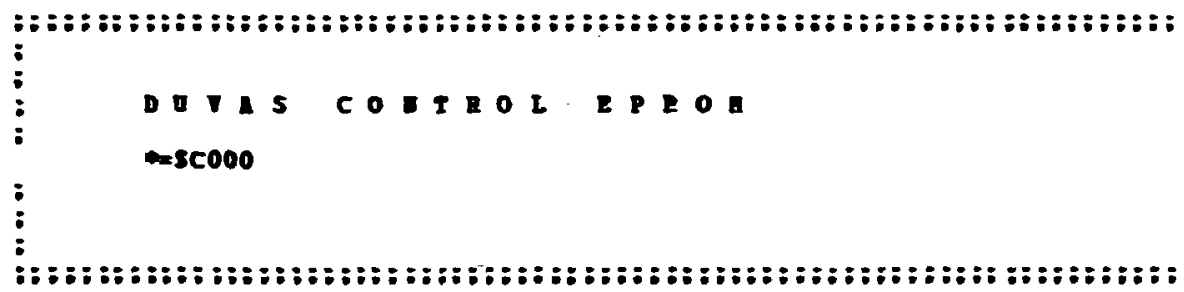

: InTTILLIE TEE STH-DOULS SI STER.

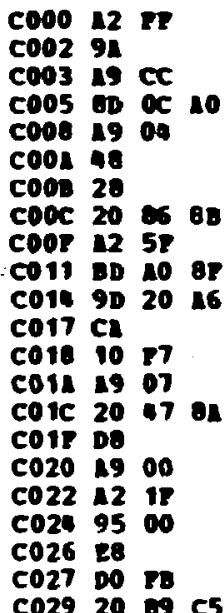

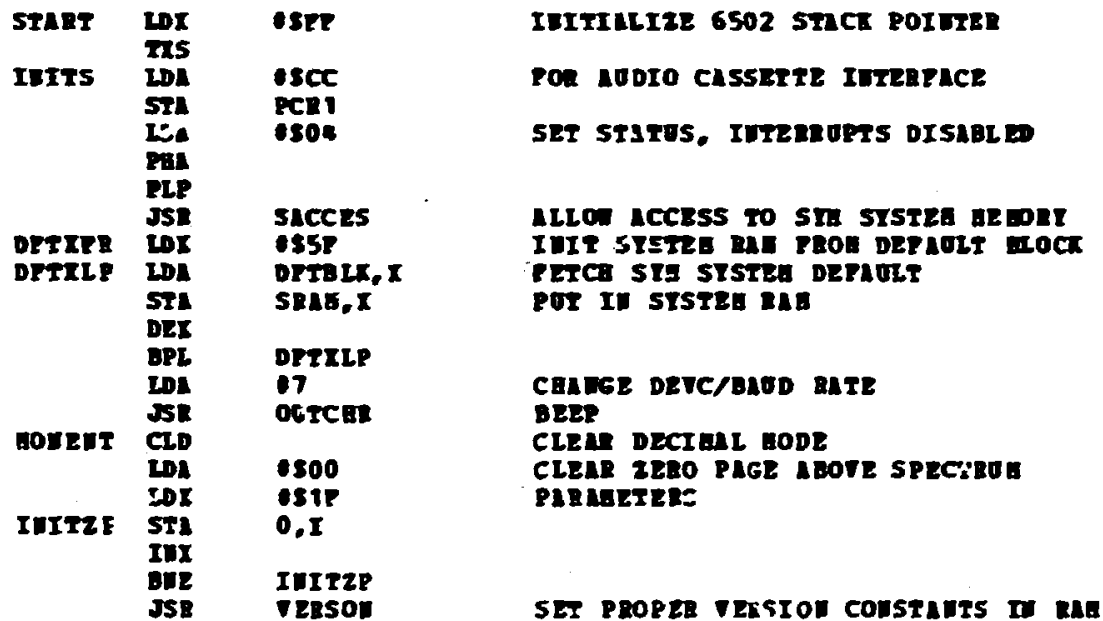

: InITIALIZE THE dUTAS I/O POETS

$\operatorname{cosc} \triangle 900$

$\mathrm{CO2E} 80 \mathrm{OB}$

$\cos 1928$

$\operatorname{cos3}$ OD $00 \quad 18$

$\cos 19 \$ 8$

C03B $8002 \wedge 8$

$\begin{array}{ll}\text { LDA } & \text { ESOO } \\ \text { STA } & \text { PITDIR } \\ \text { LOR } & \text { ES2R } \\ \text { STR } & \text { CTEL } \\ \text { LDA } & \text { ESA8 } \\ \text { STR } & \text { CTRDIR }\end{array}$

SET RORT TO IUPUT

SET CTRL LIES - GAUDSHAKE, STEP GIGG

$\begin{array}{ll}\text { LDA } & \text { Esn8 } \\ \text { STA CrROIE }\end{array}$

SET CTRL LIMES dATa dIRECTIOA

: ERECOITE PARSE rOR SYA-1 STAMD LLONE SYSTEE

C038 $20 \mathrm{oC} \mathrm{C5}$

C032 20 O5 CE

COA1 70 ID

$\cos 3 \mathrm{Cg} 2 \mathrm{~s}$

cons 5016

60478560

Co49 1200

cOA DD EP 88

cone 10 o3

coso 88

COS1 DO 78

cos3 $00298 \mathrm{C}$

co56 0980

C058 $80 \quad 0016$

cose 3021

\begin{tabular}{|c|c|}
\hline $\begin{array}{l}\text { Exzers } \\
\text { Candi }\end{array}$ & $\begin{array}{l}\text { JSA } \\
\text { JSE } \\
\text { DED } \\
\text { GHP } \\
\text { DED }\end{array}$ \\
\hline
\end{tabular}

; orsplat oser cosano

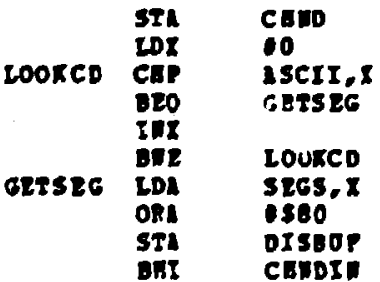

PLOAPT WITH C. CLEAR ARG

inIt rot USER ITPOT

CR - CO DO COAHAND

ARGURELT To roLlOA COAMATD?

IES, PICK IT DP ID TEA

SATE TBIS COAHAHD TOL LATEL SMRCE

1.00R rOR ASCII CODE

TOOW HACE

WEIT AsCII CODE

TRY IGIII

PICK OP CORESPONDING SEGAENT CODE

SET PERIOD rOL COEMAHD PROHPT

INSERT INTO LET CaAnCTER

(HLATS Bunce) 


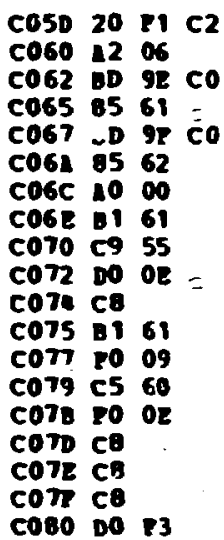

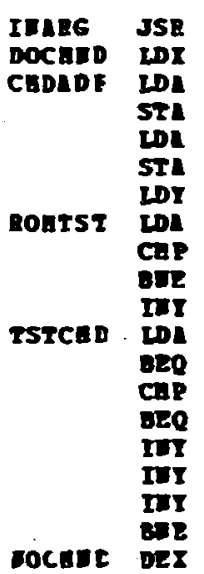

Etcap

0506

CIALE.

CPOIJT

Crablet.

CPOITI+1

1580

(Crotris).

ODOETLS

MOCEHo

(CPOIUT) I

Eochas

CaID

SETADR

TSTcad

(1)

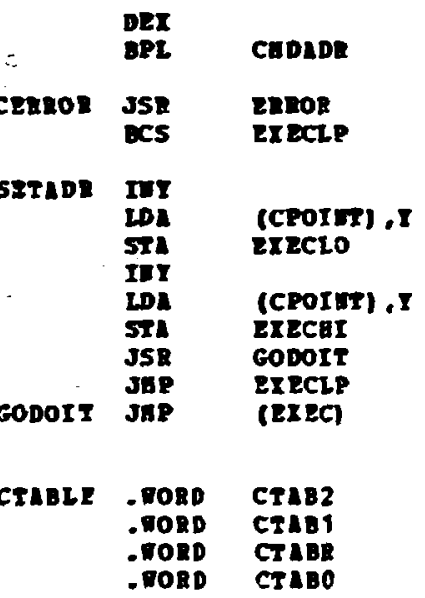

GET IEPOT RAREETER

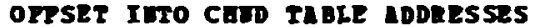

GET LOT DITE of POI HT

PUT ID coden portite

SET BI BTT OR porutet

IUDET IWTO COAHED LIST T2ST ron EITEA 809 (BEAOA)

COAEARE To PITTER of 501010101

cor PLTLER $\Rightarrow$ tos nor THERE

patzen axce. potes ro TABs.

GLF CoABND CER IEDIRECT TEE IJDEXED

DOT ID IRIS COABAD LIST

= To USER CoARALD?

IES, GL2 RovTIEe IDDESS

10. OI 20 ThE EEIT CORAR

PIUTTE COAHUD IIST

IES. POILT To lDDREss or conaind IIST

SARCE UA LIST

Esze cueaud wor Recogurzed

POIUT 20 Rourtue aDdess Lot

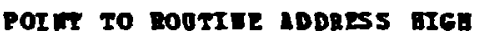

ERECUTE AI IUDIRECL JSE

PRocess TEE nLAT Coganed

a DIR ECT DRICE to Coneno notrite

EITBA ROA 2 CONHUD IIST ADDRSS

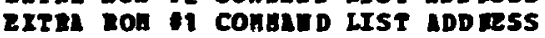
RAE COENAUD LIST ID DeESS

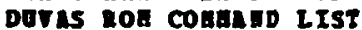




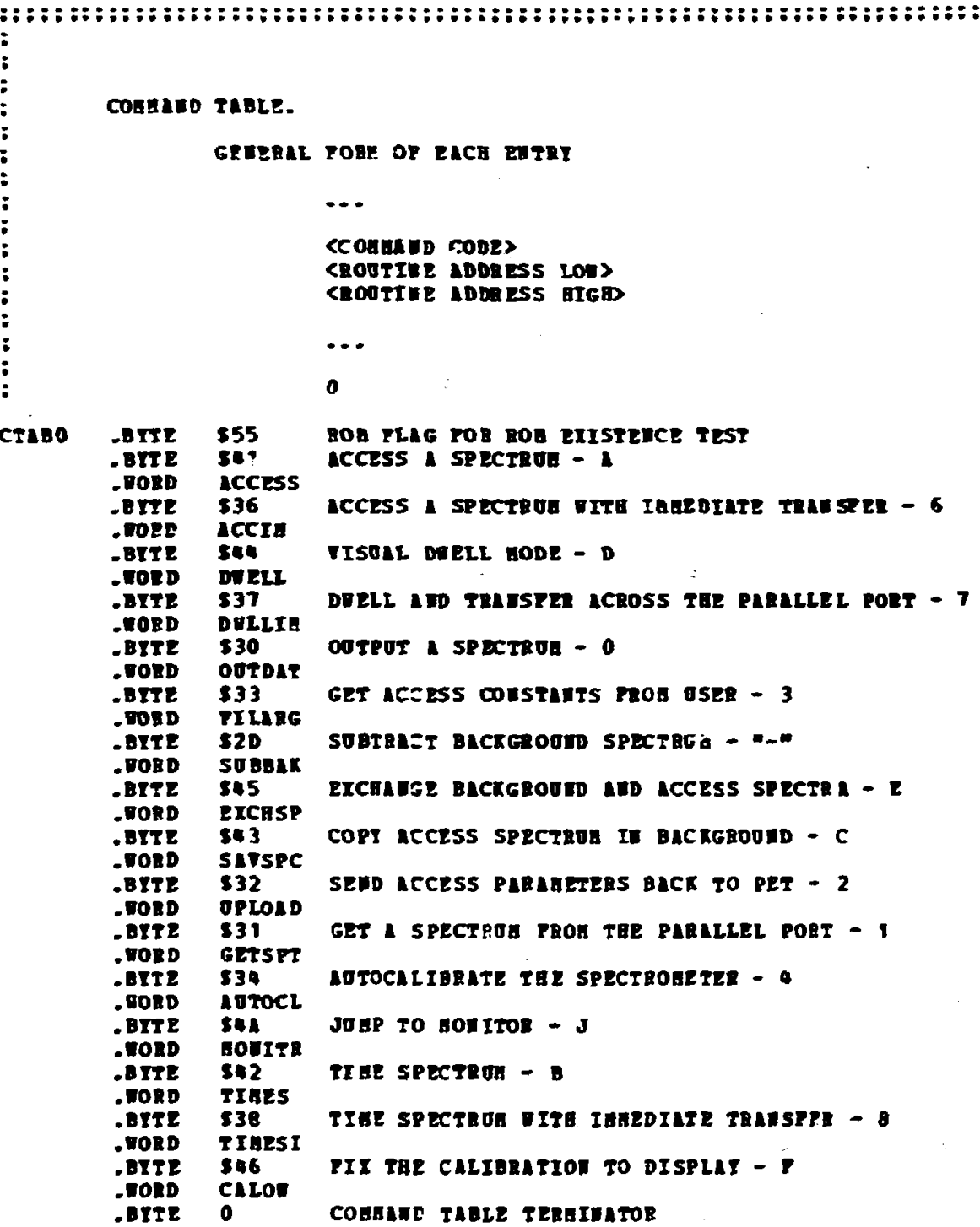




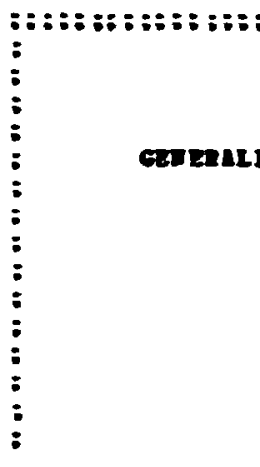

$\cos c 65 c$

Delle dec Iarke

Deu Iantore - 7.

$\cos 66 \mathrm{GT}$

$\cos 302$

Derel be purte

Dat Mccoss - D.

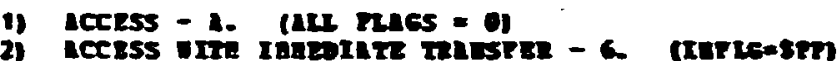

3) TISE access - 8 . (TImeros?

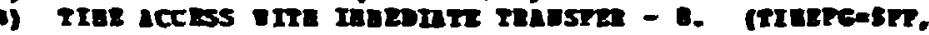
Intesto $\$$ Th

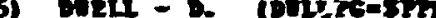

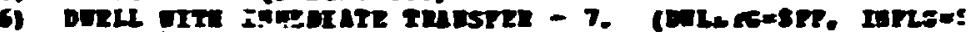

$\operatorname{cosec6}$ 5:

coto is is

Cos2 8563

$\cos 21520$

coes os 6

cose os 12

cors 0002

COEC 2653

cote C6 66

coro 30 is

$\operatorname{cop} c 6 \mathrm{sc}$

\begin{tabular}{|c|c|c|}
\hline & $\mathrm{II}$ & $19 C=2$ \\
\hline $\begin{array}{l}\text { TIuesI } \\
\text { Irats }\end{array}$ & 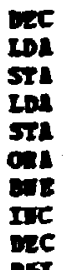 & 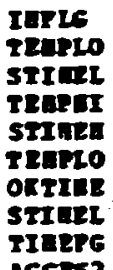 \\
\hline$\Delta C^{\prime}$ & oec & IETLE \\
\hline
\end{tabular}

Inter erinal access coer

TIOE ACCESS IAROTUTE - 0.

IIEE MCCLSS - D.

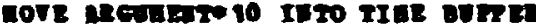

च01 $2: 207$

TES, ESE SOPTIED TITE

To, SE To DERaIT A SEC (1/10)

SE TIEE ACCES PUC

zTrE GeJal access copr

ICEIE DEC IATL

access IMALDIATE - 6 .

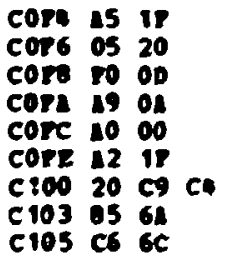

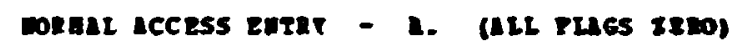

\section{ICCESS}

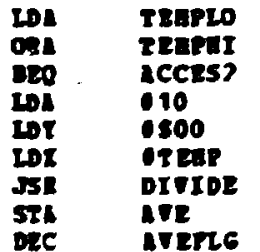

ARGTERT TOR ATELGE DOE ?

10. Monat ICCEss

T25, schis or itenlges or 10

(exi convetrion)

LI aIt or 255 rot

SET AVtRLGE BODE TLE

C 10720 18 CA

C $10220 \mathrm{Gl} \mathrm{CA}$

c 100 20 es

c110 o5 30

C 112 os 38

c114 265

c11630 02

c118 1977

Ci11 80 :0 16

c110 20 c3 c2

C120 $2071 \mathrm{c6}$

C123 1900

c125 05 (1)

C127 $10 \mathrm{TP}$

c129 20 89 $=5$

Pilase

Ponthe

CDISPE

MarLo

Baxer

OULLF

sornt

อ8?7

orspor

SETST

sexs?

$\$ \$ 00$

STI DIR

STI DIR

JSE DELAT

PILI SPECTEO paranzezs

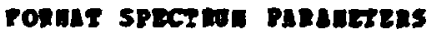

CLEN DISET, ACC STT TO EERO

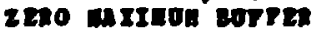

DTeLr m00 ?

TES - Do DISHAT promp

Do - SLI A. Fol LCCLSS

Instex rooks

SE snerwor pormens, mrover

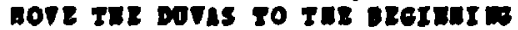

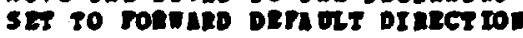

SET DIR TO ronderD

watt aboor 1/3 smodo 


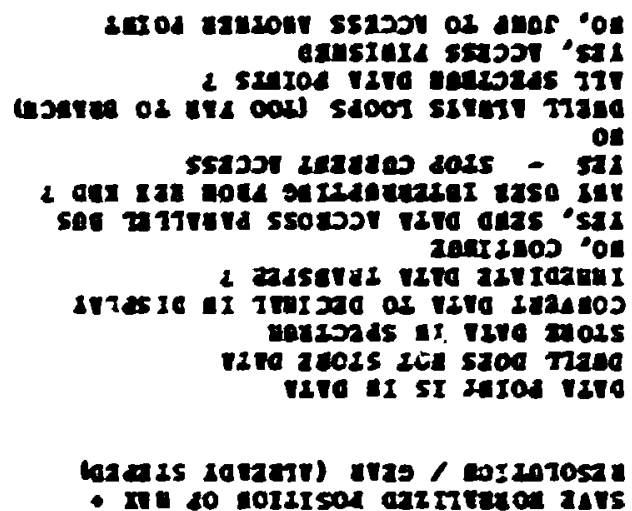

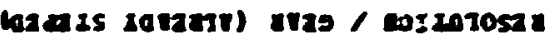

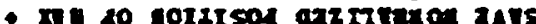

21TOd $1270+6$ ITI 21 I10

(7x) - 17a)

atrateo ine 98 isod

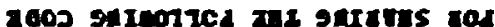

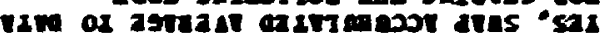
700019

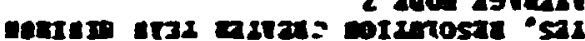

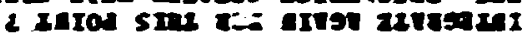
seroons es/rit is 104 stre

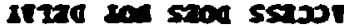
200055201 - yer ine ant ar az25

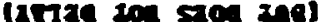
girs 100 som mane

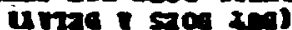
415 io 900 nevion ats 21 reari an IIs $\circ$

c zomant as senzos ne

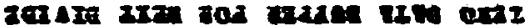

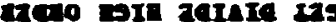

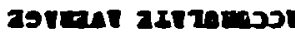

ariturua as as arm os pioa $(\operatorname{sen} 205 \operatorname{sc2})$

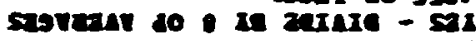

2 200 20 mant

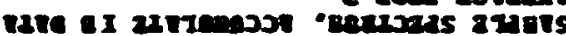

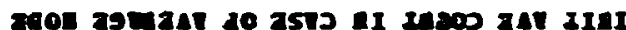
unce vive uns

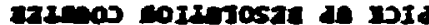

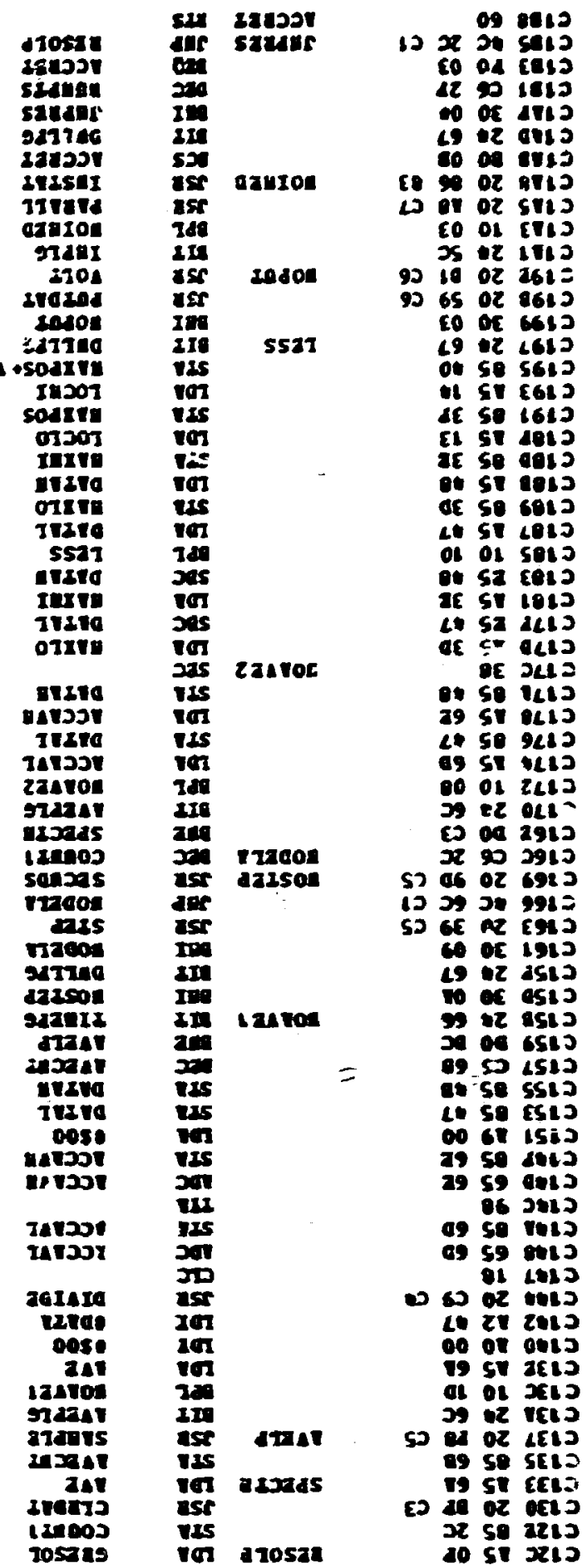


: comand:

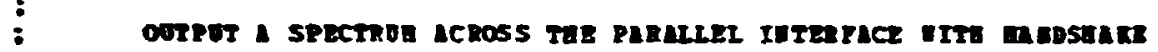

CISP 20 ad $\mathrm{C2}$

Cisc $20 \mathrm{c3}$ c2

cist $2090 \mathrm{c7}$

CIC2 20 in C2

cies c6 27

cict 00 is

C1C9 60

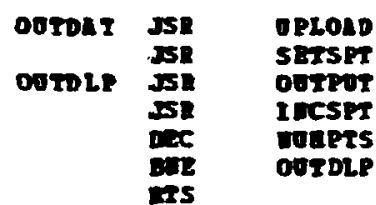

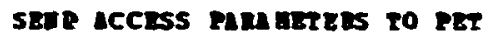

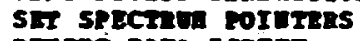

our put Bark ispect

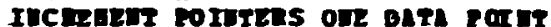

AL DATA corers?

no. Do uETT roIUt

IES. MEIT COABLUD

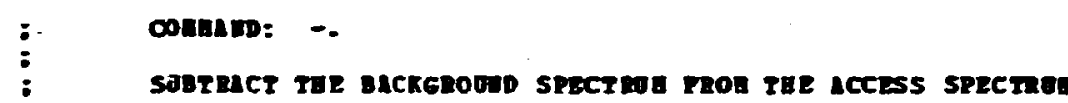

Cica $20.03 \mathrm{C2}$

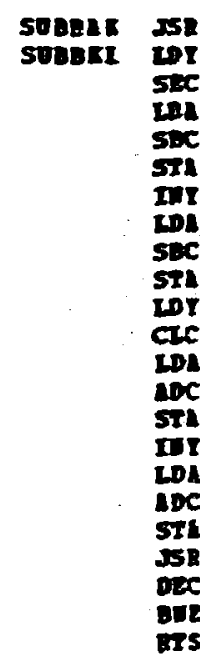

SEspt

0800

(SPecth). I

incrion is

(5exerti ot

(SPECtL) I

(Buckio),

(sFectli, 7

$\$ 800$

SE SPECTLUt poItIrES

pong specreva - encresonm

SOBTRACT LOR OLDER

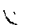

SOBTR ACT GTER OLDER

- arprorm

(SPECTL), I

GroLo

(SPECrL), 1

(SP ECTL) ,I

กIDEI

(SPECLL), I

ITespt

wants

so8ex

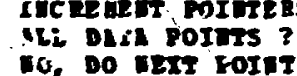

is, bo lets rorat

C1E0 Bi 1

ciza 91 औ1

CIET 81 o1

ctes 6531

CIID 20 DL CZ

c170 C6 28

C182 D0 99

Cira 60

BIS

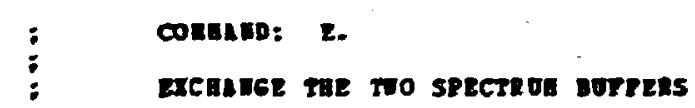

CIPS 4900

CIP7 8550

curs 20 c3 c2

cire 1000

cire $2020 \mathrm{cz}$

c261 co

$\begin{array}{llll}\mathrm{C} 202 & 20 & 20 & \mathrm{C2}\end{array}$

c20s 20 be C2

c208 C6 25

c201 0070

c2oc 12 as

c20:-5 of

c210 10
: condor zremsier / copt cope

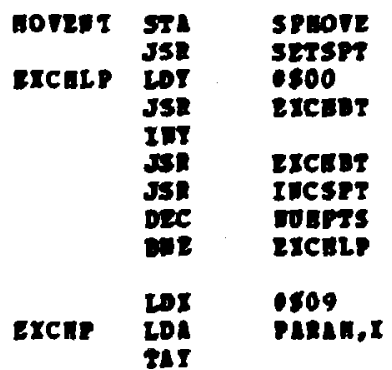

Erchs: ton

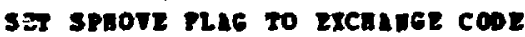

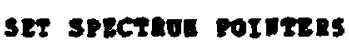

Excranom

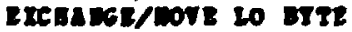

zrchnernote al orT:

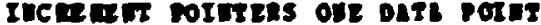

ALL DATL roters 7

no, Do pest rotnt

TES, GOTE vaMALTERS

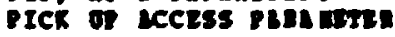

sive copt 


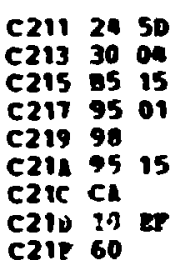

C220 $\mathrm{B} 1$ C222 $\mathrm{AL}$ C223 24 50 C225 30 o. C227 B1 13 C229 91.1

c225 al

c22 $91^{\circ}$ c222 60

C227 $19 \mathrm{TF}$ C231 $30 \mathrm{Ca}$

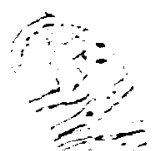

C233 20 IB CA

C236 $20 \mathrm{c3} \mathrm{C2}$

C239 20 21 C3

C23c es a7

C23E $2081 \mathrm{C3}$

C241 95

C243 2059 C6

C246 $662 T$

C240 Do ET

c24n 60

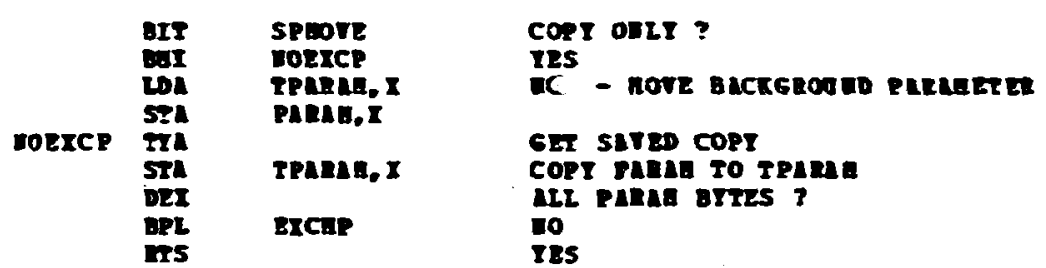

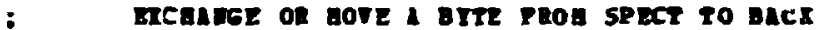

Exchat Lon (SPECTL) , I

InI SAve rol excanes

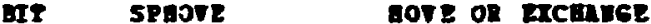

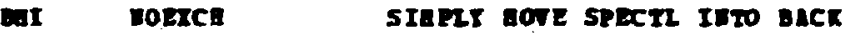

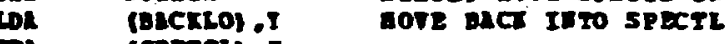

TOETCB STR (SPECTL) , T

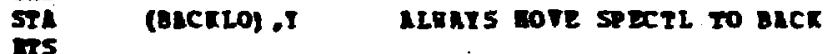

: Cosaro: $c$.

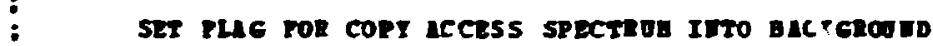

SIISPC LDI ESTR SHT TLE 50 -

BaI HOVET? JAP TO GOTE ETTEI

: Comand: 1 .

IECEITE A SPECTROG PROA TER PARLLLE DETICE

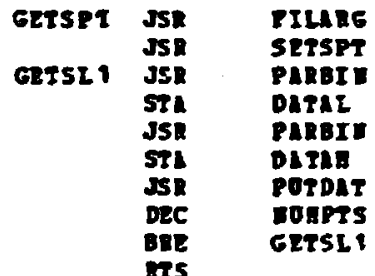

\author{
IDPUT 7RE SPECTROA PLEARTERS \\ SET SPECTRUA POINTERS \\ GET LOI BTTE ROA OSEA \\ GEF AIGA BTE MOOA OSER \\ POT DATA ITTO SPECTEU BORPE \\ AIL OP THE DATA POITIS ? \\ ๓0
}


C200 15 IF

C240 98

c242 $\triangle 2$ o9

C250 b1 드 C2

C253 9501

C255 ca

C256 $10 \mathrm{PA}$

C250 69

C259 1002

C25. 0507

C259 1533

c25P 85 os

C261 19 94

C263 os it

c26? 195

c26, is 20

cx<9 20 at c2

c2, 20 or C1

ca67 19 b4

c271 85 IP

C273 1962

c275 250

C277 $20 \quad 10 \mathrm{C2}$

C271 10

c278 $\triangle 53$

C270 2513

C27 85 35

C281 $\triangle 540$

C283 2510

c 205, 0540

C287 19 o
C289 os it

C28B 1967

C20D is 20

c2ar $20 \quad 10 \mathrm{Cl}$

c292 30

$\begin{array}{lll}C 293 \quad 45 & 13\end{array}$

C295 E5 3\%

$\begin{array}{lll}c 297 & 05 & 13\end{array}$

C299 I5 10

c 298 25 10

C290 o5 10

C29F 60

Codratbo:

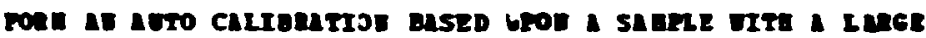

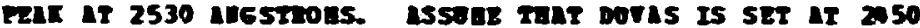
Anssrous.

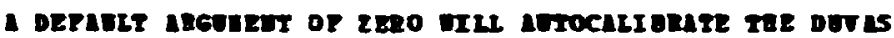

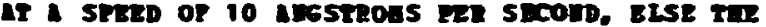

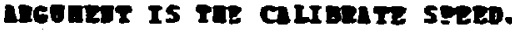

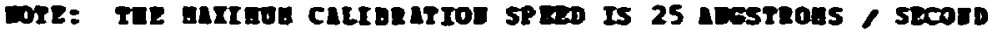

noroce

18)

T24010

SATE USA MGoters

LI

calent,

PAne.

SERP

ICDAS

STADL

GEARL

I2SOL

ALCBEet

irtero

oscoser

TEReax

CaLOE

ournec

encinz:

Temo

oncara.

TEurer

CALOT

AxPos

Locto

intogs

42ros* 1

Loct I

axpost 1

encesub

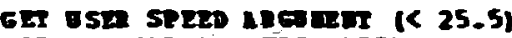

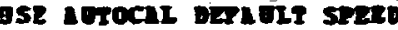

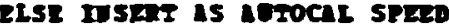

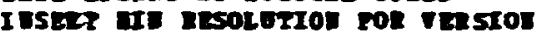

SET TUE ASSUUE IITINI ROT

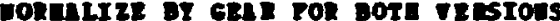

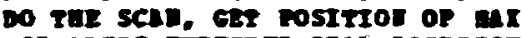

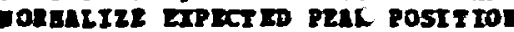

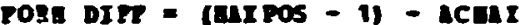

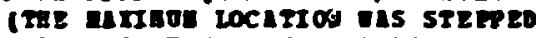

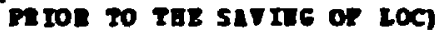

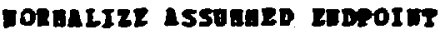

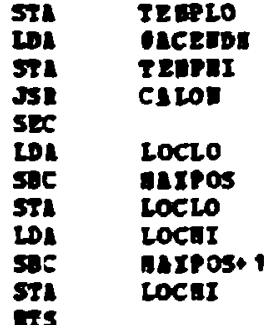

FORA LOC $=$ ACED - DIT 
C2nO $\quad 533$ C2n 1430 C210 12 IP C216 $20 \mathrm{CSC}$ c2as os 13 c2ns oc ta

caso

Pores 20 ortipen

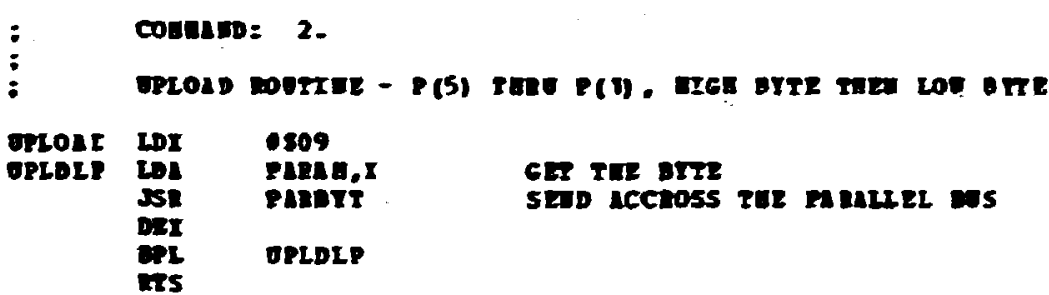

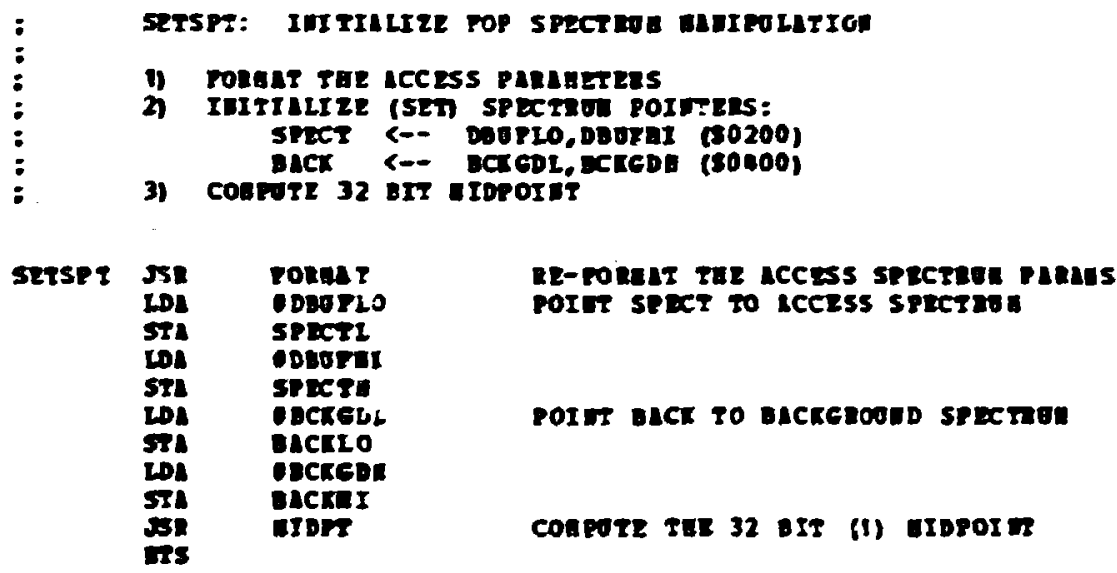

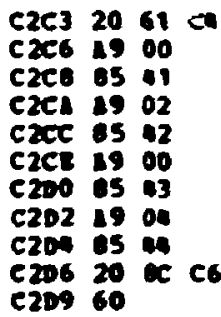

$\mathbf{C 2 0 8} \mathbf{\mathrm { L }} 09$

C24 05 of

c2uc 20 a c7

C28P Ca

vac0 10 is

e2c2 60

c2LE co 5

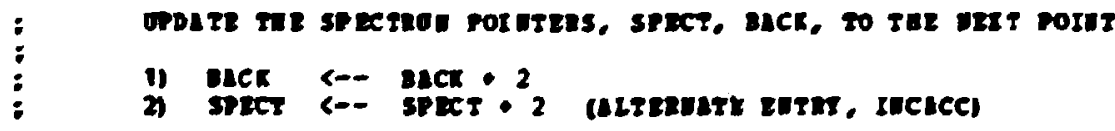

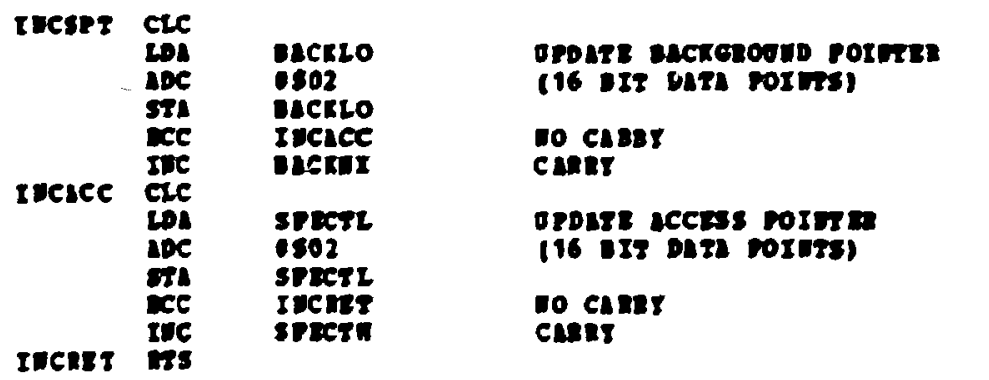

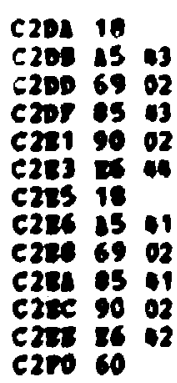
C2AD 60

cas

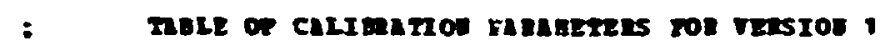

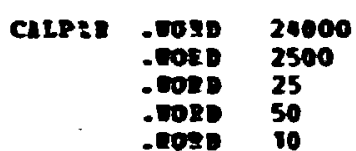

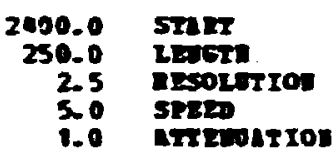
c2tos on oo

ines 10

poran we to soc of eat

Lis Oreat

ise prerp

sit uncto

DOR NITE OSE ITHT

LOCLI

swot dobinize costroo

STT

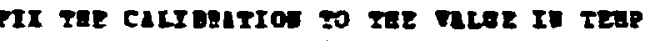

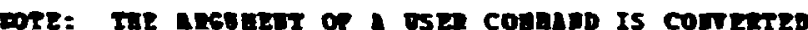
croo ch 09

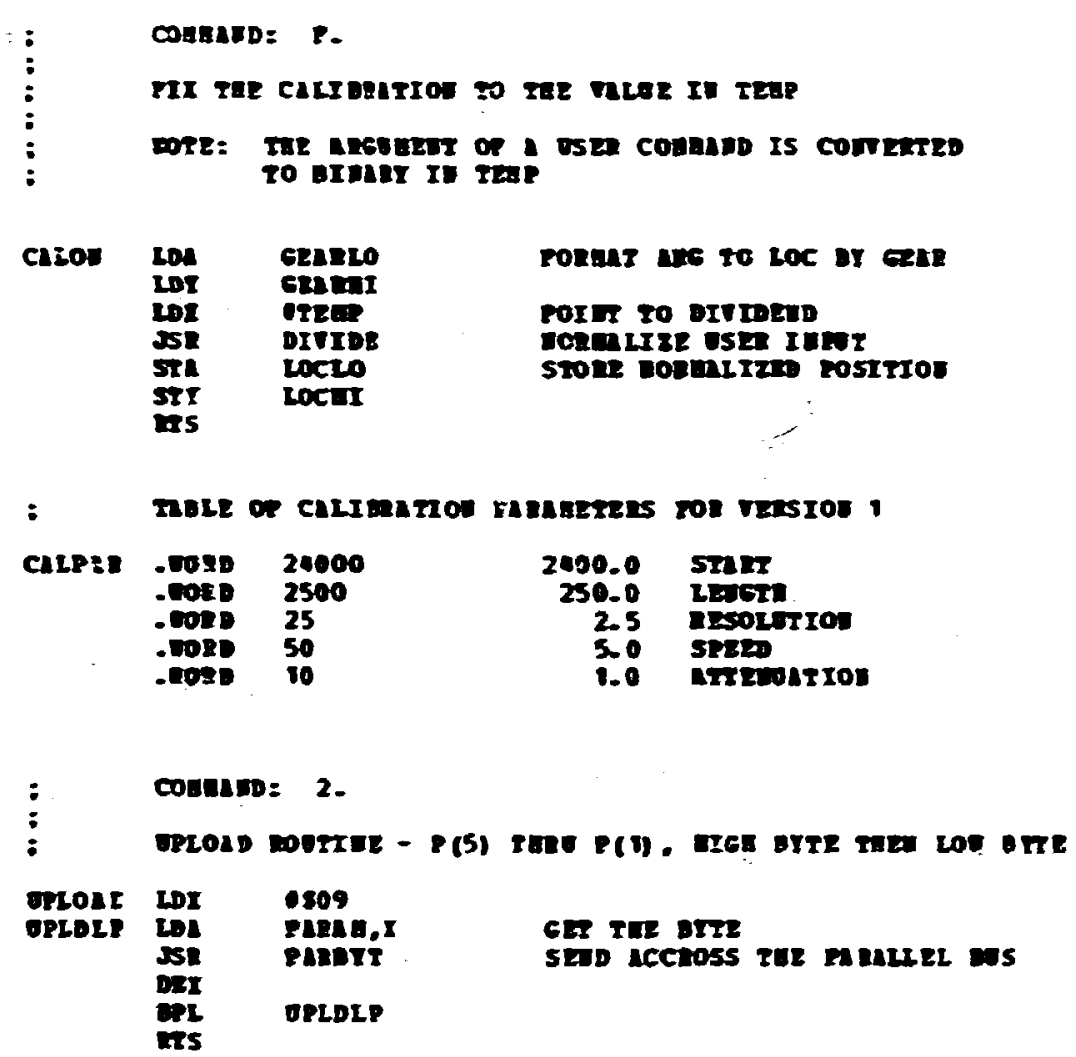




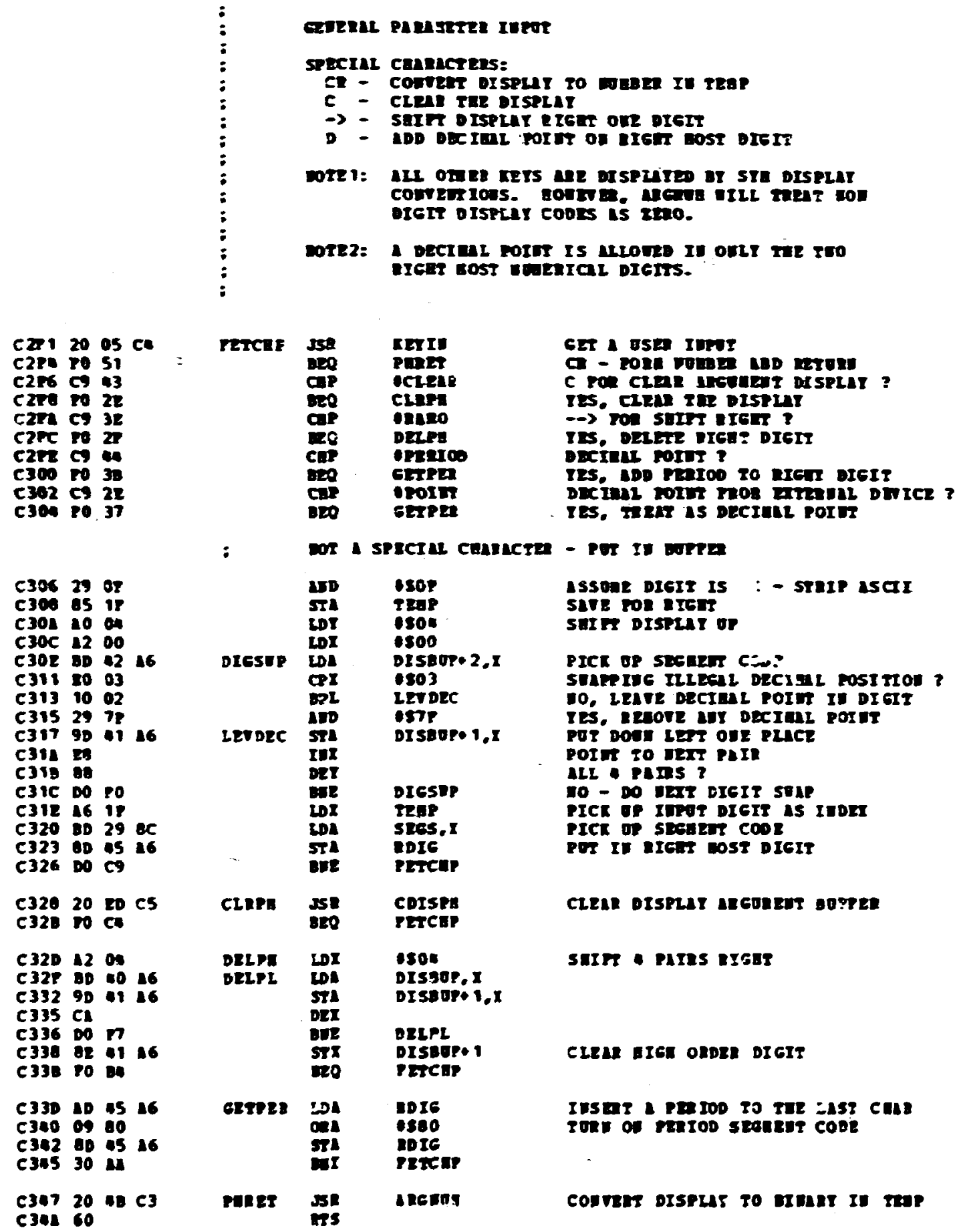




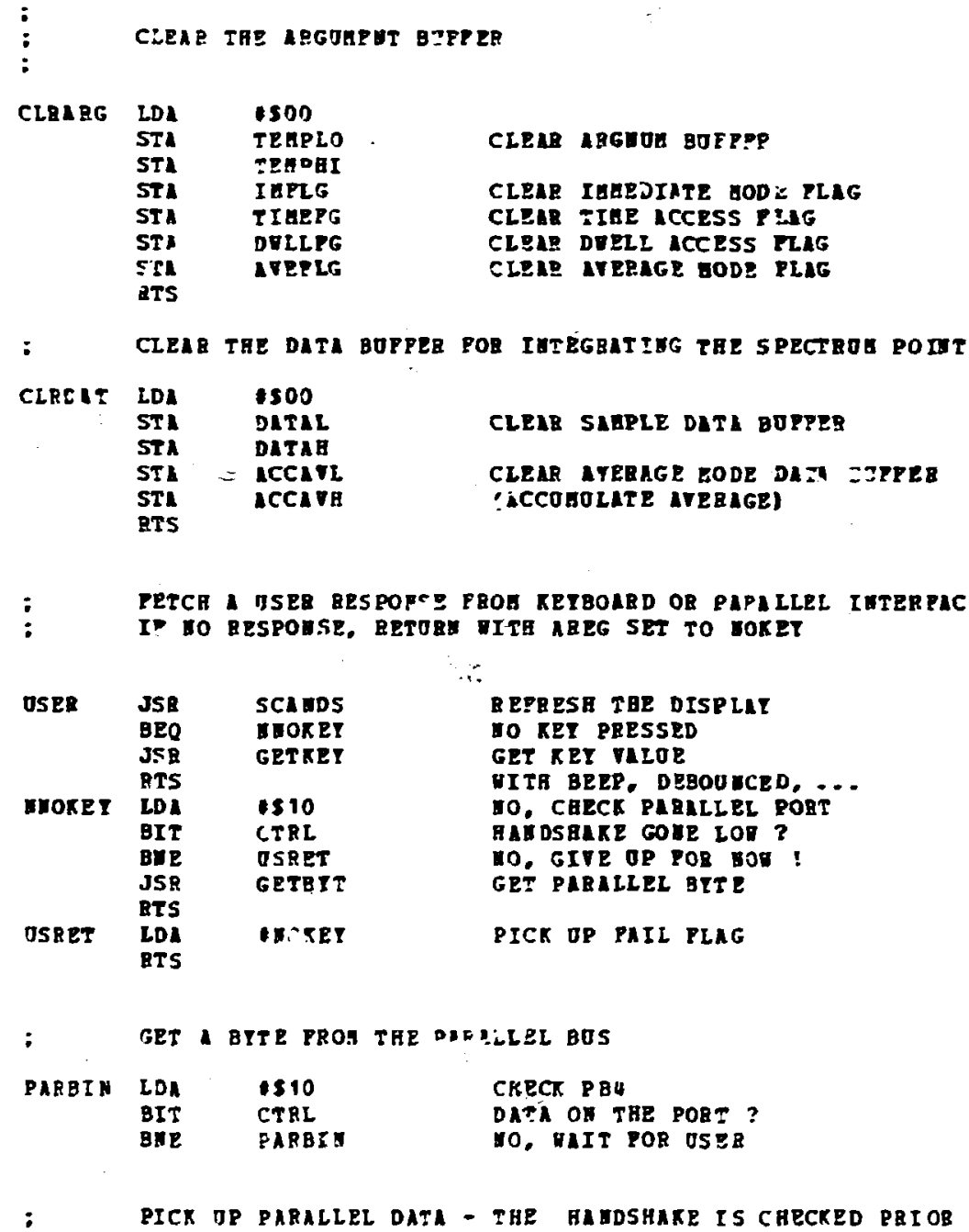

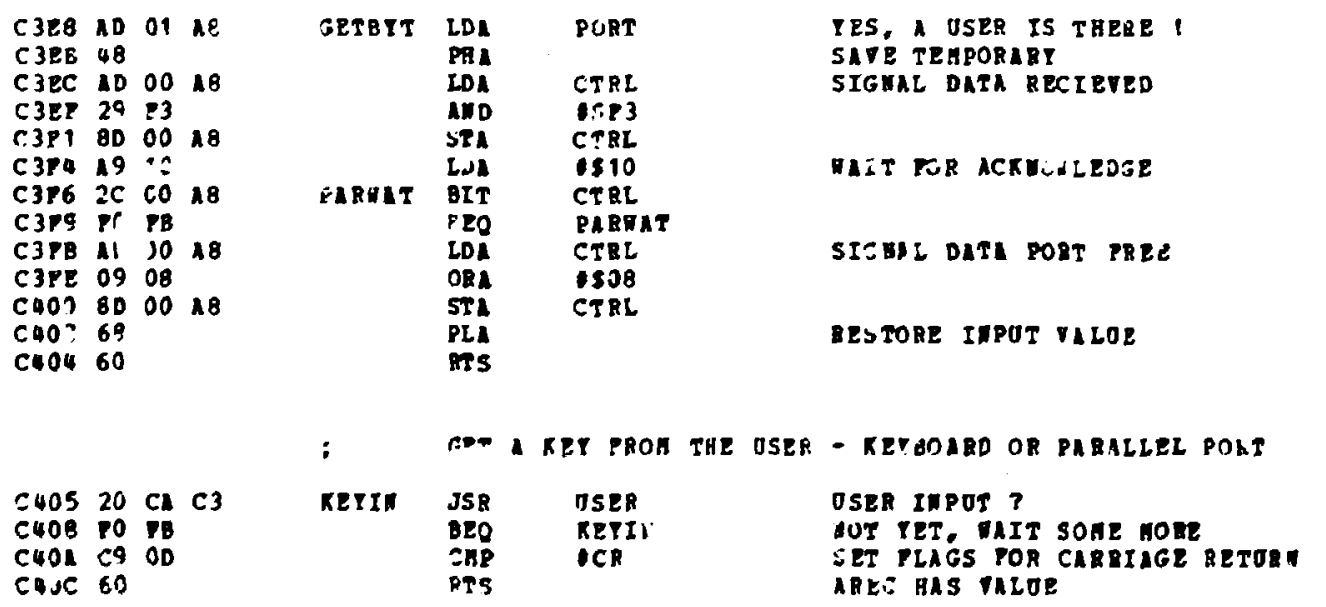


C4OD 1903

CAOP $80 \quad 40 \quad 16$

Ca12 20 \&D C5

Ca 152005 CE

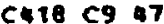

C\$11 60
Ca1B 1900

CA1D BS 21

CA1P 1901

C421 BS 23

C423 4621

C425 B5 O1

027
64 47

C4 29 B5 02

CA2B 85 (8)

C4 $20 \quad 2035 \mathrm{C7}$

Ca30 ID 16

C\$33 09 Ho

C\$35 BD $44 \quad 16$

$\operatorname{cas} 1423$

CA3L B9 29 BC

C430 0980

C43P 8D $40 \quad 16$

C442 20 P1 C2

$c 451621$
$c 457$

C447 15 18

C449 95 or

C44B 1520

CA4D 9502

C44: 2623

त451 8624

C453 2621

C455 \5 21

C457 C9 OA

C459 DO CB

C45B $2100 \mathrm{CA}$

CA5E DO $B \mathrm{~B}$

046060

BIGRT

PEOMPT THE GSER IITE ? - COAP

LDL QOEAY

STI DISBDF

JSE COISPI

JSR KEII

Cap too

ETS
ogTpat TaE prospr

CLELR REST OP THE DISPLAY

GET IIPOT KRT

RQOAL PLAG IP GO KEY

; COAGAMD: 3.

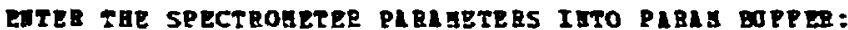

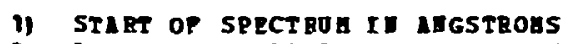

IEgGTH of SPECTPar tz A ESTBOHS

BESOLOTION OP SPECTROA IT A IGSTROAS

SPEED OF SPECT ROE II ARGSTROAS, SECOND

5) LTTEROTIOI (WOT CIREENIY OSED)

(STRT)

(LE3)

(RESOL)

(SPED)

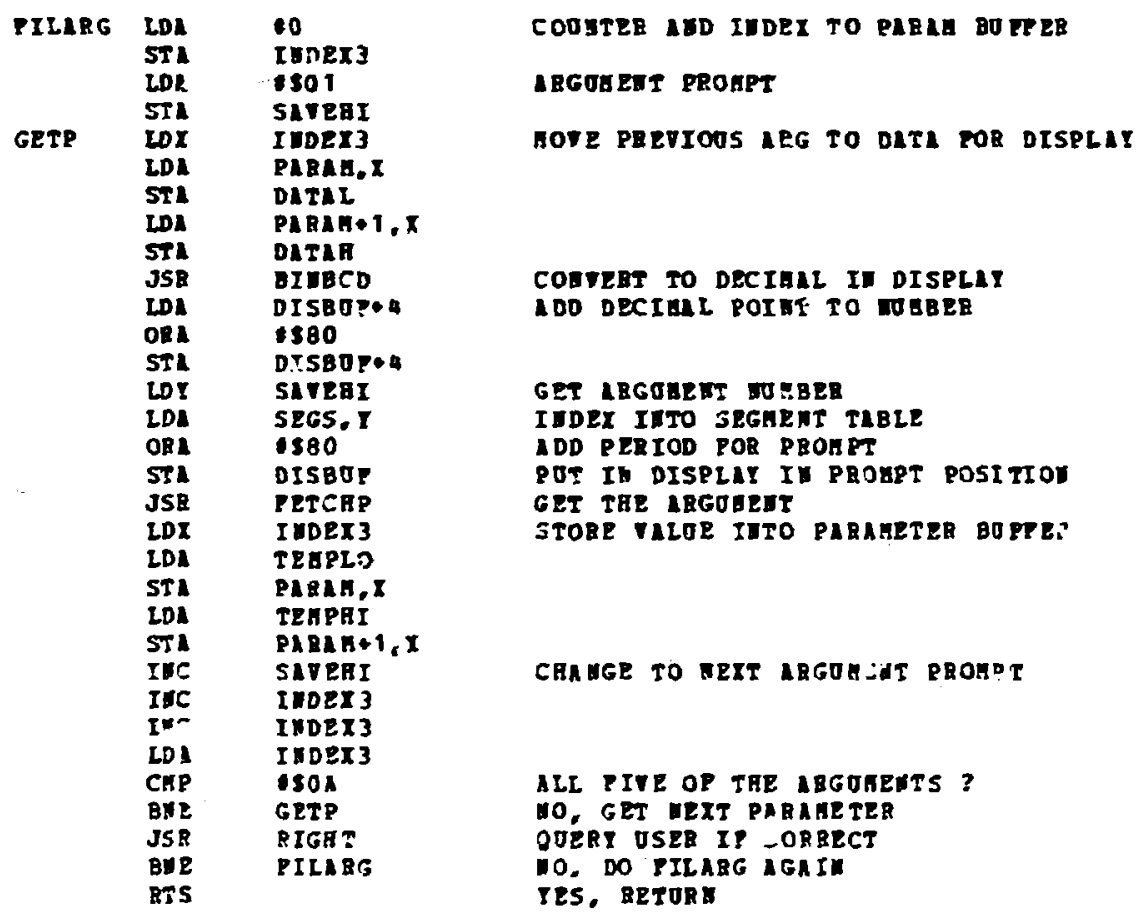

: CONTERT PARAHETERS TO TORHATED POBK IN GOPLRA BOPFER:

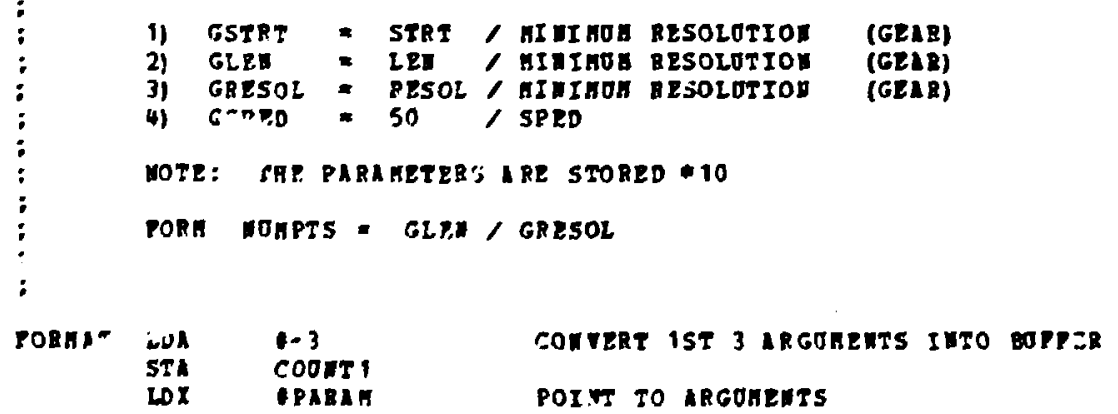

C461 1970 


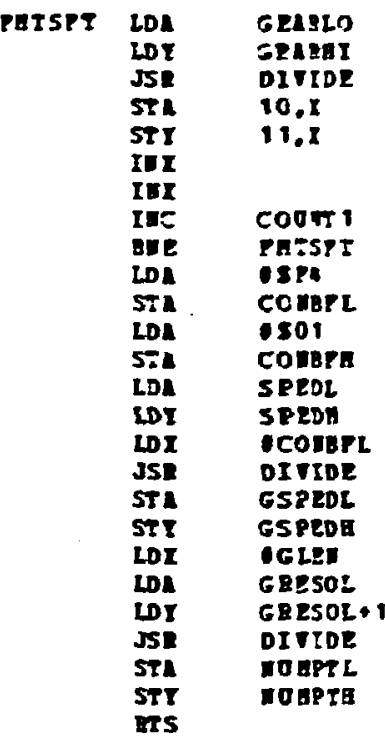

TEESIOE IIVISOE (EITHER 10 OR 25)

POREAT PABAETER

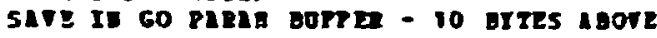

DQRP IEDEX OP

STAR, LEWGTE, EESOLUTYOH?

I25

COHPOTE 500/(SPEED 10) TO GET GSPEO

EOST OSI DITIDE ROOTIE BACKTARDS

COSTAET SET UP

DITI.OR SET OP

POINT IO DITIOESO

STORE RESOLT BACX

PORE GLEW/GEESOL - POIET TO DITIDEMD

SATE AS LOOP COUETER
CN9B 1900

C4:D $85 \quad 54$

C49P 8555

Canl 8556

C423 8557

CaLA 1559

Cant 0551

CAR PO ID

CuA? 4651

Cand 6659

CAIP 90 OC

CaBI 12 FC

CaBj 18

CAB 85 AB

C486 7558

C4B 9558

CABA ER

CABB DO 77

C4BD 06 47

C4BP $26 \quad 4 \mathrm{~A}$

EACI $26 \quad 49$

CAC3 26 4h

CACS $4 \mathrm{C}$ 15 Ca

CACB 60
:

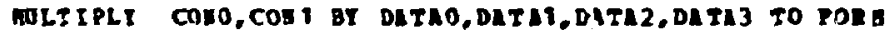

ERSO, BES1, RES2, RES3 LS 32 BIT BESOLT

COEO, CON1 IS TREATEO AS 16 BI: OUSIGEED nOABER.

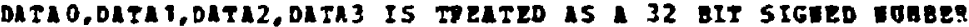

กิเT

LTR REST

RES2

$\operatorname{ces} 3$

comi

ITRRD

$\cos 1$

cono

MOADD

$-4$

1:00P

DATnOen, $x$

BEs $004, x$

BRS0.4,

ALOOP

DATAO

DATAI

DATA2

DATA3

HLOOP
CLELE RESULT BOPEE

AET DORE COHSTAET ?

Ro, IHAO DTTA NOLTIPLT

IES, PICI OP NDDMOADD BIT

IO ADDITION YOR THIS STEP

PORE PES <-- RES + DATA

Bบ:Z BI BITE

SHIPT OP DATA 


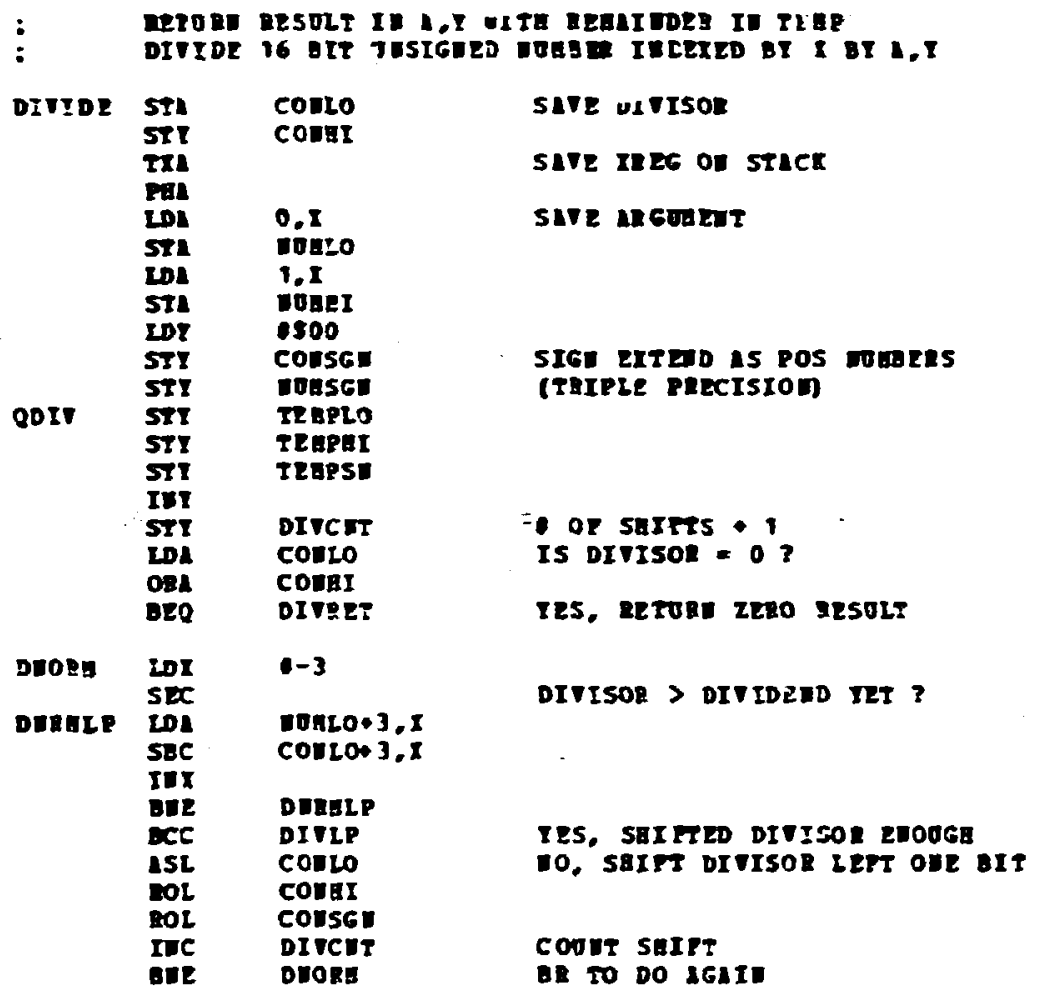

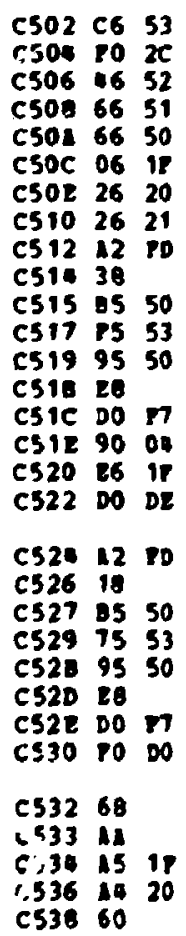

\begin{tabular}{|c|c|c|c|}
\hline \multirow{3}{*}{$\begin{array}{l}\text { DIVLP } \\
\text { DI T50E }\end{array}$} & $\begin{array}{l}\text { DEC } \\
\text { EEO } \\
251 \\
\text { DOR } \\
\text { ROR } \\
\text { LSL } \\
\text { ENL } \\
\text { EOL } \\
\text { LDR } \\
\text { SEC }\end{array}$ & $\begin{array}{l}\text { DIOCHI } \\
\text { DIVRET } \\
\text { COHSGI } \\
\text { COUHI } \\
\text { COULO } \\
\text { TEHPLO } \\
\text { TEHPRI } \\
\text { TEHPSI } \\
\text { O-3 }\end{array}$ & $\begin{array}{l}\text { ALL LOOPS? } \\
\text { IES, PICK UP IISGER } \\
\text { YO, SAINT DIVISOE IIGAT OUE }\end{array}$ \\
\hline & $\begin{array}{l}\text { LDX } \\
\text { SEC } \\
\text { 201 } \\
\text { SEC } \\
\text { STI } \\
\text { InX }\end{array}$ & 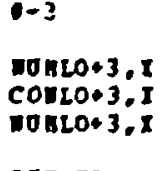 & DITIDETD C- DIVIDEHD - DITISOR \\
\hline & $\begin{array}{l}8 D=0 \\
\text { E-c } \\
\text { Inc } \\
\text { DnE }\end{array}$ & $\begin{array}{l}\text { DIVSOQ } \\
\text { TOOPIR } \\
\text { IEHPLO } \\
\text { DITLP }\end{array}$ & 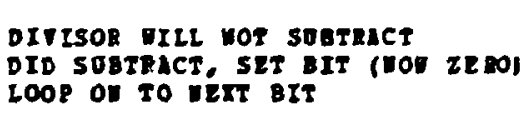 \\
\hline rooran & $\begin{array}{l}\text { Lox } \\
\text { CLC }\end{array}$ & $0-3$ & $\begin{array}{l}\text { RESTOEE DITIDEND } \\
\text { DIVIOETD }-. \text { DIVIDENO. DITISOR }\end{array}$ \\
\hline DIVADE & $\begin{array}{l}\text { LDI } \\
\text { ADC } \\
\text { STI } \\
\text { IDI } \\
\text { BNE } \\
\text { BEO }\end{array}$ & 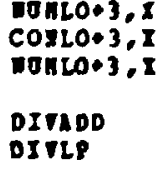 & 82 $30 \mathrm{EExT} 8 \mathrm{ST}$ \\
\hline DIVRET & $\begin{array}{l}\text { PLA } \\
2 A X \\
201 \\
2 D Y \\
x y 3\end{array}$ & $\begin{array}{l}\text { TEKPLO } \\
\text { TEQPHI }\end{array}$ & $\begin{array}{l}\text { RESTORE IREG TLOU STICK } \\
\text { PICK OP } 16 \text { EIT RESOLS }\end{array}$ \\
\hline
\end{tabular}




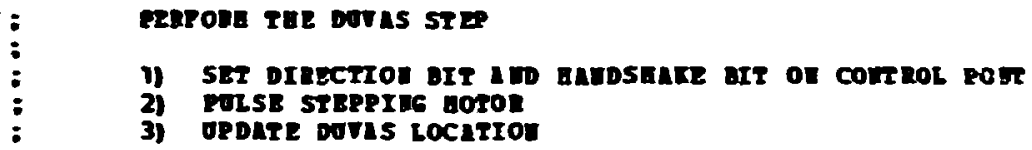

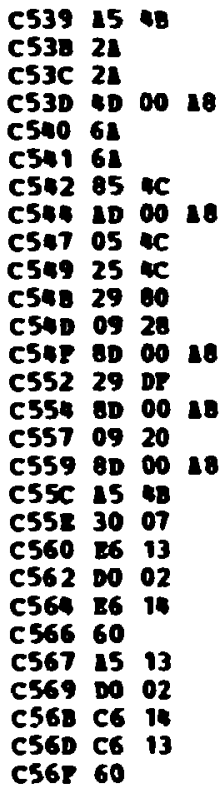

SEI DIRECIOI LOATC

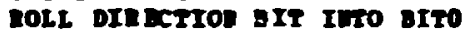

ast mra woetc gLe noLl net IUto sIG Br

SIT. THapher

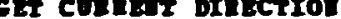

ISER VI DIRECTOU

KEEP OILI DIR BIT

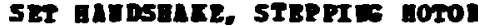

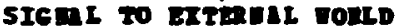

SEI STEPEIUG nOTOR EOSE LOW

Stid to boror

RESET GOMO STE RULS

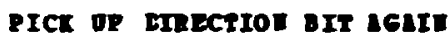

DI $=1 \Rightarrow$ DLCEIRD DIELTIO DIR $=0 \Rightarrow$ LD SIELE FOAEIOS STEP to canet

CARRT

SOBELCE DACKILD STEP

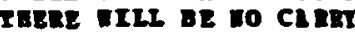

2UERE DAS a cLRET

Decteazar
:

POsit S2C

IDI

Stc

ST

LDL

S.C

SL

DII

ID)

On:

D20

IDA

POSEET eTs

: DELAT: (7. (5*256-1) *IREO *5 CICLES =

DELA IDI

DLP

DEX

Dre

DET

DEST - LOC, DIT $7 \Rightarrow$ DIR
1286 IREG + 5 cICLES

DESTLO

LOCLO

TEAPLO

DEstaI

Locar

TeneaI

Posaet

TEAPLO

TEAPRT

POSRET

6502

0

DLP

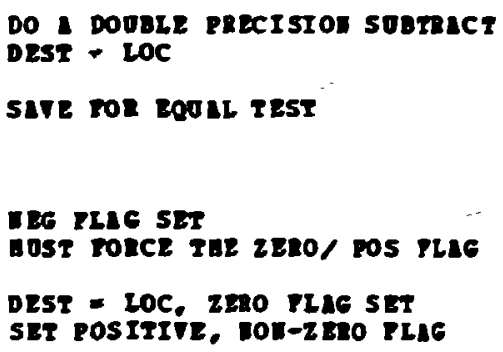

Be TIS S.Y

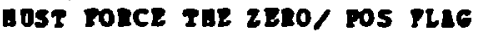

DEsT = LOC ZENO FIE SET

SET POSITIVE, DOH-ZELO TLAG

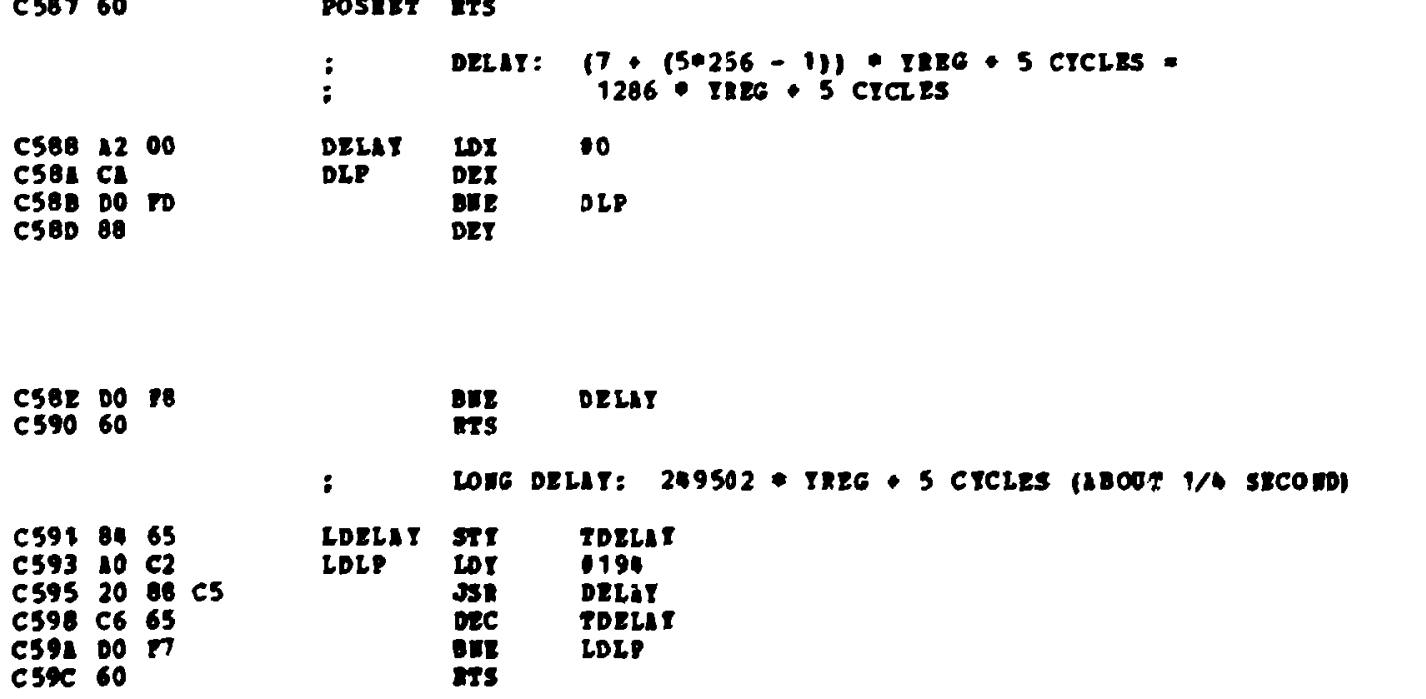




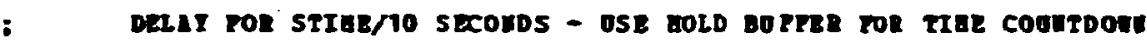

C59D $\triangle 5 \quad 43$

C592 852

CSA1 158

C5n3 8525

C515 1048

$\operatorname{csi7} 20$ ar c5

C5II 1524

csic 002

C5AB 6625

C550 C6 24

c582 1520

c5s os 25

csos bo

c5.9 69

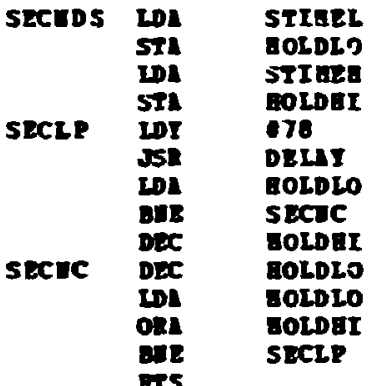

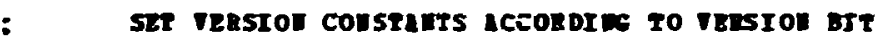

TBESOU

$\operatorname{LDx} \div \operatorname{csos}$

LI 9505

LDI 590

DI CTRI

csor 200018

$\csc 2$ bo o?

csce 10 os

csc6 89 bo c5

$\operatorname{cscs} 9533$

csed 80

csec cl

$\operatorname{cscD} 10 \%$

$\operatorname{csct} 60$

Ven2

L1

IIIEC, T

IItre, $x$

DEL TER

- rale op terstos constares

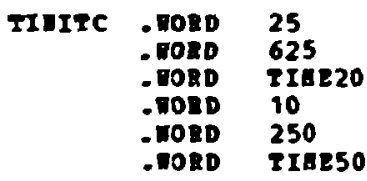

6ER - TRESTON 1 constaErs

GIDALS (POR 12500 B2)

TIBE (POR 1/20 SEC GIP)

GRE - TASIOH 2 consTIETS

GIDBAS. (FOR $12500 \mathrm{FZ}$ )

IIHE (TOR $1 / 50$ SEC GIP)

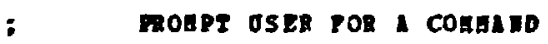

CSDC 20 ED CS

C5DF 8560

C5E1 $20 \quad 00$ c3

CS24 4989

C5E6 op $10 \quad 16$

$\begin{array}{lllll}C 529 & 20 & 72 & 89\end{array}$

C5EC 60

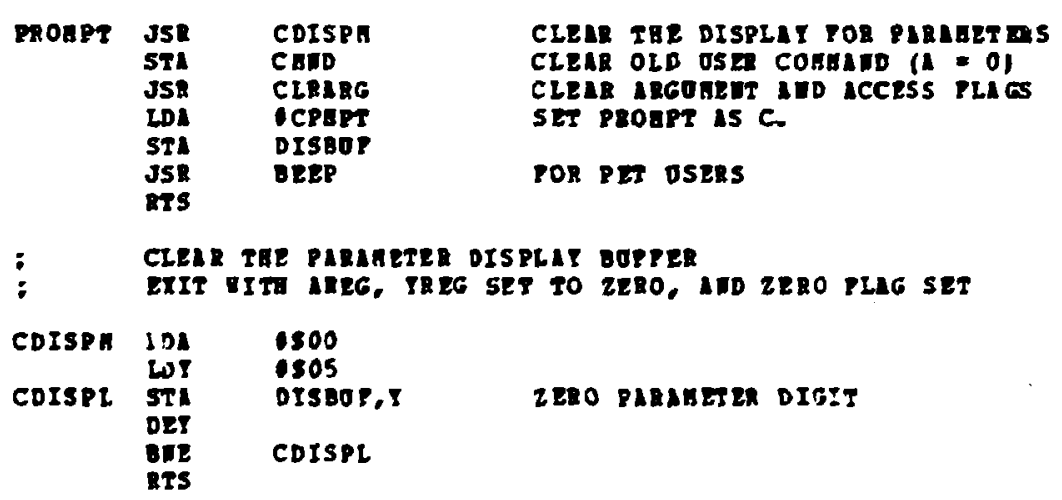


C5P8 1511

C5R 8520

C5FC 1900

C5Rz o5 58

C600 1938

$\operatorname{c602} 8072 \mathrm{A6}$

C605 $19 \mathrm{Cr}$

C607 8D $7 \mathrm{~T} 16$

c6ol 19 co

C60C 80 or 18

c60P 2920

C611 BD OS 18

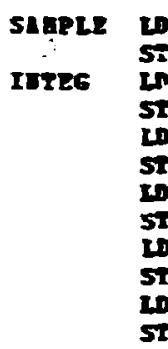

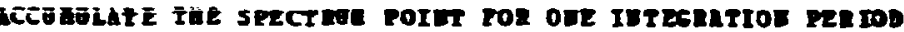

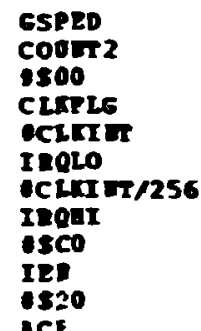

SET TEE IUTECATIOU LOOP $r$ jET

2520 1002 1215

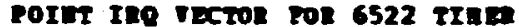

STI TmoLo

HDL CLIT Tr/256

STR IRont

IDI $\operatorname{seco}$

LDI $\$ \$ 20$

STI ICE

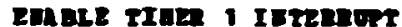

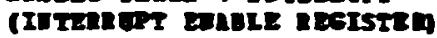

SET TIEE 2 to court IIPT poists

(aedurat corror beststed
Csis $19 \mathrm{PP}$

C6 16 oD $08 \mathrm{AB}$

C689 ob 0910

C6IC 4537

C6IE 80 OA 18

C621 $\triangle 538$

C623 ob of 18

C626 58

C627 200689

C621 2458

C62C 10 F9

C622 78

C62P C6 20

C631 02 C9

C633 60

C63. ID 0948

$\because 637$ IC OA LB

C63i Co IT

C63C DO 03

C63E 100918

C641 49 TP

C643 48

c6an 98

C645 8972

C687 18

C648 65 :7

C681 85 क7

c64c 6 B

C64D $65 \% 8$

C64P 85 .8

C651 1940

C653 9D OE 18

C656 C6 58

C658 0
C659 1000

C65B $15 \quad 97$

C650 $91 \quad 41$

C65: C8

C660 $15 \quad 48$

C662 91 if

C664 20 I5 C2

C667 60

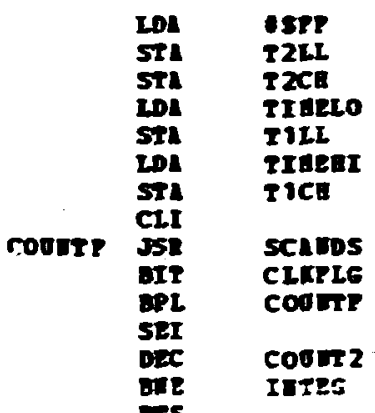

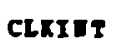

Don

cle

IDC

STI

PLA

IDC

STI

LOD

STh

D2C

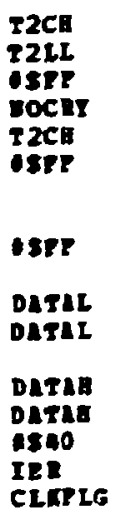

Set TIMER 2 To aAx coort

(TIaLA 2 LATCE LOA

(ITAER 2 cowt a [6I)

SET BLSIC TIMEOUT I UTLATAL

(TIMER I LATCE LOT)

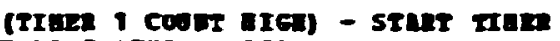

etrae rial ntrenort

Desplat last couvt

Tre r raned ov? ?

80, cover bo2E TFC roLses

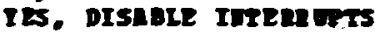

III TIDE IPDEGReTIOIS ?

I0, $\cos T$

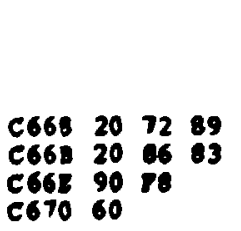

;

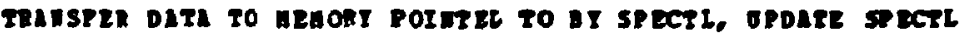

\begin{tabular}{|c|c|c|c|}
\hline POTDAT & $\begin{array}{l}\text { LDI } \\
\text { LDI } \\
\text { STI } \\
\text { ISI } \\
\text { LDI } \\
\text { ST2 } \\
\text { JSR } \\
\text { LTS }\end{array}$ & $\begin{array}{l}\text { lo } \\
\text { DATAL } \\
\text { (SPECTL), I } \\
\text { DAgAB } \\
\text { (SPECTL) I } \\
\text { ImCACC }\end{array}$ & $\begin{array}{l}\text { Por } \\
\text { Lon } \\
\text { IIX: }\end{array}$ \\
\hline$\vdots$ & $\begin{array}{l}\text { DePeP } \\
\text { ExIT }\end{array}$ & $\begin{array}{l}\text { ONITS. A iEI IS } \\
\text { DITA cIRTI SET }\end{array}$ & PRess LD \\
\hline ER20R & $\begin{array}{l}\text { JSR } \\
\text { JsR } \\
\text { scc } \\
\text { ars }\end{array}$ & $\begin{array}{l}\text { EEEP } \\
\text { Iustat } \\
\text { ERLOR }\end{array}$ & \\
\hline
\end{tabular}

CopI IIEA $\cos \pi$

possinze caner ?

so

TES. GET UET (ATD POS. DIPTER ETS ETCE

PON: ORES COAPLIERTT

SAVE TETP

GET LOT OADER

ron: otes Comlinert

IDD 20 DITI

RESTOEL GIGR ORDER

20R: ORT TIAER ITTEROTT OUTIL RESET

SET PLAG TO BRER LOOP

OR 6502 IUDIEECT

DN BTE

I BTTE

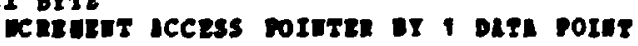




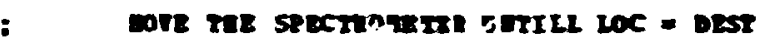

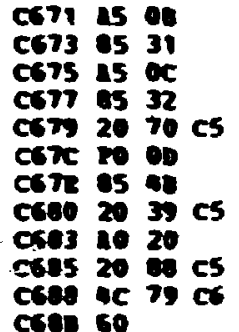

cote is 10 cose os 39 CS90 o5 31 Cs92 is 30 crsh os $3 \mathrm{C}$ c5es as it cose at of cose te

CSe 15 39 c50 6535

crer es 39

CGI 1531

$\cos 36536$

Csas 85 31

C617 8

Csie do 70

csa ca

C640 Do

cha 19 o0

con es of

c6er 19 a

c6e3 as

cons 19 is

C6et as

C6es is 39

c6De es 50

cred 1534

c6er o5 51

cect 1000

cses o4 52

coCs 20 co C6

cces 85 oc

crca on 80

csec 60

cceo 48

CSCE AC DO C"

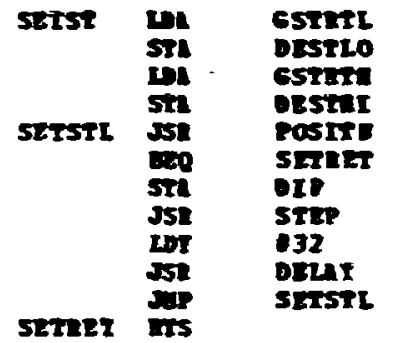

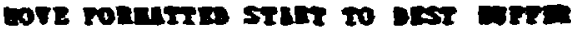

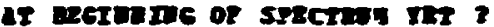

1Es, newar

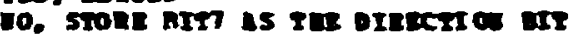

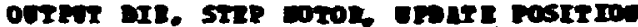

DELT IOS netrito

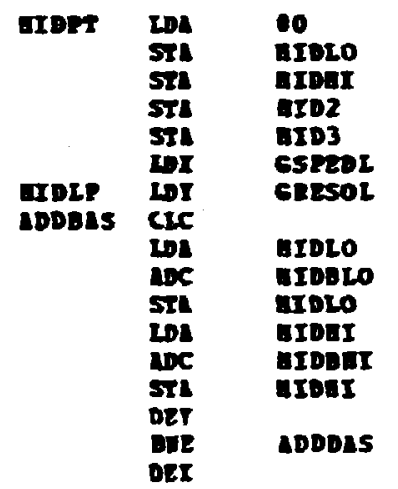

8200 conner mpotas

(32 orrs)

pol EMCE SPED I rrentrou

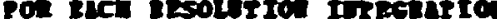

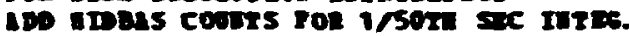

ADP 100 (IIIDas, 250)

ADD IUT (EIDELS/256)

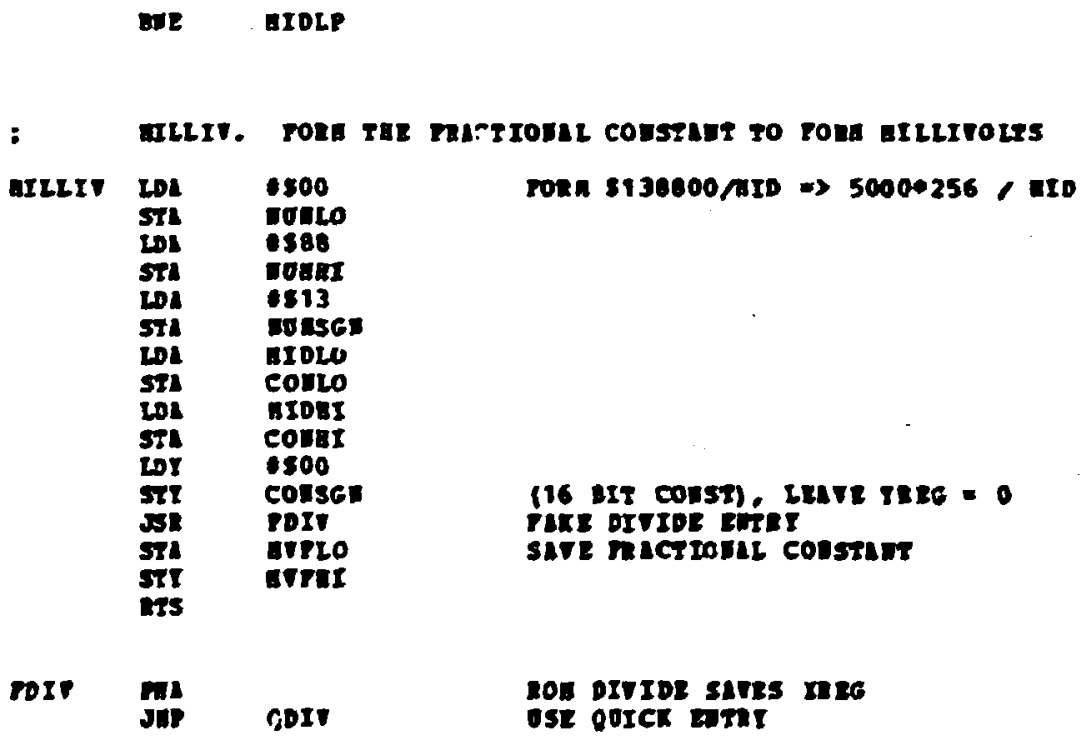




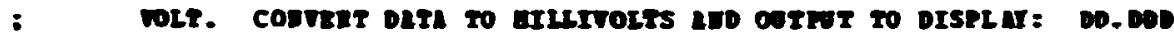

Cos 1900 $\cos 3$ os of $\cos 38$

cser 45 at $\cos$ is 32 cose 55

c6re as of

cons 35

csw os ar

cor 00 is

C6I4 1940

coses os as

c6x 15 \& 4

$\cos 49$ It

cone 38

CST 0900

cst 85 a

cort 154

cors is ip

cors 69 00

C6m os 4

cos is c

corr os 59

Corp is iv

core os 5

C701 19 a

c703 os 4

c70s as

C707 $2098 \mathrm{CO}$

c70 1555

c7oc as at

c705 $15 \mathrm{SE}$

c710 85 4

c712 45 ar

C714 oD $40 \quad 16$

C717 $2035 \mathrm{CT}$

c7II 10

C7IC AD 16

c7ir bo oj

c721 ce 16

c724 $10 \quad 43 \quad 16$

c727 00 03

c729 u $43 \quad 16$

c7x $10 \quad 2 \quad 16$

c722 090

c731 804246

c734 60
VOLI

Ind 050

sil SIGITE

DL DITLI

sec paro

SIL DITI

in Dera

Iinit

D21:

Totrsi postrits ato

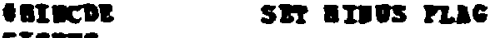

stente

Detr

OSFT

6500

Dext

DARL:

CST

ssoo

DIm.

BVTLO

cono

aTPL

COII

0500

DISL2

Dมrล 3

avt

RES1

D)ra2

Desz

D)

SIENPG

DIseor

OIIBCD

- 537

DIseare

IOELEI

DISEvete

BIsedre 3

E0DLx 2

DISEOR 3

DISE0 $P \bullet 2$

$0 \$ 80$

rona 16 bIT 2 's cotruthey

is coptingt

$\rightarrow 1$

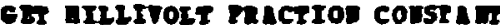

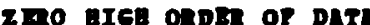

PMCTIOTLL Gutript

SCALE BI 256

POI SIGI In DISPLAT

place data in displat

PORAIT POR DD.DDD

ADo Dereal portr
ASSOME ROSITIVE DAR
C735 $\triangle 5 \quad 47$

c737 85 is

C739 1540

c738 o5 96

c731 1900

c737 0526

c741 0520

C783 19 os

c745 o5 26

c747 1426

C799 $8993 \mathrm{ct}$

c7uc os

c78p 19 of $\mathrm{ct}$

c750 18

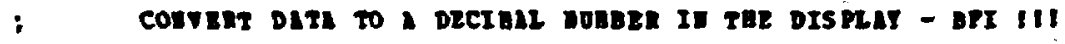

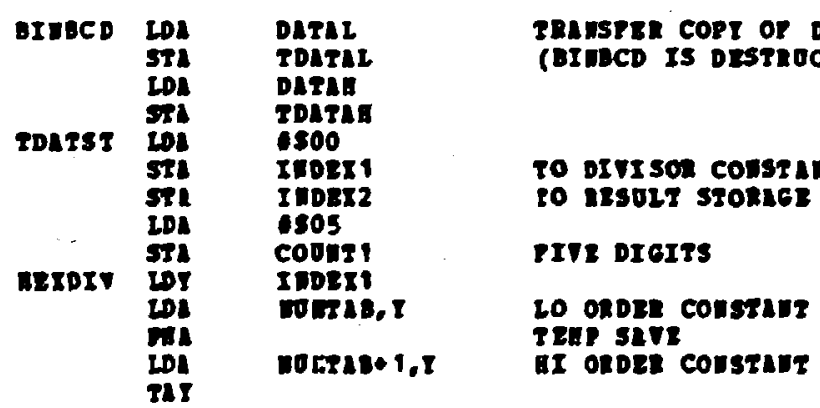




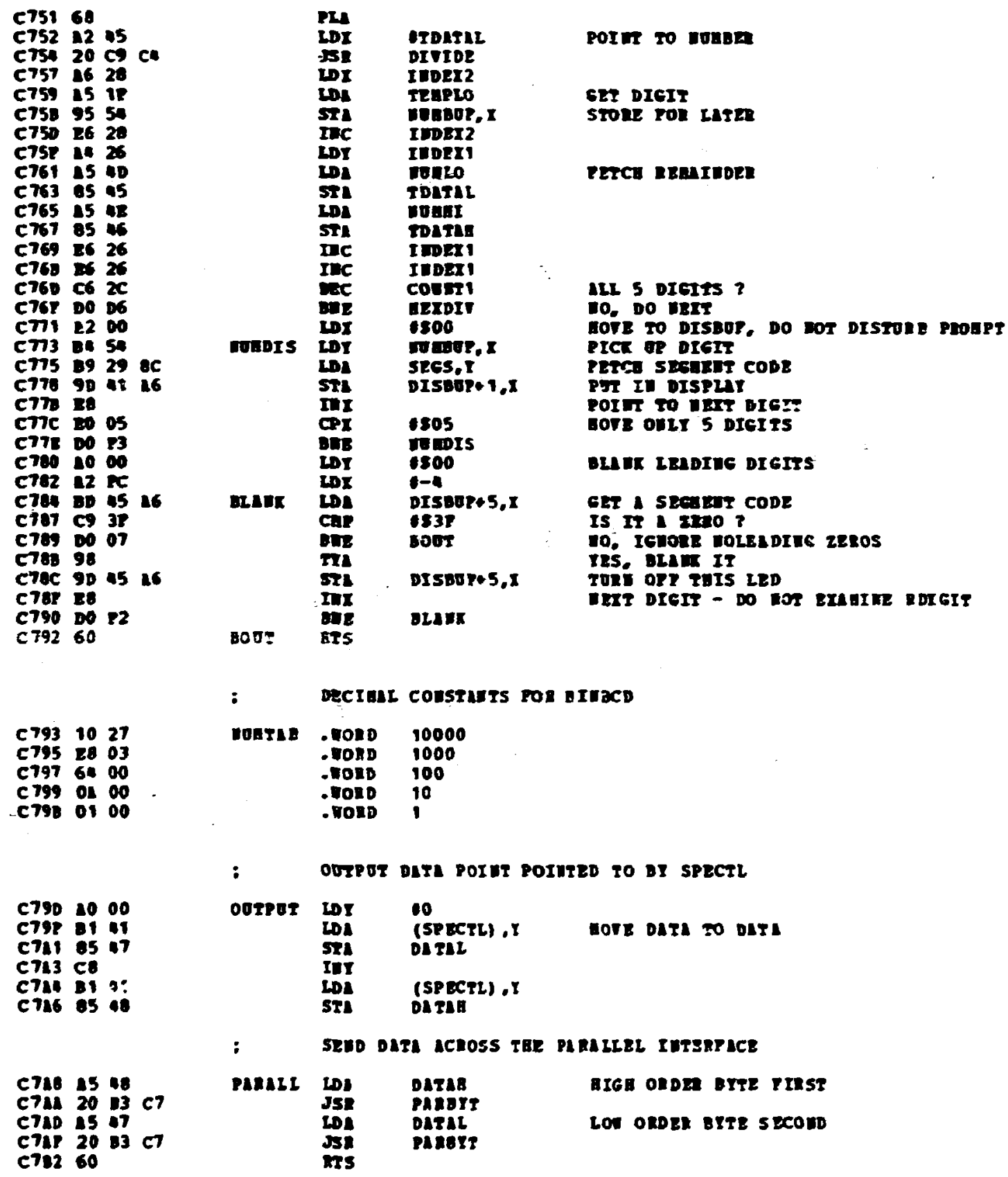


C7e3 000118

c7es a9 ip

cree 80 os 18

c7es 19 10

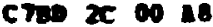

cree bo 1

cre2 19 I7

C7es 200018

c7CT be $00 \mathrm{A0}$

cree 1910

cree 250018

C7CF 10 It

c7m 196

C703 00 00 a

cres 0800

c.79 1900

C7D 80 os 1

c7as 60

:

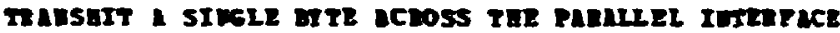

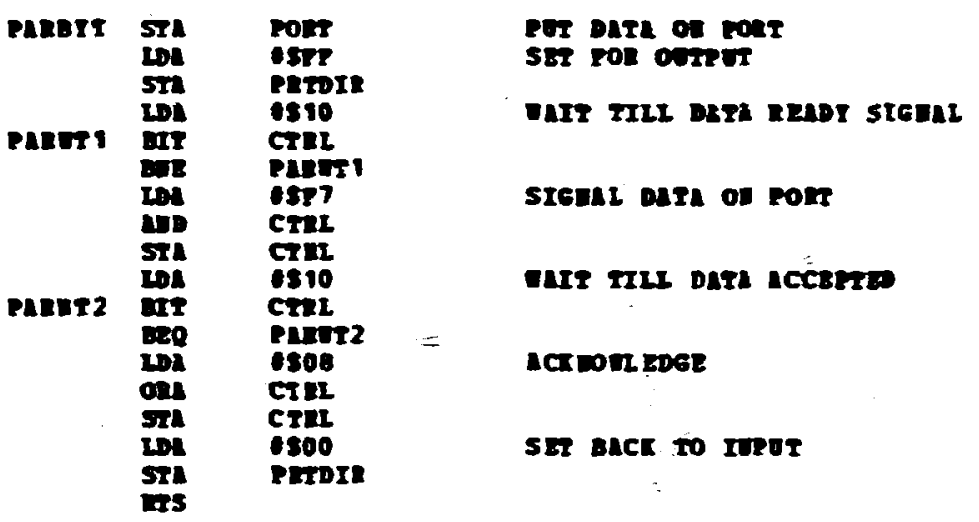

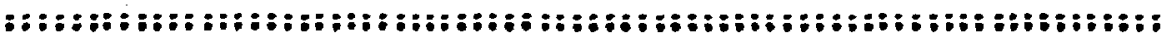

$:$

che to co

PNDOP TORD STRT

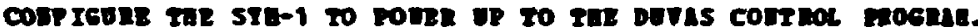

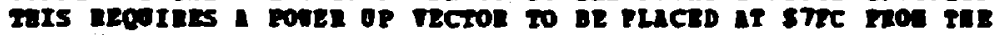

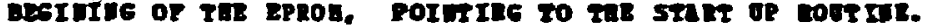

estanzestre
IDIP FOUE UP TECTOD

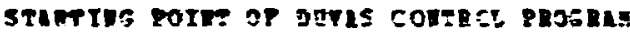


STAEOL THERE

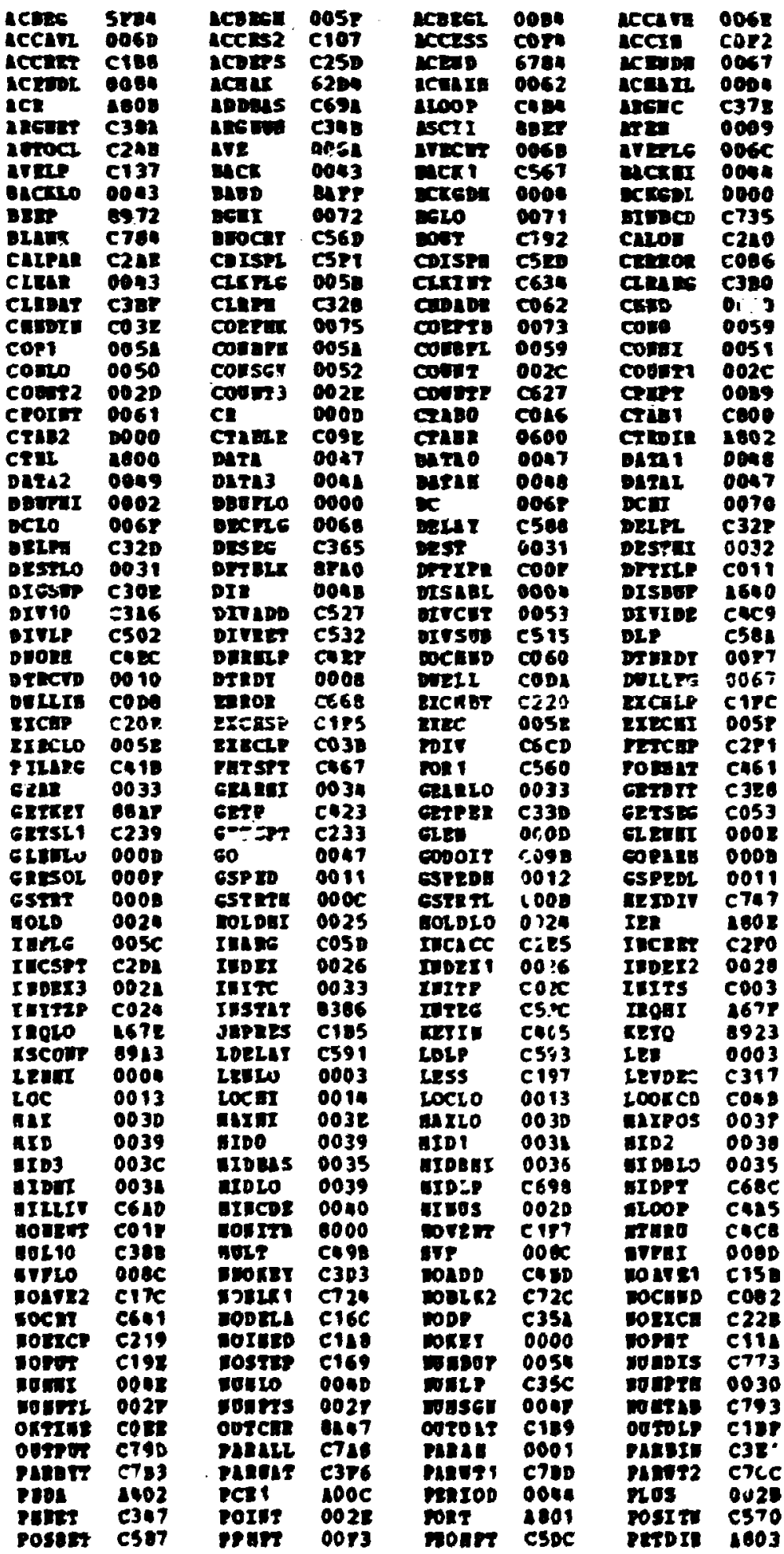




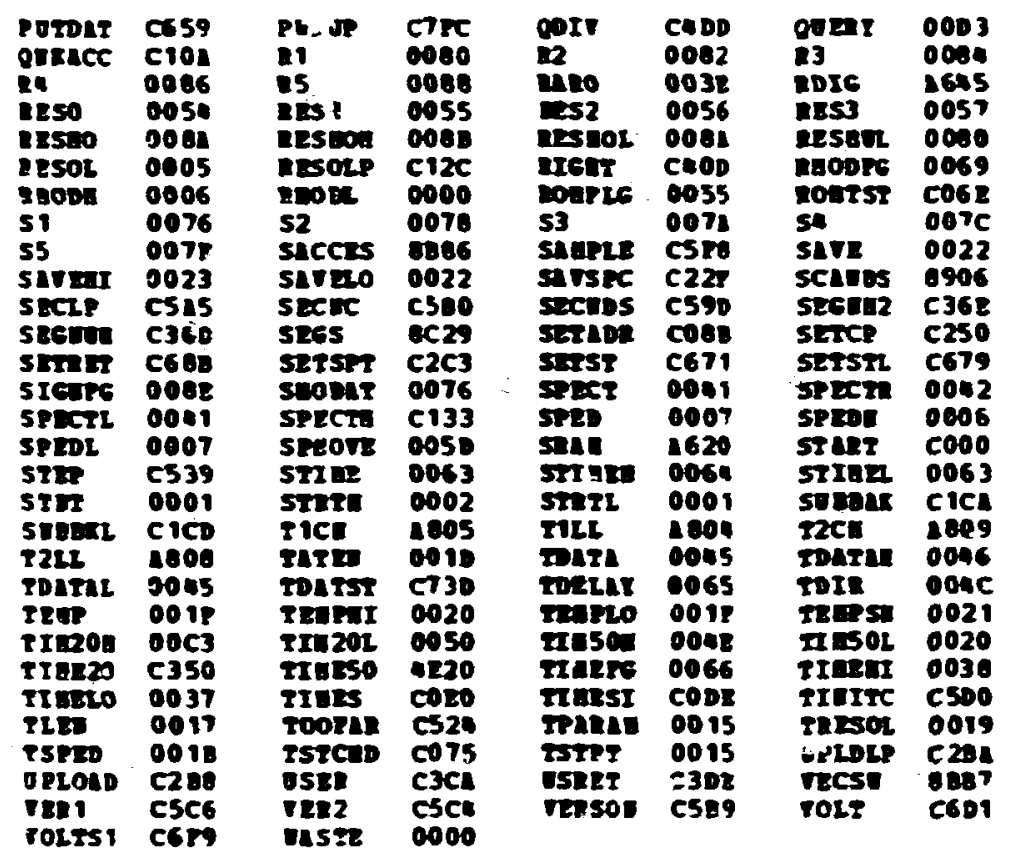


200079

sc $01 \%$

5170 a 1012

Lo: 1090921

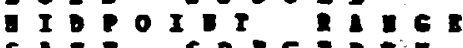

5210 5

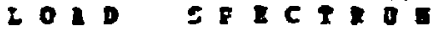

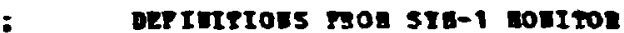

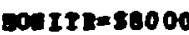

selvos $=88906$ Eartesesedi sicels = 90096 ITST $17-80306$ AR2 $=50972$ orear=sonet scotre 88943 Tregese 923 $0004=85=02$ TEse 58287 BATD=se $47 \%$ cosor-sec7o butri=seget $\mathrm{TD}=\operatorname{se} 6 \mathrm{~B}$

saz-sacte sit $=52640$ aL- 5164 24 $=51600$ DIs00\%es1680 DDIGesh64s szes= $\$ 8 C 29$ ASCII-SerEF oreveraserio s2 $14=82620$ CIDI-sceoo CIL25-50000 CTL1 $=8600$ 00587

CI: 800

Moses28 nerogesue wormT-82E

CLEL $=843$ menteses $8120=835$ uro-83C Fersasp3 aucoreso cermitases coser-s03 crvosas20 Ho2-52801 mroIses4003

Crilesse00 Crorresseoz zip-sneos ieliosne0 TLiosicos $32 \mathrm{Cl}=8 \mathrm{800}$ 3155-81006 rictesigos 0007Lo- 800 Dedrif 102

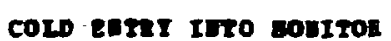

DISTLI PNOE DISU

GL LET PLOS STE RTEOAN

nofring 50 het sista deon

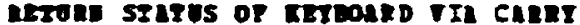

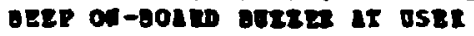

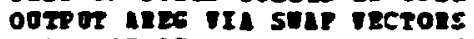

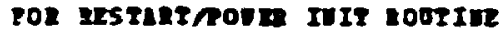

SULE VEETOES POE TTI

SLT RT DLOD RAR2

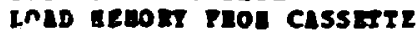

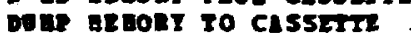

TPE ID

SRARTEG ADDEESS POE CASSETI ROOTIUES

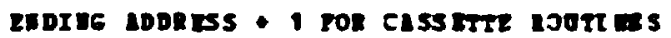

STE SESABET DISPUI DTPE

nter aOSE DIEIT

TALE JP SEREU coDS POR ASTI

HSCI gORESTONBLCE PUR SLCS

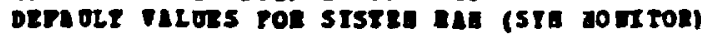

STSTER RIA ATE Comtrom

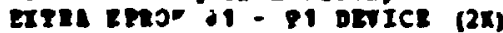

EITI EP OA 2 - P2 DETICE (2x)

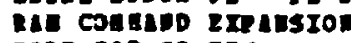

coos ros 60 KET

CODE ron Ct KE

CODE $358 \cdot$ IES

cope poe - DTCrut porns

CODE Tas ASCI DKIOLL potet

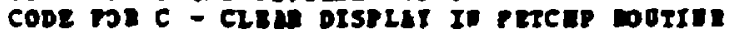

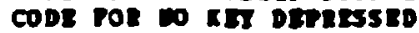

cops pos riets neor $(-\infty)$

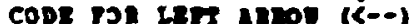

secues cope wor prom

stenter coos ron -

spentil coss ron c prons

sEGnis CODE wo 7 pante

CODE Fo2 - TEI

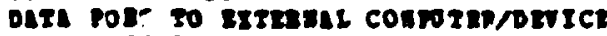

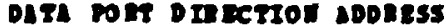

colrzel LIUT port

constiet rols diecesor

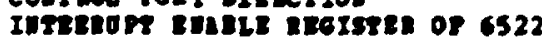

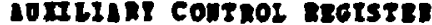

TIB 2 LITC 20

rinse 2 cosch vies

Ttuse 1 bare 50

TIIR 1 cose nien

spesing oss domes 
0000
0000
1006
1001
1000
1003
1002
4220
0020
0098
16350
0050
0003
1678
1678
0004
0008
0010
0077

0055

5 Pat

008a

D05F

6204

OODA

0062

6784

008 a

0067

0000

0006

0200

0800
DCKGDL $=500$ BCKEDE $=500$ eCr $1=\$ 100 \mathrm{C}$ PORr12=\$1001 conta2 $=\$ 2000$ DDA12 $=51003$ DDRe 2=\$1 002 TIAES0 = S4E20 TI 150L $=\$ 20$ TIA50R=ser TIEE20=8C350 TIU20L= 550 II $201=53$ IRQLO=8167E IRQEI = 1467 DISLBL $=504$ DTED $Y=508$ MrCvo $=510$ DPREDI $=577$

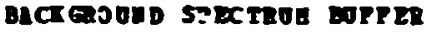

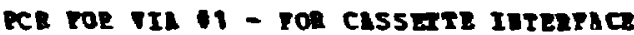

SISTEA 6522 PORT

TIE DELI POB 1/50 SEC GIU. IUTEGAET mE PEATOD

TIES DELAY TOL 1/20 SEC GI. IERESATIOE REIOD

IRQ ane vertor

SET INTEREUT DISADLE DIT

DAT READI LIER PRö $5 T$.

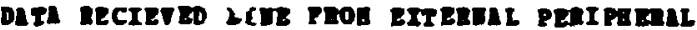
DIT TJT RBDO GAST \\ MOAPLGE $\$ 55$ \\ CCDEG 24500 \\ ICBEGL 389 \\ ICDBGE \\ ICA $I=25300$ \\ reanteste \\ MCA IIE $=862$ \\ RCEDD 26500 \\ ICETDLE 880 \\ 1CENDE= 367 \\ RMODL-SOC \\ 2.10DE $=\$ 06$ \\ TEIT $=\$ 0200$ \\ rJPBOF=80200

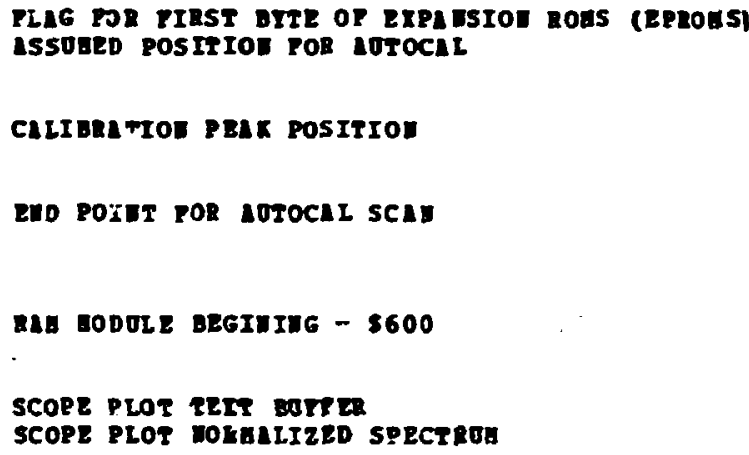

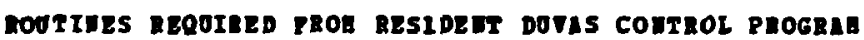




\begin{tabular}{|c|c|c|c|c|c|}
\hline \multirow[t]{2}{*}{0000} & 00 & enstz & -arte & $\mathbf{0}$ & RESET SETS TAIS DTTE TO $\$ 6 \%$ \\
\hline & & : & \multicolumn{3}{|c|}{ SPECTROE PIRAGETEES } \\
\hline $\begin{array}{l}2001 \\
0003 \\
0005 \\
0007 \\
0009\end{array}$ & $\begin{array}{ll}20 & 48 \\
88 & 03 \\
19 & 00 \\
64 & 00 \\
01 & 00\end{array}$ & $\begin{array}{l}\text { PARAE } \\
\text { STET } \\
\text { LEI } \\
\text { 2ESOL } \\
\text { SPED } \\
\text { ATER }\end{array}$ & $\begin{array}{l}\text { TORD } \\
\text {-WORD } \\
\text {-TORD } \\
\text { TORD } \\
\text { TORD }\end{array}$ & $\begin{array}{l}20000 \\
1000 \\
25 \\
100 \\
10\end{array}$ & 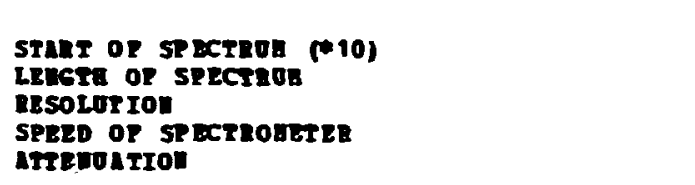 \\
\hline \multirow[t]{2}{*}{$\begin{array}{l}0001 \\
0002 \\
0003 \\
0004 \\
0007 \\
0008\end{array}$} & & \multicolumn{4}{|c|}{ 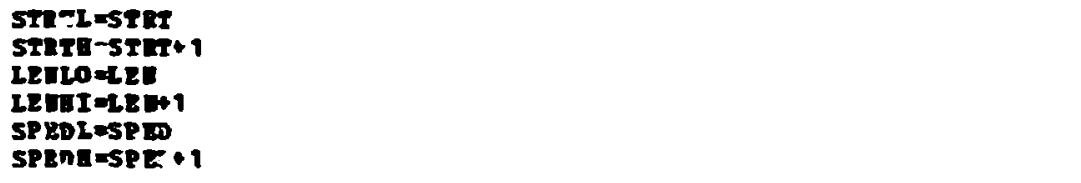 } \\
\hline & & : & \multicolumn{3}{|c|}{ FOREATTED SPECTROE PAPAGETELS } \\
\hline $\begin{array}{l}0008 \\
0000 \\
0007 \\
0011\end{array}$ & $\begin{array}{ll}20 & 03 \\
28 & 00 \\
01 & 00 \\
05 & 00\end{array}$ & $\begin{array}{l}\text { GOPARE } \\
\text { GSTET } \\
\text { GLET } \\
\text { GRESOI } \\
\text { GSPED }\end{array}$ & $\begin{array}{l}\text {-TORD } \\
\text { - IORD } \\
\text { - IORD } \\
\text { - TORD }\end{array}$ & $\begin{array}{l}800 \\
60 \\
1 \\
5\end{array}$ & $\begin{array}{l}\text { SRBT (FOR TERSIOU } 1) \\
\text { LET } \\
\text { RESOL } \\
\text { 5O/SREED }\end{array}$ \\
\hline $\begin{array}{l}0008 \\
000 c \\
0000 \\
0002 \\
0011 \\
0012\end{array}$ & & $\begin{array}{l}\text { GSTRTL= } \\
\text { GSTRTB } \\
\text { GLETLO= } \\
\text { GLEUEI= } \\
\text { GSPEDL= } \\
\text { GSPEDB= }\end{array}$ & $\begin{array}{l}\text { GSTET } \\
\text { GSTEY+1 } \\
\text { GLEA } \\
\text { GLEE+1 } \\
\text { GSPED } \\
\text { GSPED+1 }\end{array}$ & & \\
\hline $\begin{array}{l}0013 \\
0014\end{array}$ & $\begin{array}{l}00 \\
00\end{array}$ & $\begin{array}{l}\text { LOC } \\
\text { LOCLO } \\
\text { LOCHI }\end{array}$ & $\begin{array}{l}\text {-BITE } \\
\text {-BrTz }\end{array}$ & $\begin{array}{l}0 \\
0\end{array}$ & COBREAT SPECTROAETER SETtITG - SET OT CAL \\
\hline $\begin{array}{l}0015 \\
0017 \\
0019 \\
0018 \\
0010\end{array}$ & $\begin{array}{ll}20 & 12 \\
28 & 03 \\
19 & 00 \\
64 & 00 \\
01 & 00\end{array}$ & $\begin{array}{l}\text { TPLRAB } \\
\text { TETLT } \\
\text { TLET } \\
\text { TEBSOL } \\
\text { TSPED } \\
\text { TATED }\end{array}$ & $\begin{array}{l}\text { TORD } \\
\text {-TORD } \\
\text {-TORD } \\
\text { - MORD } \\
\text { - MOSD }\end{array}$ & $\begin{array}{l}20000 \\
1000 \\
25 \\
100 \\
10\end{array}$ & TEGPORAY PARABETER STORAG POH BACKGEOED \\
\hline $\begin{array}{l}0017 \\
0020 \\
0021\end{array}$ & $\begin{array}{l}00 \\
00 \\
00\end{array}$ & $\begin{array}{l}\text { TEUPLO } \\
\text { TEEPHI } \\
\text { TEEPSE } \\
\text { SAVE }\end{array}$ & $\begin{array}{l}\text { DIRE } \\
\text {-BITE } \\
\text {-ATTE }\end{array}$ & $\begin{array}{l}n \\
0 \\
0\end{array}$ & $\begin{array}{l}\text { POR IUTERKEDITE RESUI.TS } \\
\text { (TOR TOIPLE PRECISION }\end{array}$ \\
\hline $\begin{array}{l}0022 \\
0023\end{array}$ & $\begin{array}{l}00 \\
00\end{array}$ & $\begin{array}{l}\text { SATELC } \\
\text { SIVEI } \\
\text { BOLD }\end{array}$ & $\begin{array}{l}-857 z \\
.812 z\end{array}$ & 0 & SZCOTDLAI STOMLE \\
\hline $\begin{array}{l}0025 \\
0025\end{array}$ & $\begin{array}{l}00 \\
00\end{array}$ & $\begin{array}{l}\text { HOLDLC } \\
\text { HOLDHI } \\
\text { InDEI }\end{array}$ & $\begin{array}{l}\text { extz } \\
\text { - BrTz }\end{array}$ & : & OSED EY SECIDS \\
\hline $\begin{array}{l}0026 \\
0027 \\
0028 \\
0029 \\
0021 \\
0028\end{array}$ & $\begin{array}{l}00 \\
00 \\
00 \\
00 \\
00 \\
00\end{array}$ & $\begin{array}{l}\text { INDEX } 1 \\
\text { ITOEX } 2 \\
\text { ITOEX } 3 \\
\text { COONI }\end{array}$ & 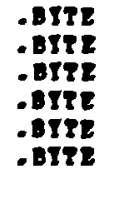 & $\begin{array}{l}0 \\
0 \\
0 \\
0 \\
0 \\
0\end{array}$ & $\begin{array}{l}\text { ARII I IDICIES } \\
\text { (ALSO ADDESS poITrERS) }\end{array}$ \\
\hline $\begin{array}{l}0025 \\
0020 \\
0022\end{array}$ & $\begin{array}{l}00 \\
00 \\
00\end{array}$ & $\begin{array}{l}\cos 21 \\
\operatorname{coovr2} \\
\operatorname{coovr} 3\end{array}$ & $\begin{array}{l}\text {.Brtz } \\
\text {.0r8E } \\
\text {.erte }\end{array}$ & $\begin{array}{l}0 \\
0 \\
0\end{array}$ & LOOP COOHILIS \\
\hline
\end{tabular}




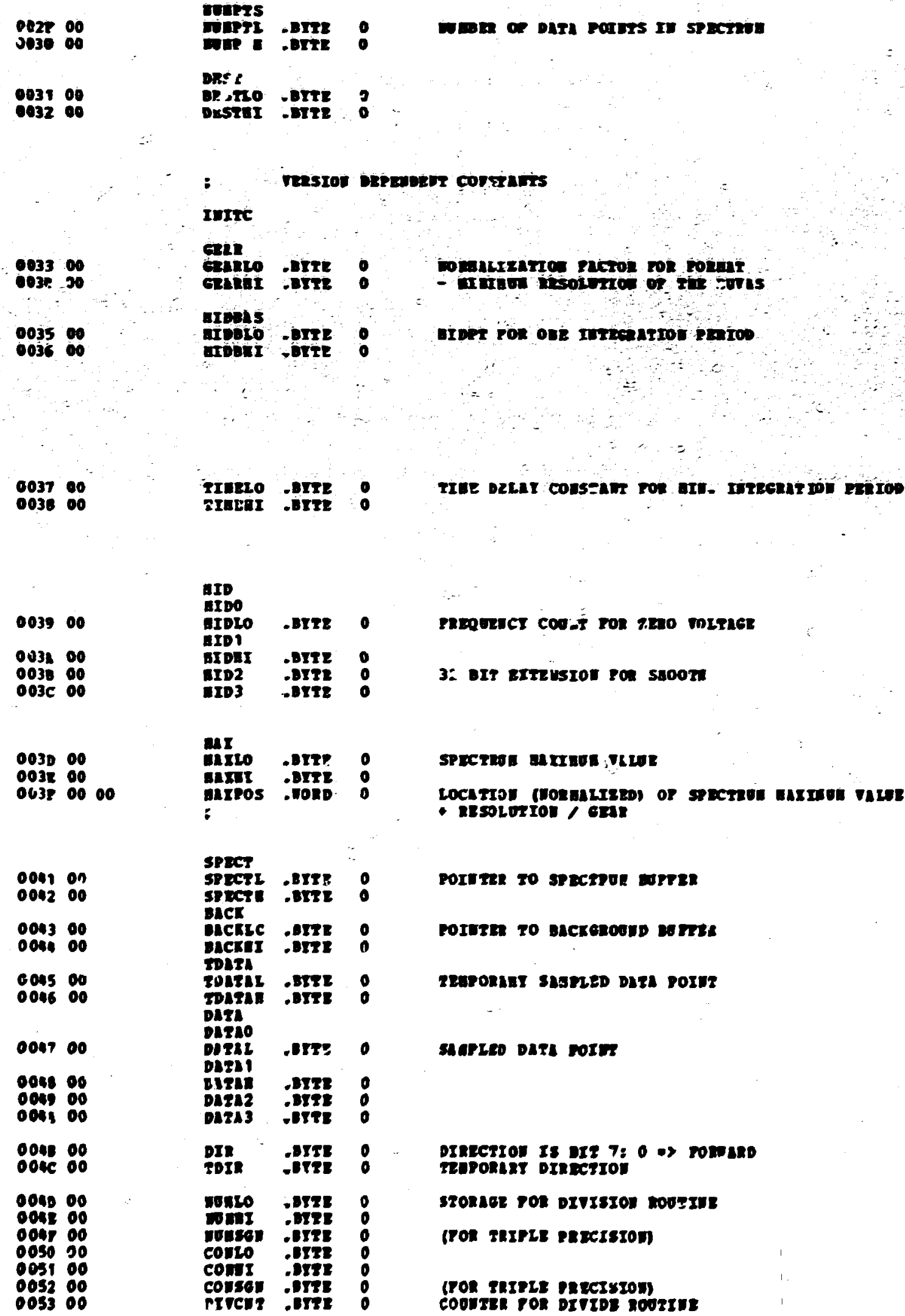




\begin{tabular}{|c|c|c|c|c|c|}
\hline 0050 & 00 & $\begin{array}{l}\text { Reso } \\
\text { nuabur } \\
\text { REs I }\end{array}$ & & $\mathbf{J}$ & 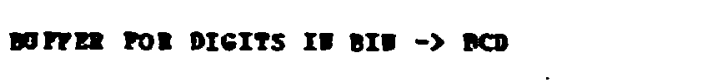 \\
\hline 0055 & 00 & D252 & .arre & $\mathbf{0}$ & ITD STOLLEE POA DOST ROOTIRE \\
\hline 0056 & 00 & & .0752 & $\mathbf{0}$ & \\
\hline $\begin{array}{l}0057 \\
0058\end{array}$ & $\begin{array}{l}00 \\
00\end{array}$ & ] & $\begin{array}{l}\text {-orre } \\
\text {-exre }\end{array}$ & 0 & \\
\hline 0059 & $\mathbf{0 0}$ & $\begin{array}{l}\text { Cono } \\
\text { Courez } \\
\text { cont }\end{array}$ & -Berz & 0 & COESTINT DOTTE TOR ITIEASE DITISTON \\
\hline 0051 & 00 & combra & .arte & 0 & IDD FOA EUL ROUTIE \\
\hline 0058 & 00 & CLRERG & $.075 z$ & 0 & $0 \Rightarrow \operatorname{sTLY} I \|$ LOOP: $-1 \Rightarrow$ STOP TPC SAERE \\
\hline $\begin{array}{l}005 c \\
0050\end{array}$ & $\begin{array}{l}\infty 0 \\
00\end{array}$ & $\begin{array}{l}\text { IAPLE } \\
\text { SPEOTE }\end{array}$ & $\begin{array}{l}-87 T 2 \\
-\operatorname{arr2}\end{array}$ & $\stackrel{0}{0}$ & 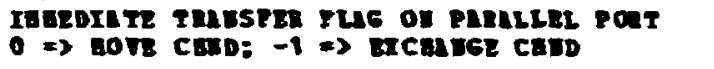 \\
\hline $\begin{array}{l}0058 \\
005 \% \\
0060 \\
0061\end{array}$ & $\begin{array}{l}00 \\
00 \\
00 \\
0000\end{array}$ & 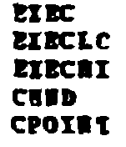 & 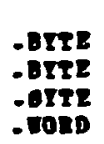 & $\begin{array}{l}0 \\
0 \\
0 \\
0\end{array}$ & 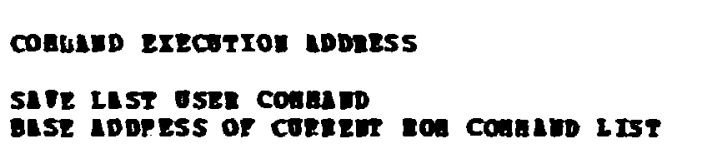 \\
\hline $\begin{array}{l}0063 \\
0064 \\
0065 \\
0065 \\
0067 \\
0068 \\
0069\end{array}$ & $\begin{array}{l}00 \\
00 \\
00 \\
00 \\
00 \\
00 \\
00\end{array}$ & 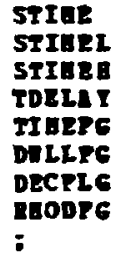 & 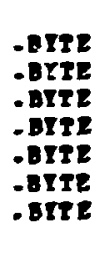 & $\begin{array}{l}0 \\
0 \\
0 \\
0 \\
0 \\
0 \\
0\end{array}$ & 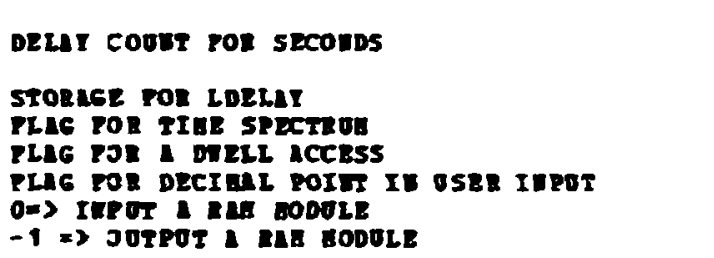 \\
\hline $\begin{array}{l}0061 \\
0068 \\
006 \mathrm{C} \\
0060 \\
0062\end{array}$ & $\begin{array}{l}00 \\
00 \\
00 \\
00 \\
00\end{array}$ & $\begin{array}{l}\text { ITE } \\
\text { IVETT } \\
\text { IVETLG } \\
\text { ICCAII } \\
\text { ICCAVA }\end{array}$ & $\begin{array}{l}\text { OTTE } \\
\text {-DTTE } \\
\text {-OITE } \\
\text { - BTTE } \\
\text {-BTTE }\end{array}$ & $\begin{array}{l}0 \\
0 \\
0 \\
0 \\
0\end{array}$ & 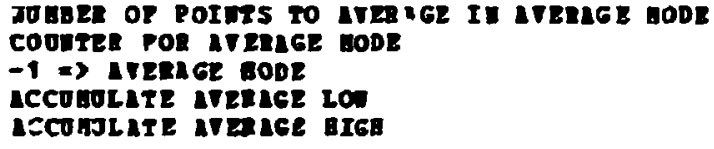 \\
\hline $\begin{array}{l}006 \% \\
0070\end{array}$ & $\begin{array}{l}00 \\
00\end{array}$ & $\begin{array}{l}\text { DC } \\
\text { DCLO } \\
\text { DCRI }\end{array}$ & $\begin{array}{l}\text {-BTTE } \\
\text {-OTTE }\end{array}$ & $\begin{array}{l}0 \\
0\end{array}$ & DOEL ITE CONCENTRATIOL COISTISTS \\
\hline $\begin{array}{l}0071 \\
0072\end{array}$ & $\begin{array}{l}00 \\
00\end{array}$ & $\begin{array}{l}\text { BGLO } \\
\text { BgRI }\end{array}$ & $\begin{array}{l}\text { Arte } \\
\text {-arte }\end{array}$ & $\begin{array}{l}0 \\
0\end{array}$ & \\
\hline $\begin{array}{l}0073 \\
0075\end{array}$ & $\begin{array}{ll}00 & 00 \\
00\end{array}$ & $\begin{array}{l}\text { COEFIA } \\
\text { COLPAI } \\
\text { SEODIT }\end{array}$ & $\begin{array}{l}\text {. TOSD } \\
\text {.OTRE }\end{array}$ & $\begin{array}{l}0 \\
0\end{array}$ & 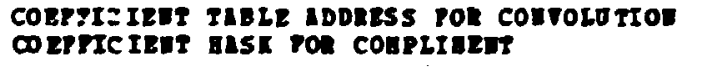 \\
\hline $\begin{array}{l}0075 \\
0078 \\
0071 \\
007 c \\
0078 \\
0078\end{array}$ & $\begin{array}{ll}00 & 02 \\
00 & 00 \\
00 & 00 \\
00 & 00 \\
00 & 00\end{array}$ & $\begin{array}{l}\mathbf{5 1} \\
\mathbf{5 2} \\
\mathbf{3 3} \\
\mathbf{5 4} \\
\mathbf{3 5} \\
\text { BESEOL }\end{array}$ & $\begin{array}{l}\text { - TORD } \\
\text { - TORD } \\
\text {-7020 } \\
\text { - DORD } \\
\text { - TORD }\end{array}$ & $\begin{array}{l}0 \\
0 \\
0 \\
0 \\
0\end{array}$ & 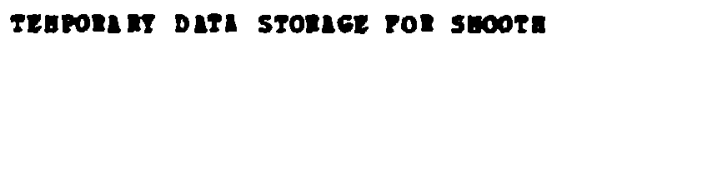 \\
\hline $\begin{array}{l}0080 \\
0082 \\
0083 \\
0084 \\
j 066 \\
0088\end{array}$ & $\begin{array}{ll}00 & 00 \\
00 & 00 \\
00 & 00 \\
00 & 00 \\
00 & 00\end{array}$ & $\begin{array}{l}R 1 \\
R 2 \\
83 \\
R 4 \\
R 3 \\
\text { RESPO }\end{array}$ & $\begin{array}{l}\text { TORD } \\
\text { TORD } \\
\text {-WORD } \\
\text { TORD } \\
\text { - WORD }\end{array}$ & $\begin{array}{l}0 \\
0 \\
0 \\
0 \\
0\end{array}$ & aesuLt or $S(I) * \cos T(I)$ \\
\hline $\begin{array}{l}0091 \\
0008\end{array}$ & $\begin{array}{l}00 \\
00\end{array}$ & $\begin{array}{l}\text { RESHO I } \\
\text { Azsho }\end{array}$ & $\begin{array}{l}\text {-ArTz } \\
\text {.BTTE }\end{array}$ & $\begin{array}{l}0 \\
0\end{array}$ & Resoht or co \\
\hline
\end{tabular}




\begin{tabular}{|c|c|c|}
\hline $\begin{array}{ll}000 x & 00 \\
000 D & 00\end{array}$ & $\begin{array}{l}\text { GTP } \\
\text { GrPLo } \\
\text { atral }\end{array}$ & $\begin{array}{l}\text {-BTTE } \\
\text {-BTTE }\end{array}$ \\
\hline TOOE NO & SIGETG & .ATTE \\
\hline
\end{tabular}

$\operatorname{0og} \mathbf{P} 00$

009000

009100

009200

009300

0094 00

009500

009600

009700

0098 00

009900

009100
aI

aITL -ATTE 0

Consol -arte 0

cone -atre 0

scpoor -eTre 0

ange

RALEL -BTTE

RAESE - BTTE 0

DISPTE -ATTE 0

SCPCER -arTE 0

SCPDP -OITE 0

SRASS -OTTE 0

IITCTT -8YTE 0 ararade fol scopz oOtent

consor ron scope plot

DOAnILIEATIOA COUL FOR SCOPE OOTPUT

LEDSTE of SCOPE SCA

MAEE OF DATA

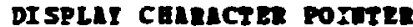

DISPLAT CODE TOR SCOPE

SCOPE DeCIALL POIE COOE - 500 OR 580

DIt MAST POR TETT 
$-55000$

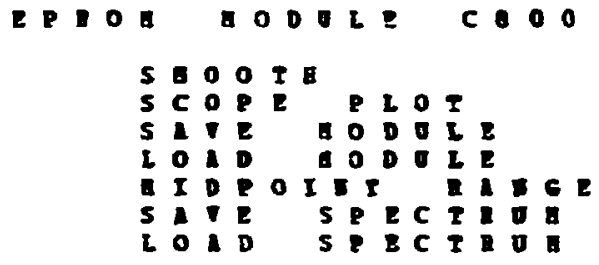

Cogmato ra

cearent rone or eaca zuset

$\cdots$

(Cosand code)

COTRIU2 LDQRES LOI:

crovtrar adoress HIGD

000055

C801 35

C902 $17 \mathrm{CB}$

coos 39

$-805 \quad 3 \mathrm{cg}$

c807 52

co0 $13 \mathrm{CC}$ caol it

C80B $65 \mathrm{CC}$ caob ic

$\cos 53 \mathrm{Cr}$ colo 12

car1 $16 \mathrm{cC}$

$\cos 313$

coin 12 cC

c816 00

$\cdots$

\begin{tabular}{|c|c|c|c|}
\hline IELE & 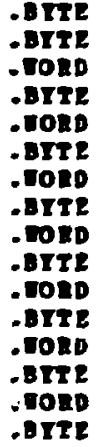 & 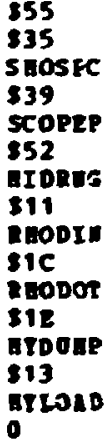 & 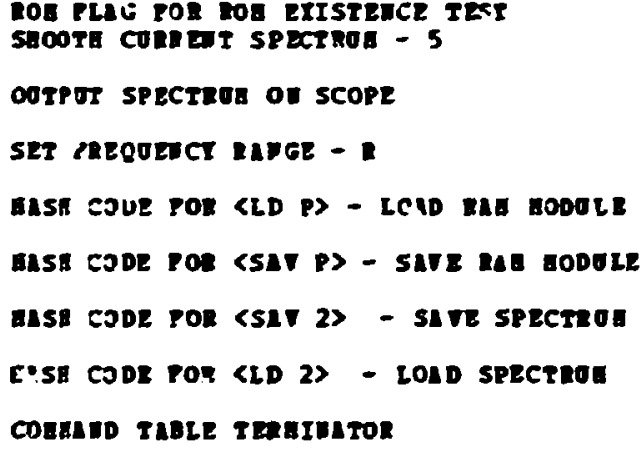 \\
\hline
\end{tabular}

QTTE O CDILIUD TABLE TEAIEATOR

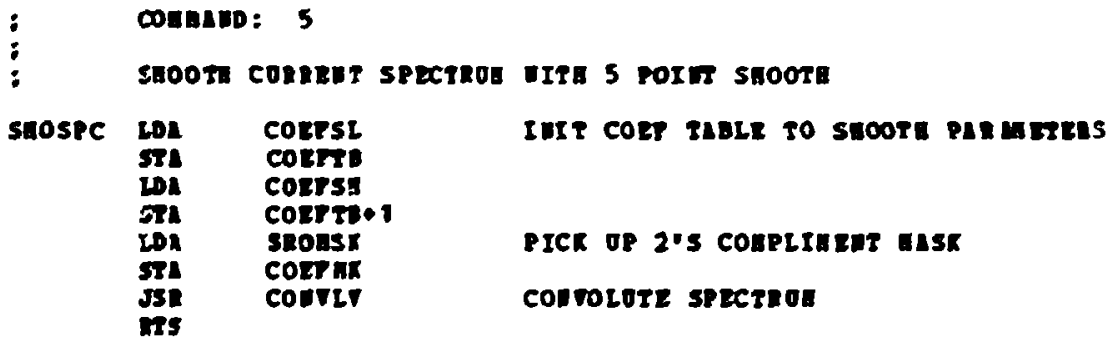




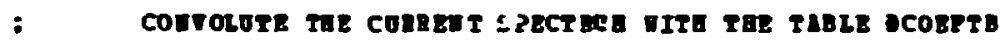

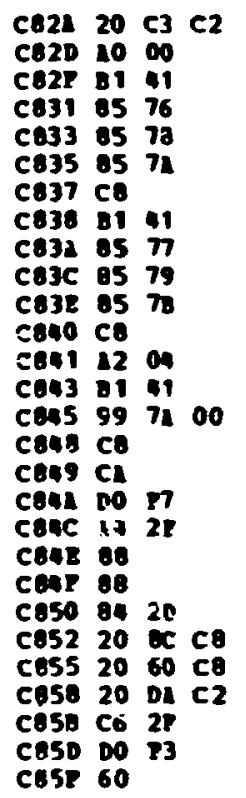

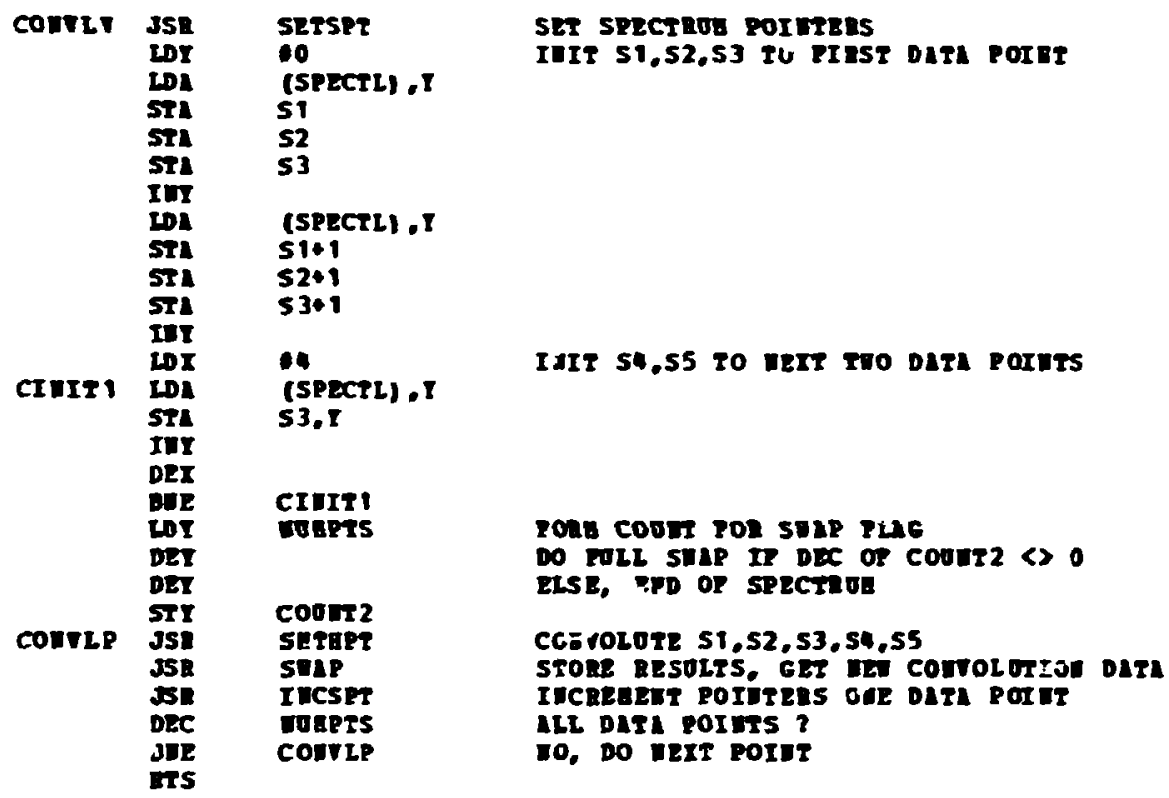

C460 1000

C862 18

Ce63 is on

C865 6539

c867 9 : 41

C869 C8

co61 158

C86C 6531

C862 91 औ?

Ca70 1280

Co72 8580

ca7. 95 7E

C876 28

C877 DO 89

C879 C6 20

co7B 70 OC

C87D 10 of

carp : : 4

C881 857

$\mathrm{Cos} C \mathrm{CB}$

C8B० 81 เ1

C986 os 7

c688 60

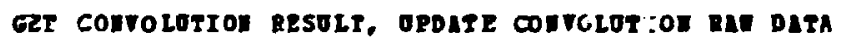

$\sin A$

10

GOTE RESULT ITTO SPECTEE

LI

IDD BACK II TAE GIDDLE DISPLACEAET

BIDLO

(SPECRL), I

ADO BACK TH TAE GTODLE DISPLACELET

RESHOR

GTOEI

(SPEC PL) , I

$0-8$

$51+10, x$

SHAP $S(I) \quad<-S(I+I) \quad 1<E I<-4$

SULLP LD:

$51+8,1$

STAPLP

cosrez

SPECHD

66

(SPECTL), Y

55

no, LEATE COPY OP 55

TES. PICK OP IEE 55 TNOA SPECTRE

POT DIRECTLT ITTO PLACE

(SPECTL), T

$55+1$

C889 2620

cese 60

SPECWD IF:

$\cos \cos _{2}$

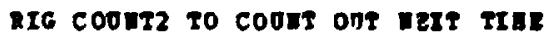

no specten porats to stip in eorres 
Cacc $\triangle 905$

ceos o5 $2 \mathrm{C}$

C8so 1976

C892 8526

ceg4 1920

cess 8521

cess 1900

cog1 0527

cage 1528

cest 1573

colo 8520

cosi 1570

cos 8529

Con 1000

Cana BI 26

cens 85 i7

c8nc 2626

Canz bi 26

C8Bo 85 48

Cas2 1002

cest $10 \mathrm{PT}$

coss of 19

ceve 84 il

cosL 2626

CobC 12 FC

ces: 38

C80P 85 A8

cac1 $=530$

cec3 95 AD

cec5 28

cecs $00 \mathrm{~F}$

cace 1000

coca al 28

cecc 8559

C8CE 2628

CODO DO 02

C8D2 2629

CoD 8128

Cops 855

CADB 2628

CODA DO 02

CaDC 2629

CADE 20 9a CA

C8E1 1000

Cos3 $\triangle 5 \quad 56$

ces5 1121

C8E7 262

cors is 57

Cosp 912

CAED 2621

cone c6 $x$

CEP1 DO B

cer3 848

c8rs 84

cop7 15 75

$\cos 1280$

cos: 98

cerc ro nc

cors a

cope 18

c90; 9003

C902 $2024 \mathrm{c9}$

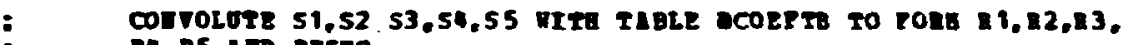
: Ri, 85 ID abseo

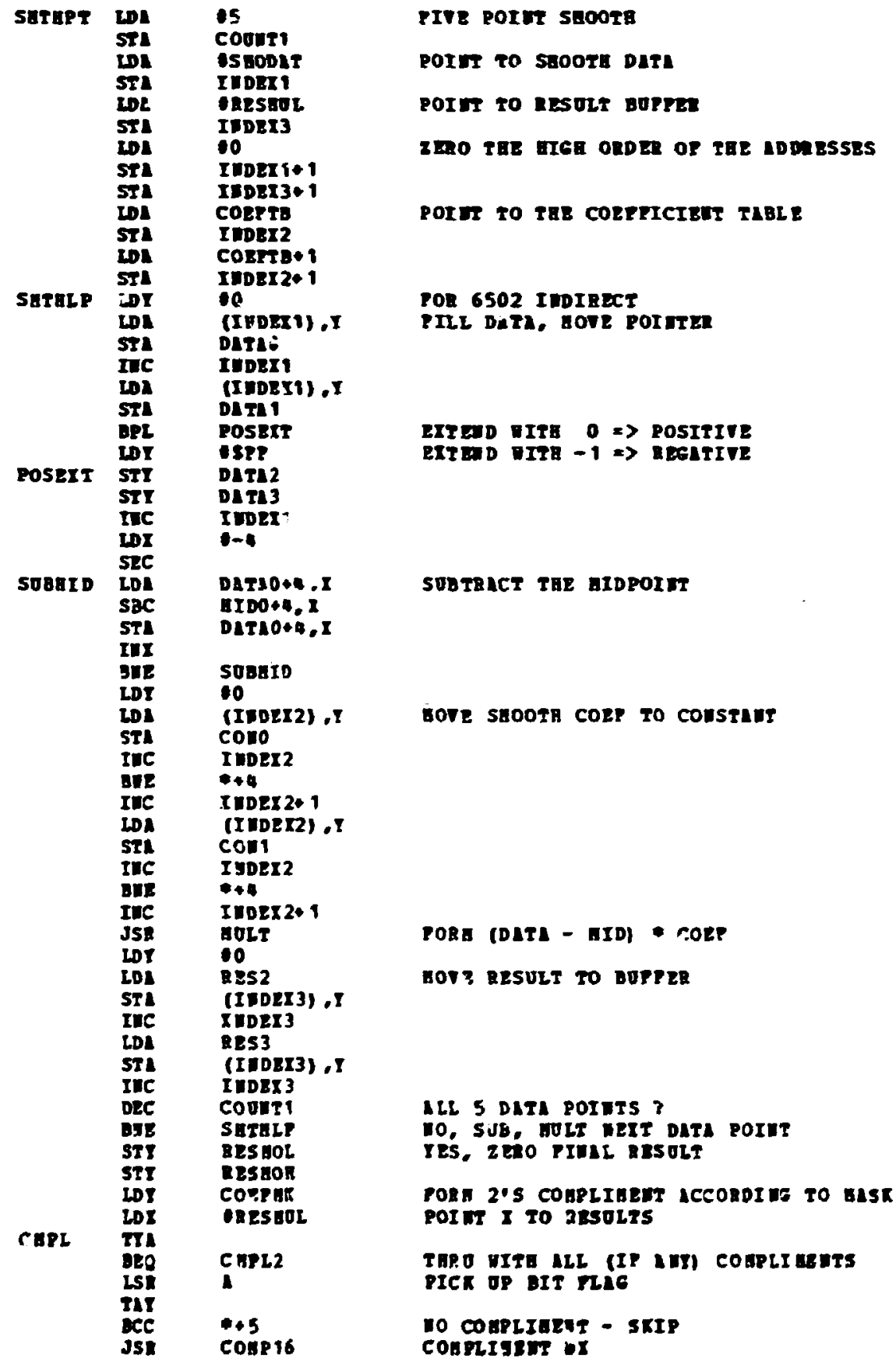




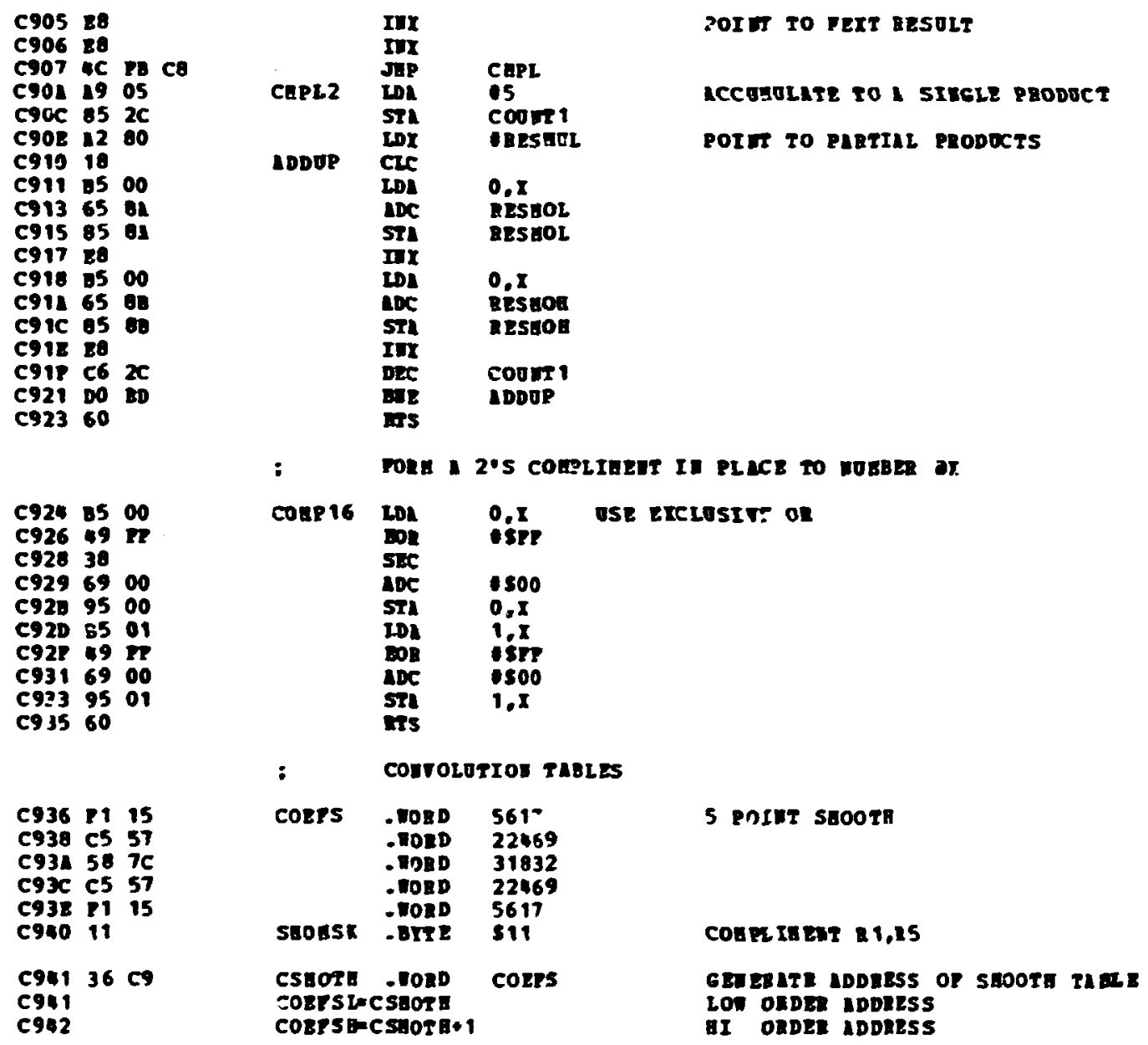


101

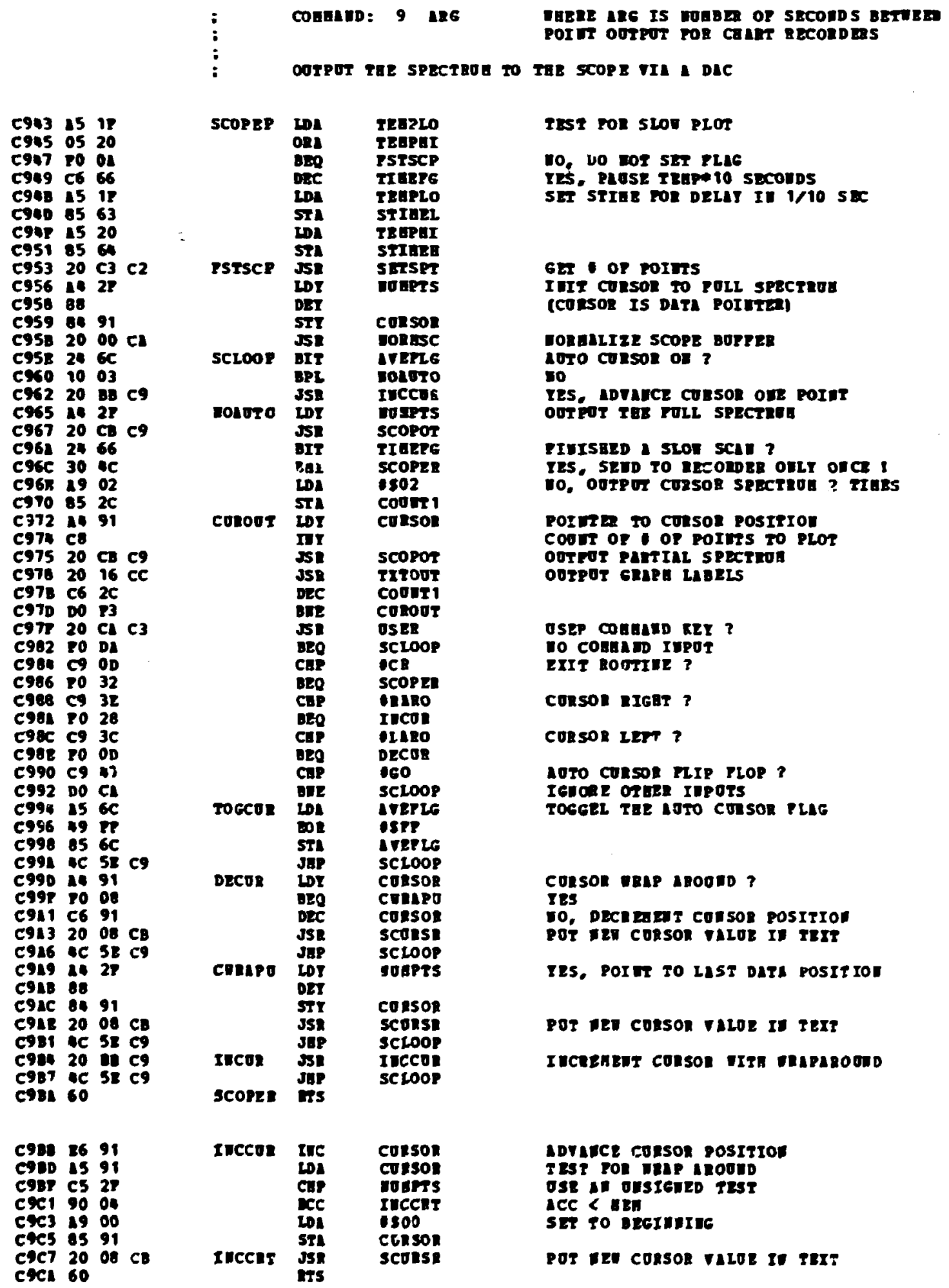


102

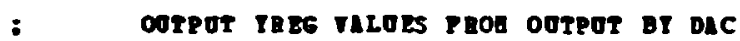

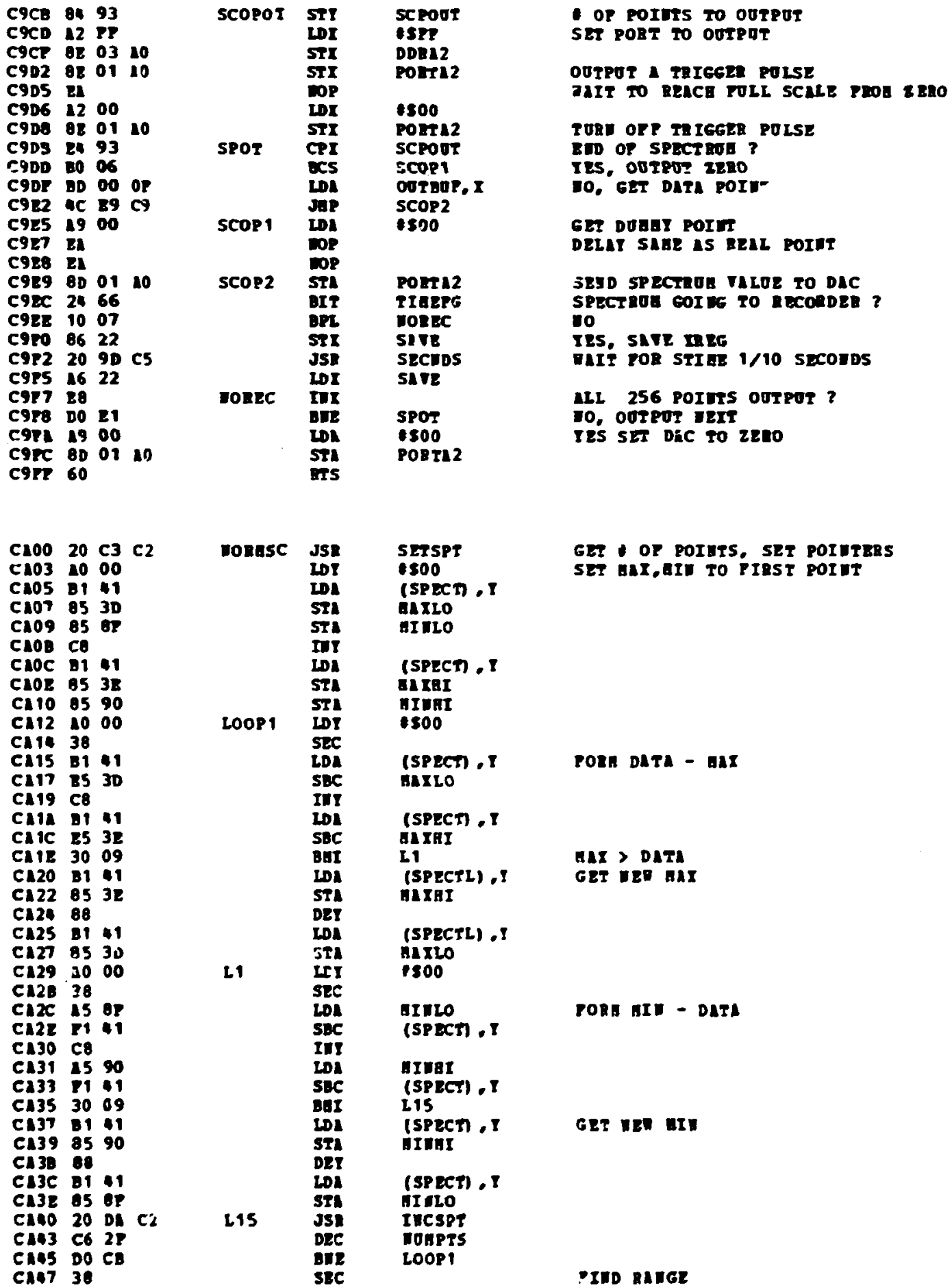




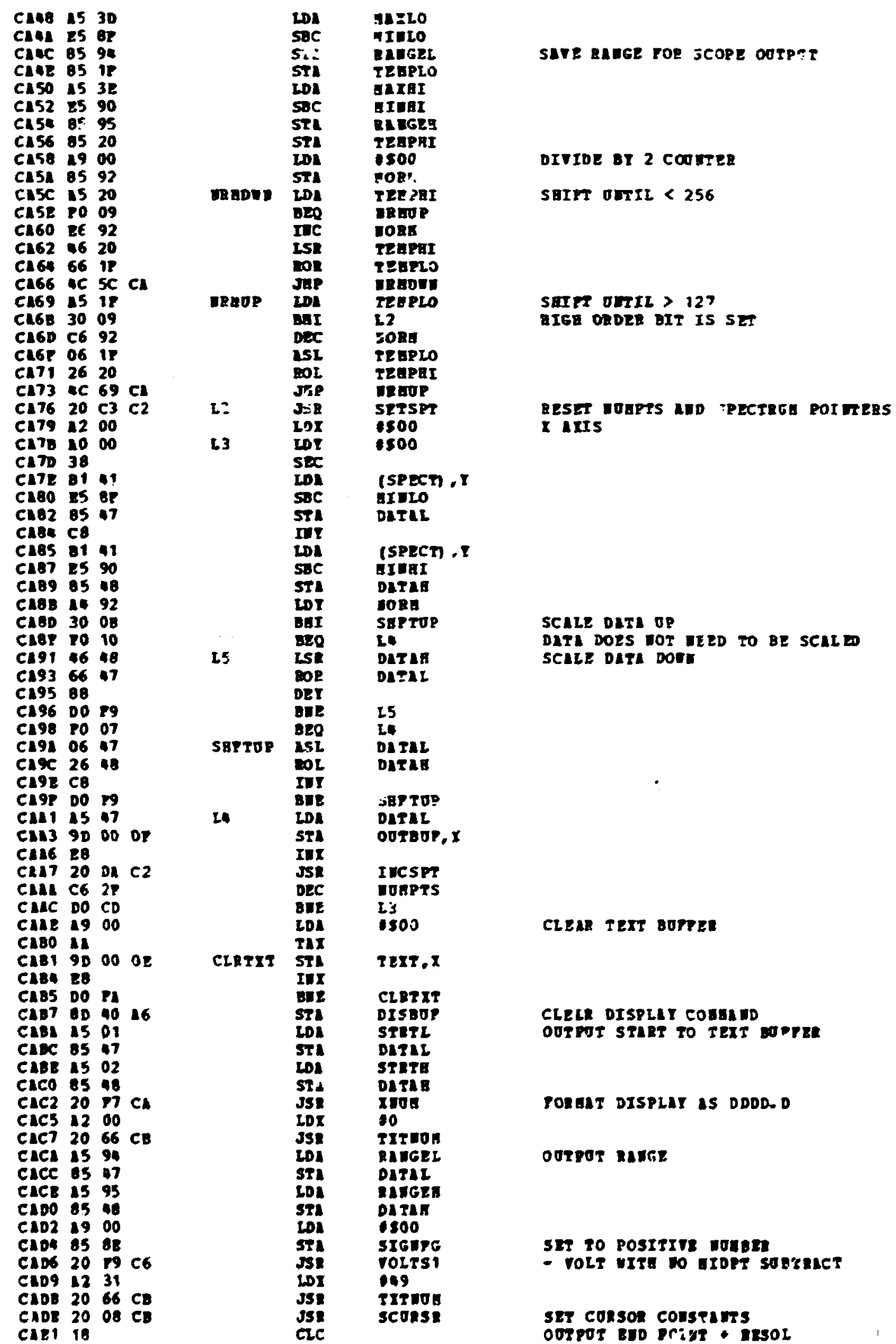




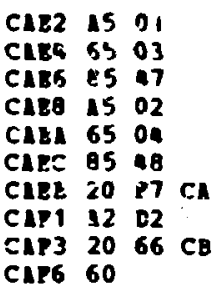

$\begin{array}{lllll}20 & 35 \mathrm{c7}\end{array}$

CaPA 1900

CAPC 8D $10 \quad 16$

CATP 1D 14 A6

$\mathrm{CBO2}$ OS 90

CBOA BD A4 16

C807 60

C908 1262

CBOA $10 \$ 1$

CROC $2014 \mathrm{CB}$

CBOP IS 05

C811 8547

col3 159 .

C815 8559

CB17 1900

CB19 BE 48

CB1D 6549

Ca10 85 \&

Co1P 8551

Co21 20 98 $\mathrm{CQ}$

CB24 18

CB25 1501

C827 6554

CD79 8547

CBA 150 ?

CQ2D $655 j$

C82F 85 a8

CB31 20 :7 CA

CB34 1269

C836 $2066 \mathrm{CB}$

$\cos 10 \quad 3 \mathrm{C}$

CB38 20 at $C B$

C83E 1046

$\cos 20$ il CB

$\mathrm{CBA}_{3} 20 \mathrm{C} 6 \mathrm{C2}$

C846 1591

CB48 OA

C849 9002

Ca48 $26 \quad 42$

Cand 654

cent 1000

CBS1 $31 \div 1$

Ca53 $85 \quad 47$

CB55 $c 8$

Co56 114

cass 65

Ca5: 20 D1 C6

Ca50 1241

Casp $2066 \mathrm{CB}$

$\begin{array}{llll}C 262 & \mathrm{C3} & \mathrm{C2}\end{array}$

C865 60

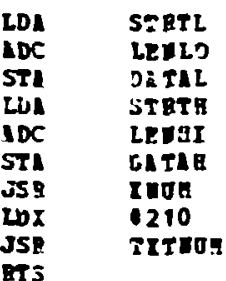

Tara

xuda. Po

TATA ITTS DDDD. D

J5B BI IPCD

1500

DI SB DP

DISBOT+4

$\begin{array}{ll}\text { ORE } & \text { IS80 } \\ \text { STI } & \text { DISOOT+E }\end{array}$

$\begin{array}{ll}\text { ORE } & 1380 \\ \text { STI } & \text { DrSOOTEE }\end{array}$

SET DISPLLY DITE DEC :DI

CLEAR PBOAPT CHABACTER

IUSET PER:OD

exs

SCO8SR. PORHAT COASOB VLLOE IU TRYT

SCOkSR

Lot

LOT

JSE

LTI

STI

LOA

STA

LDN

STI

ST

STI

S2I

Cle

LDI SERT

IDC BESO

STI DLTAL

LDL STBTH

IDC RES 1

STI DATAR

JSB INOH

LDX IDS

JSR TITUOH

IDI ESCPBP-TITTAB

TITAOT

ISCPEO-TITTAB

TITHOT

SETSPT + 3

:

CORSOR

1

SC1

specta

SPECTL

$\$ 800$

(CPECT) , I

DATAL

(Spect) 1

DATAR

rols

161

ExT NOH

SETSPI positiol TA TEIT

OOTPOT I

FORE CORSOR RESOL

(8) aIf 0osmitres)

ZERO BIGE ORDERS

STLET * CORSOR+RESOL

POEMAT POSLI INI

OOTPOT I

OOPPOF =

RESET POI TERS, DO WOT EE PORAT

YOTE: SPECTL HOST BE OP PORA STBOO.

PICK oP BITE POIUTER

CORSOR II MONDS

nOT II OPPLA FiLP

POINC IYTO OPPER KLIF OP SPECSOE

cossor $2 \cdot \$ 00$

OUTPOT DITA

CONVEAT is gILLIVOLT POREAT 
: TETTEG. POTE SCOPE SODES FOR DISPLAT TO =EIT.

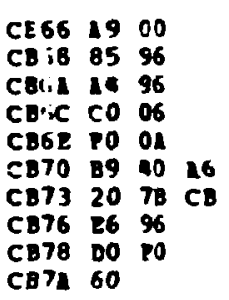

CB7B $\$ 597$

CD70 1000

CB7P 1597

CB81 1002

C583 1040

Ce85 8c 98

C887 1597

C889 297

CaSB $P 0 \quad 32$

CB8D Cn 40

CB8r 10 a2

CB91 1009

C893 $\mathrm{ng} 29 \mathrm{AC}$

C896 1003

C898 88

C899 DO 79

C89B 8497

CB9D 98

CB9E OI

CB9P 01

CBAO 18

CBA1 6597

$\cos 18$

CBI4 19 O5

CBL6 8591

C8L8 89 CB CB

CBAB OD 00 OE

CBAE:

\begin{tabular}{|c|c|c|}
\hline TITUOE & LD: & $\$ 500$ \\
\hline & ST: & DISPTA \\
\hline TITELP & $\begin{array}{l}\text { LDI } \\
\text { CPI }\end{array}$ & $\begin{array}{l}\text { DISPTA } \\
\text { S06 }\end{array}$ \\
\hline & $\begin{array}{l}\text { Beg } \\
\text { LD }\end{array}$ & $\begin{array}{l}\text { TITWET } \\
\text { DISBOE. }\end{array}$ \\
\hline & JSR & TITCAB \\
\hline & $\begin{array}{l}\text { zuc } \\
\text { Baz }\end{array}$ & $\begin{array}{l}\text { DISETR } \\
\text { :IILP }\end{array}$ \\
\hline
\end{tabular}

TITCA

STA

LDI

LDI

BPL

MODEC ST

STI

LDI

B80

Cup

DEO

IDT

TDIGLP CAP

CEP

DEY

BIE

TSEGO: ST

STI

iri

MSL

CLC

ADC

TI

TXTHOV LDI

ST 1

TXTSEP WI

STI

IEX

TITCET

TXTT18,

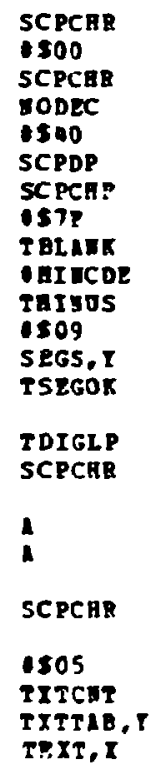

SATE DISPLEY CBRBACTER

ISSUAE DO DECIMAL POI IT

TEXT POB $\$ 80$ DF CODE

WO DECIULL POIUT IU CODE

SCORE CODE YOR A DECIML POIST

SATE POR OUTPOT LATBE

STRIP AaI DECIAL Por IT

UOLL CHABICTER

DEETIVE VOLTEE

MOST BE $\triangle$ DIGIT, LOCK OP TAOE

SEABCH STA TABLE OP DISPLAT CODES

POO DD CODE

LOOK OILI I I WHEES

DEPLOLT IS ZERO

PORA 5* IEDEI I

$\bullet 2$

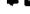

$\bullet 5$

SJTE SCOPE CODES, TITTAB, T to TEXT.

CBAP C8

C880 C6 91

C882 DO $P B$

Cese 1598

CAB6 9D OS OE

C889 88

CaAs 9u 00 OE

CDBD 28

IIIS 60

Case $10 \quad 32$

CBC1 DO E1

cec3 4037

Cocs 1020

Cact 8598

$\therefore C 970$ D9

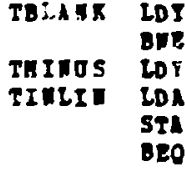

TrTen

IITSIP

SCPOP

TExT, $x$

HOVE DECIHAL POIUT
SC PBLR-TXTIL

TITHOV

ISCPHIN-TXTTHB

1500

SEPDP

retror 


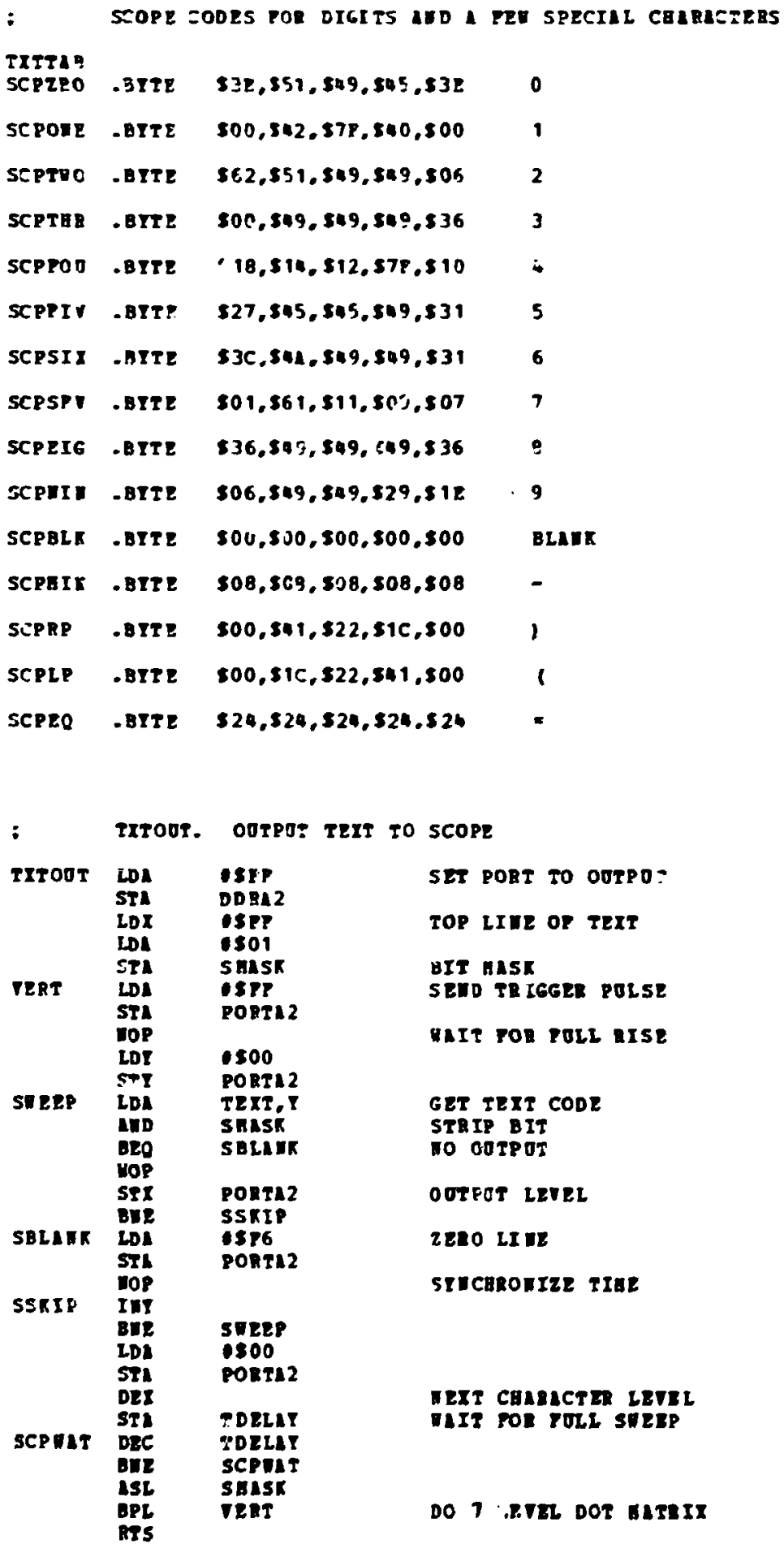




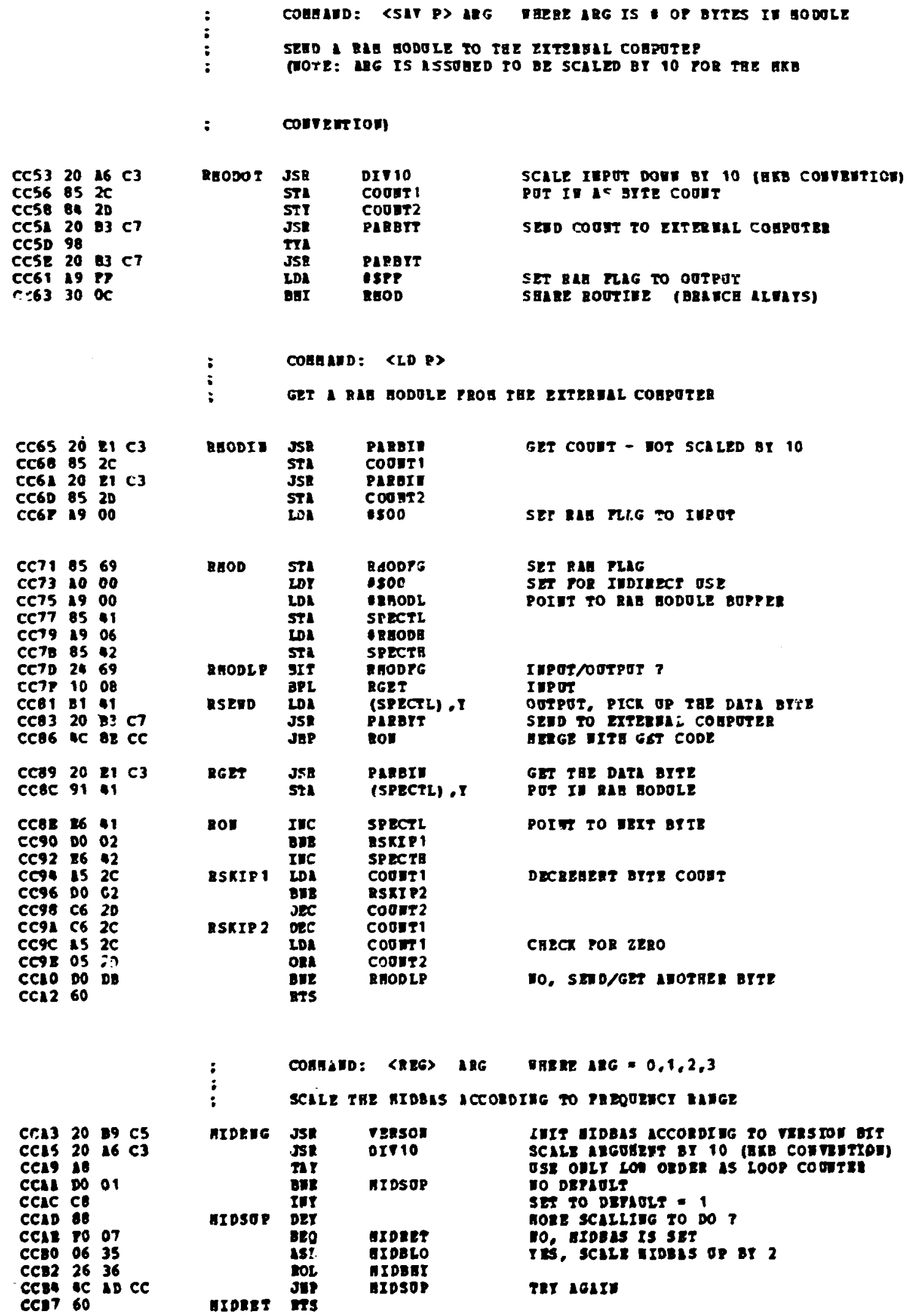




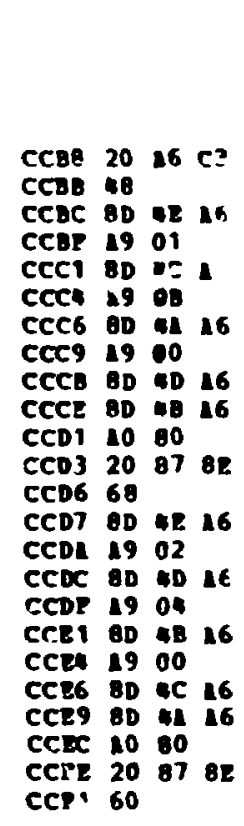

CCF2 $20 \backsim 6 \mathrm{c} 3$

CCP5 $\$ 8$

CCP6 BD 16

cCrs $10 \quad 80$

CCPB 2078 AC

CCPE 50 DC

oD00 68

CDO1 BD QE 16

CDO4 1080

Coos 2078 ec

c009 $00 \quad 02$

CDOB 60

cooc 68

CDOD $2068 \mathrm{C6}$

CD 1060

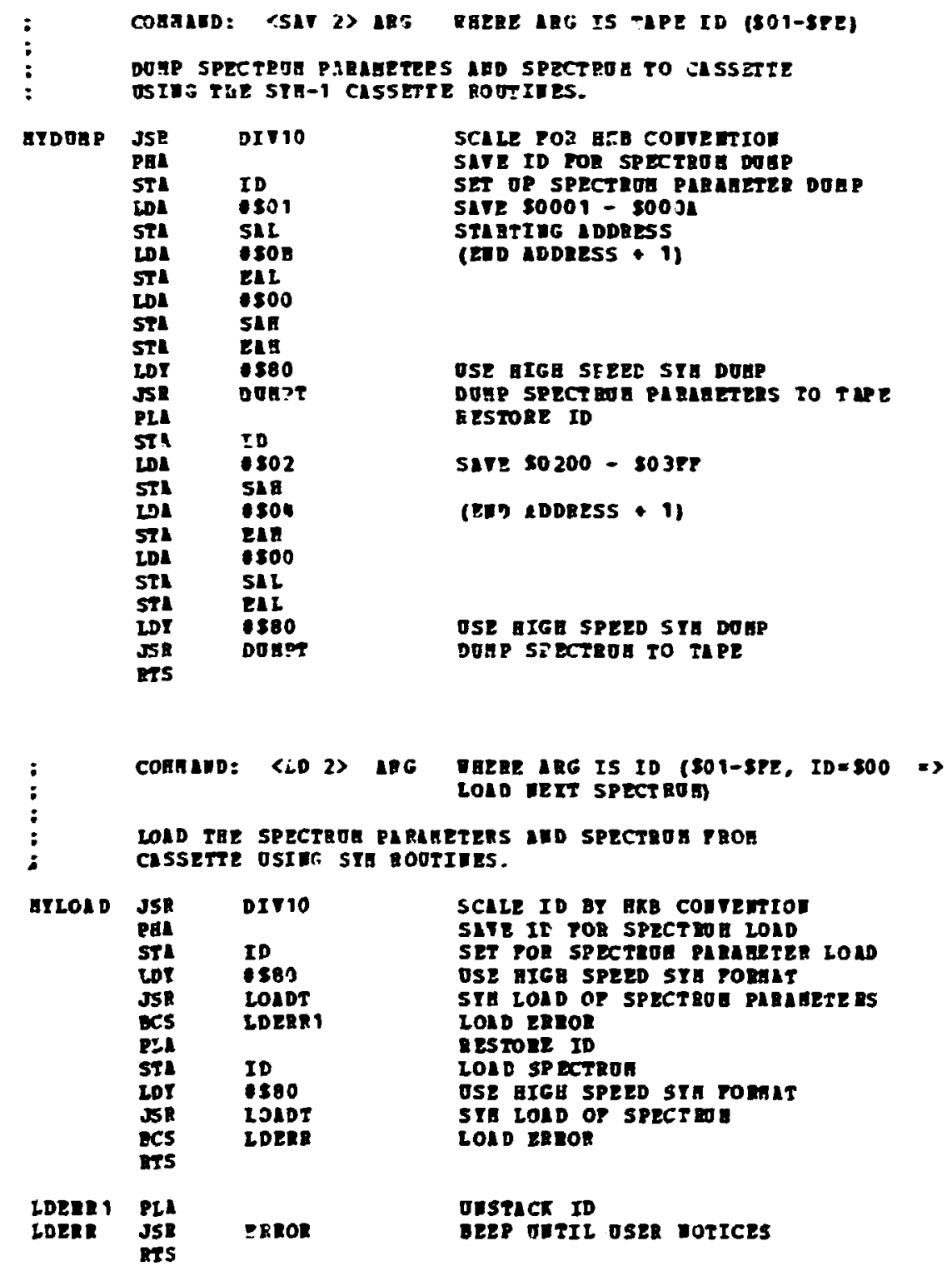


STadoL TABLE

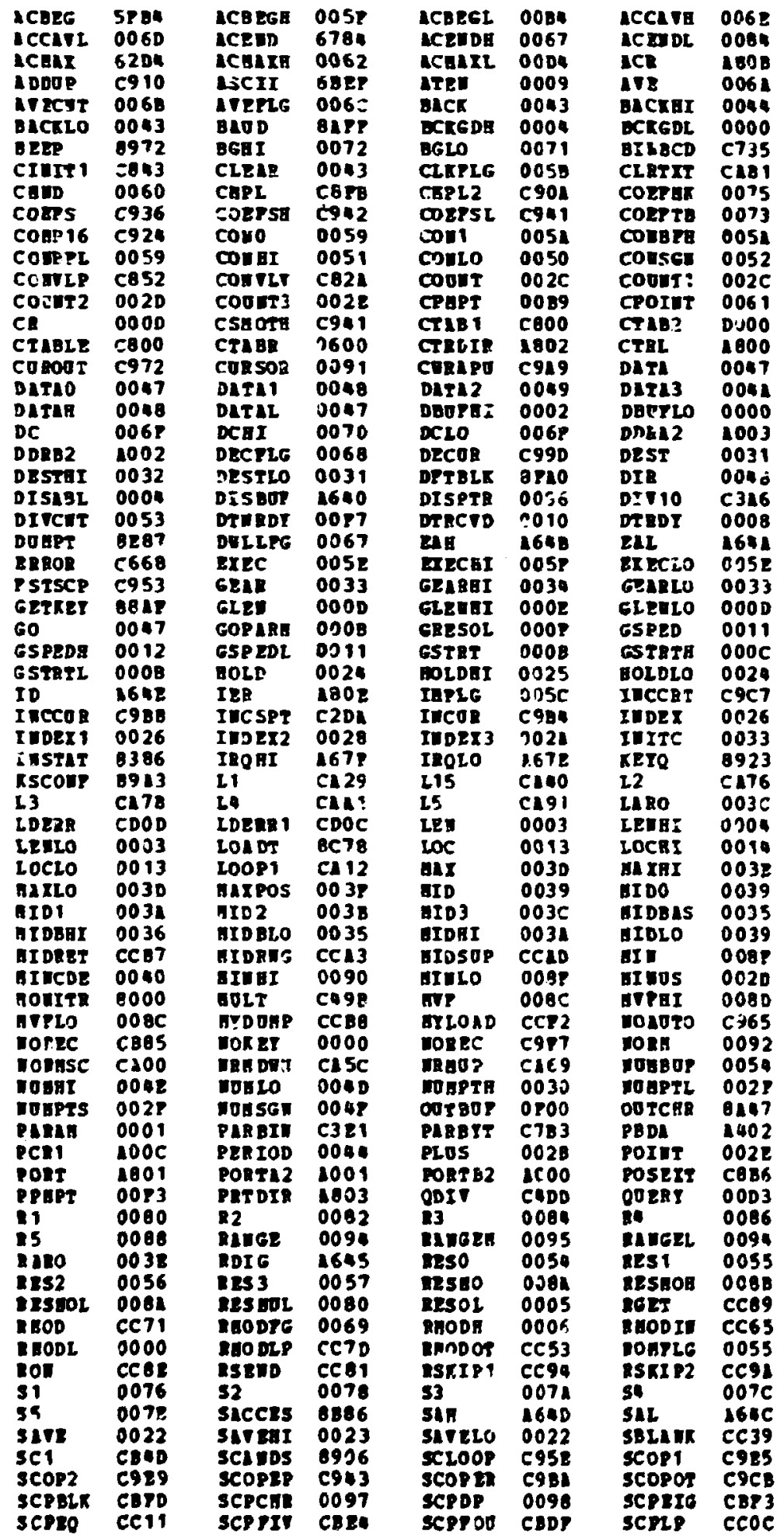




\begin{tabular}{|c|c|c|c|c|c|c|c|}
\hline 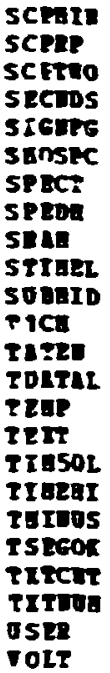 & 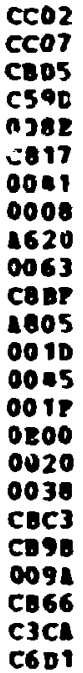 & 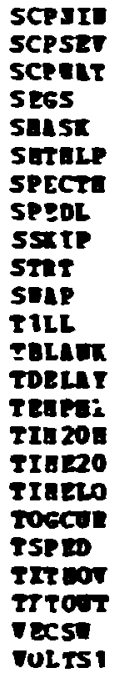 & 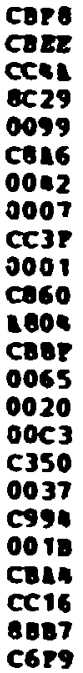 & 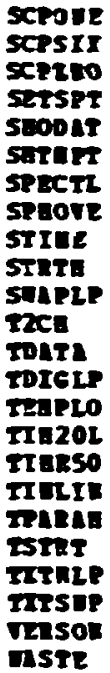 & 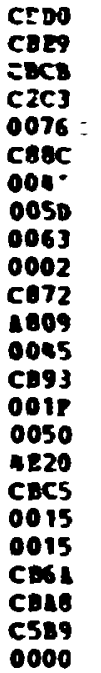 & 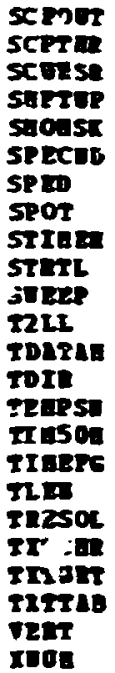 & 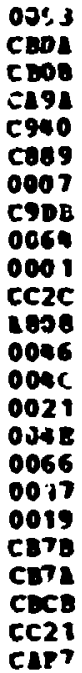 \\
\hline
\end{tabular}


Appendix C

ELECTRONIC SCHEATIC FOR DUTAS 
112 


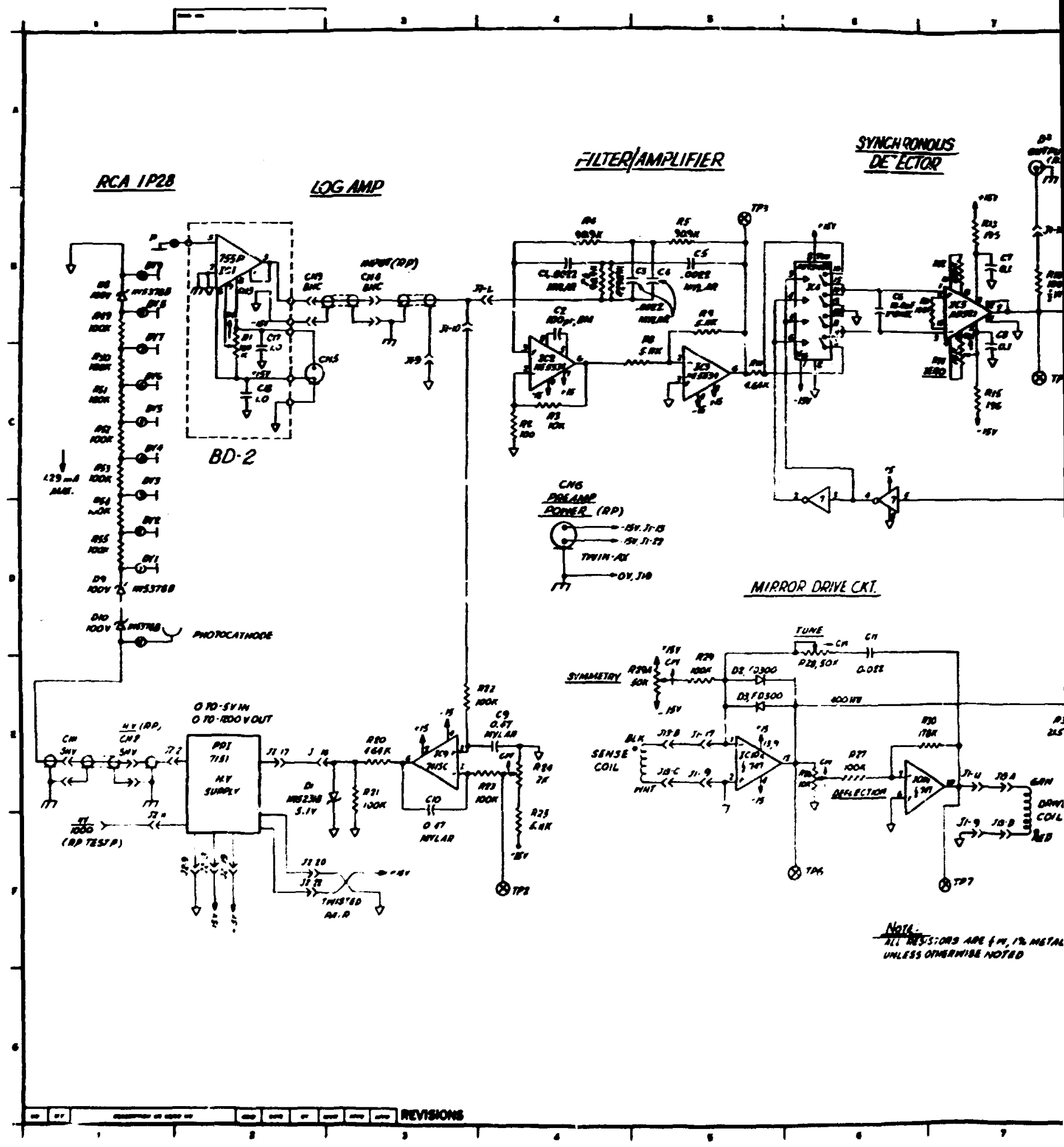





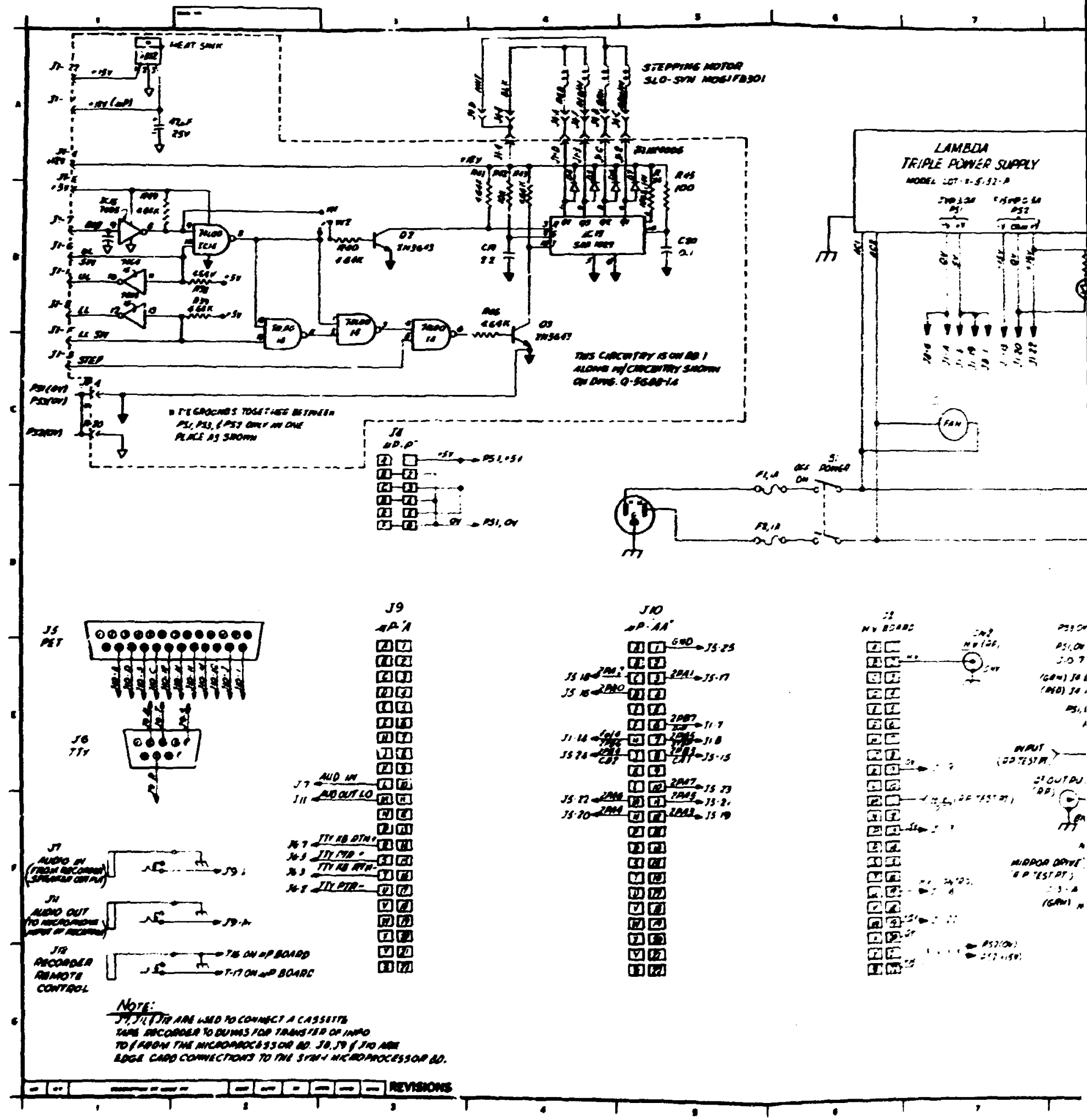




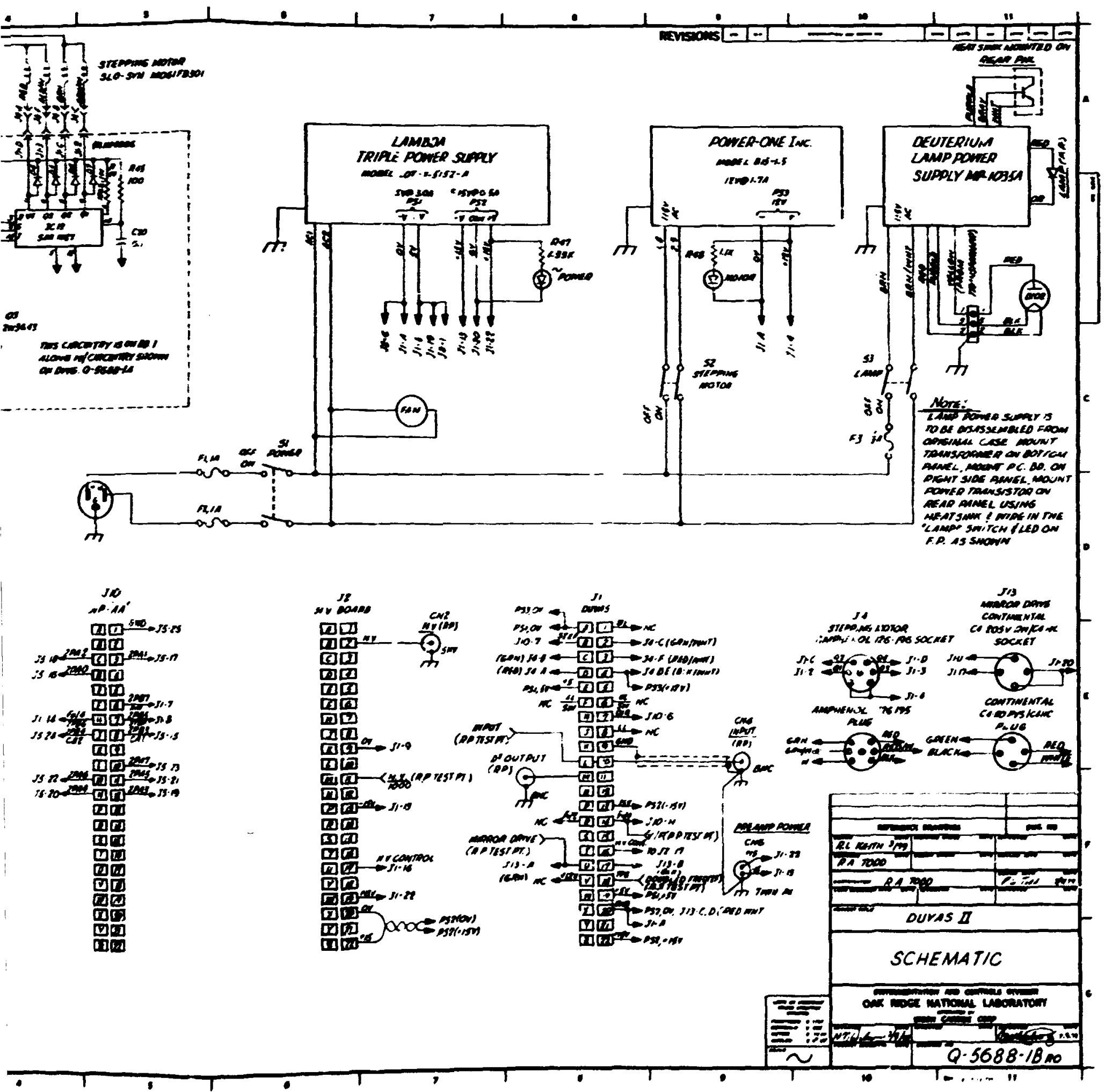


Appendix $D$

PAR IAL PARTS LIST FOR PROTOTYFE DUVAS 
Appendix D

'ARTIAL PARTS LIST FO' PROTOTYPE DUVAS

Oplical scanner, tant-jand trpe, $400 \mathrm{~Hz}$

Bulova Watch Company, Inc., Electronic Division, Type 150 (modified)

Monocrromator, $10 \mathrm{~cm}$, holographic grati: $\mathrm{g}$

J-Y Optical Systems, Model HIO UV-V (mn "ified)

High-voltage supply, plig-in card

Pacific Precision Instruments, Model 7151

Leuterin lamp ( $\mathrm{Ty}$ e $\mathrm{Di02}$ ) and power supply

McKee Pederson, Mc Jel MP-1035.1 (nodified)

Stepping mo or

Superior Flectric Co., SLO-SYN MO61FD301

Power supply, $12 \mathrm{Vdc}$ e 1.7 A

Power-One, inc., Model B15-1.5

Power supply, 5 Vdc @ $3 \mathrm{~A}, \pm 15 \mathrm{Vdc}$ a $0.5 \mathrm{~A}$

Lamh Ja Electronics Corp., Model iOT-X-5152

Photomultiplier tube, S-19 spectral response

EMI Co! ... Model 9783B

Single bourd computer wit: keypad and display, free EPROM sockets, Synertek Systems Corp., Model SYM-1

Assorted integrated circuits and electricai components - see drawings Appendix $C$. 